Old Dominion University

ODU Digital Commons

Educational Foundations \& Leadership Theses

\& Dissertations

Educational Foundations \& Leadership

Winter 2007

\title{
Generational Differences Among Community College Students in Their Evaluation of Academic Cheating
}

Kathleen E. Wotring

Old Dominion University

Follow this and additional works at: https://digitalcommons.odu.edu/efl_etds

Part of the Educational Assessment, Evaluation, and Research Commons, Educational Sociology Commons, and the Higher Education Commons

\section{Recommended Citation}

Wotring, Kathleen E.. "Generational Differences Among Community College Students in Their Evaluation of Academic Cheating" (2007). Doctor of Philosophy (PhD), Dissertation, Educational Foundations \& Leadership, Old Dominion University, DOI: 10.25777/rdax-r433

https://digitalcommons.odu.edu/efl_etds/195

This Dissertation is brought to you for free and open access by the Educational Foundations \& Leadership at ODU Digital Commons. It has been accepted for inclusion in Educational Foundations \& Leadership Theses \& Dissertations by an authorized administrator of ODU Digital Commons. For more information, please contact digitalcommons@odu.edu. 
GENERATIONAL DIFFERENCES AMONG COMMUNITY COLLEGE

STUDENTS IN

\section{THEIR EVALUATION OF ACADEMIC CHEATING}

by

Kathleen E. Wotring

B.S.N. May 1976, University of Florida

M.S.N. August 1978, University of Alabama in Birmingham

A Dissertation Submitted to the Faculty of Old Dominion University in Partial Fulfillment of the

Requirements for the Degree of

DOCTOR OF PHILOSOPHY

COMMUNITY COLLEGE LEADERSHIP

OLD DOMINION UNIVERSITY

December 2007

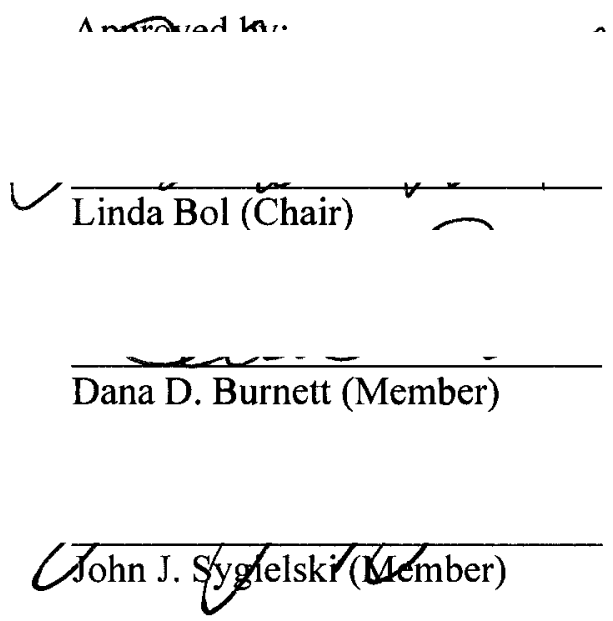




\title{
ABSTRACT \\ GENERATIONAL DIFFERENCES AMONG COMMUNITY COLLEGE STUDENTS IN \\ THEIR EVALUATION OF ACADEMIC CHEATING
}

\author{
Kathleen E. Wotring \\ Old Dominion University, 2007 \\ Chair: Dr. Linda Bol
}

Values development is an important part of the mission of community colleges, and upholding academic integrity is one way in which colleges advance this mission. Community colleges serve a multigenerational student body, more diverse than most four-year institutions of higher education, and different generational cohort groups hold different values and attitudes. The purpose of this study was to determine whether community college students varied by generation in their evaluation of academic activities as cheating, and to further determine whether such variation interacted with demographic variables and the extent to which personal morality is grounded in a religious belief system. Based on the literature, a Likert-type scale instrument was developed, the Definitions of Cheating Scale (DoCS). Following administration in a pilot study, the instrument was subjected to factor analysis and revised. The revised DoCS was completed by 650 students. Factor analysis was again conducted, resulting in four factors: exams/papers, fabrication, shortcuts, and excuses. The results supported the reliability and validity of the instrument. Results of MANOVA determined that students did not differ by generation in their evaluation of cheating related to exams and papers. However, significant differences did exist among generations in their evaluation of activities of fabrication, taking shortcuts, and 
making excuses, with Millennial students consistently rating activities less strongly as cheating than either Generation X or Baby Boomer students. None of the student characteristics measured were significant as main effects or in interaction with generation. These results are consistent with previous literature regarding generational differences in values and attitudes such as team orientation and achievement-pressure (Howe \& Strauss, 2000), and suggest that discussions with college students about academic honesty must be frank and deliberate. The DoCS also provides a potential measure for the effectiveness of activities designed to improve the climate of academic integrity on a college campus, such as implementation of an honor code.

\author{
Members of Committee: Dr. Dana Burnett \\ Dr. John Sygielski
}


Copyright, 2007, by Kathleen E. Wotring, All Rights Reserved. 


\section{ACKNOWLEDGMENTS}

To the faculty of the Community College Leadership program at Old Dominion University, my thanks not only for sharing your experience and wisdom, but for being part of the adventure of a initiating a new academic program that has helped me enormously in serving the students of my community college; special thanks for the classroom experiences provided by Dr. Dennis Gregory, Dr. Molly Duggan, Dr. John Presley, and Dr. Woody Schwitzer.

To the members of my committee, Dr. Dana Burnett and Dr. John "Ski" Sygielski, my appreciation for your unique perspectives which shaped a more comprehensive, and therefore useful, analysis and synthesis of the topic.

To the chair of my committee, Dr. Linda Bol, my gratitude that the zeitgeist resonated from the first consideration of the topic, and was sustained throughout the process. I look forward to sharing our work together with the larger academic community.

To the classmates who supported, challenged, critiqued and invigorated, not only in this work but throughout our cohort experience, my thanks and pledge of continued support as each completes the journey in turn.

To the community college colleagues who allowed access to their classes and reviewed evolving drafts of this document, my appreciation and pledge to return the considerations. To the student proctor, Jessica Kelly, who gathered data and became excited about this project, gratitude again, and best wishes for your future as a fellow educator. 
To my husband, Michael Reges, and my son, Matthew, whose cooking and construction in my absences for Teletechnet classes and Summer Institutes became legendary, and without whose support, both emotionally and concretely, this would not have happened, my deepest thanks.

And to the community college students, especially the Millennials, thank you for sharing yourselves. As epitomized in a bumper sticker celebrating a recent high school class graduation, "...Class of " 007 - the world is about to be shaken, not stirred." 
TABLE OF CONTENTS

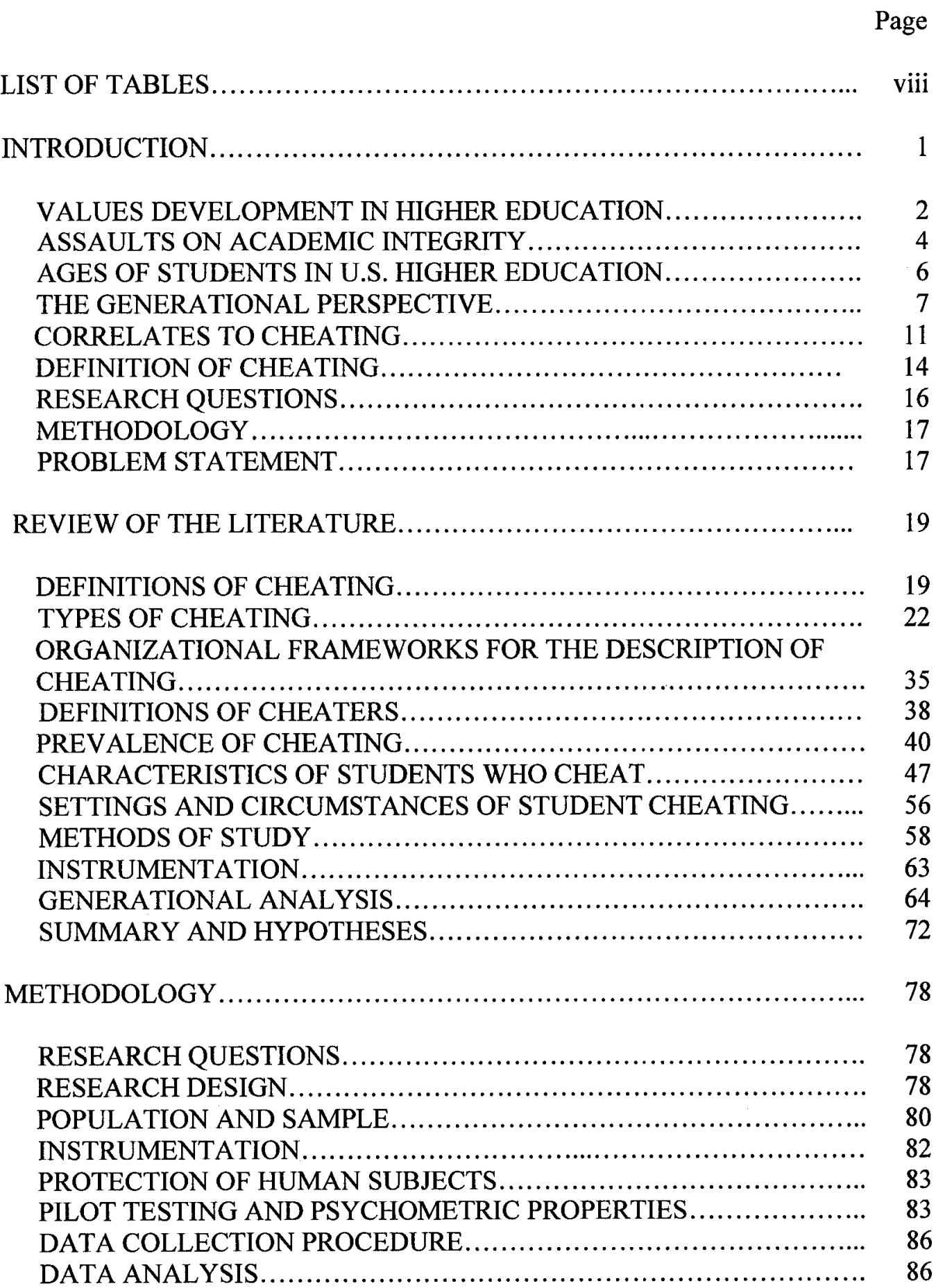




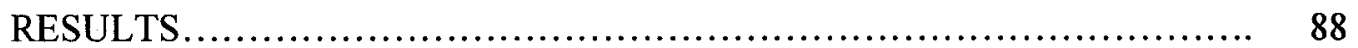

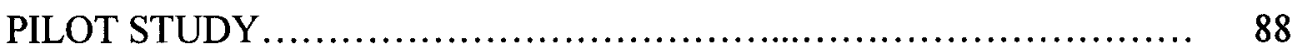

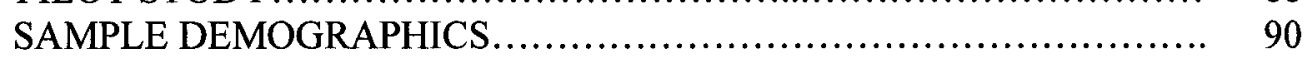

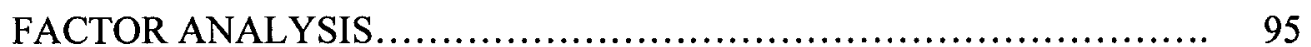

DESCRIPTIVE STATISTICS FOR DOCS RESPONSES .................. 97

RESULTS BY RESEARCH QUESTION.............................. 102

SUMMARY ................................................... 107

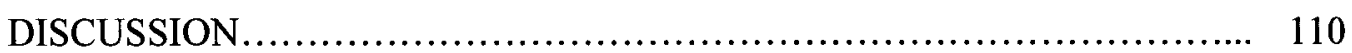

PURPOSE AND SIGNIFICANCE................................. 110

EFFECT OF GENERATIONAL MEMBERSHIP...................... 112

EFFECT OF DEMOGRAPHIC CHARACTERISTICS.................. 114

EFFECT OF PERSONAL MORALITY GROUNDED IN A RELIGIOUS

BELIEF SYSTEM.................................................. 117

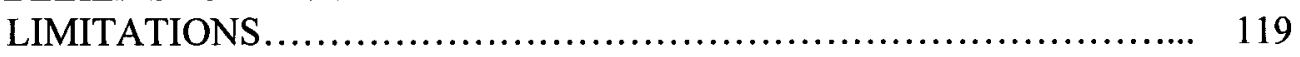

FUTURE RESEARCH AND PRACTICE ........................... 121

CONCLUSIONS.................................................... 126

REFERENCES.................................................... 129

APPENDICES.................................................... 148

SOURCES OF ACTIVITIES INCLUDED IN DEFINITIONS OF

CHEATING SCALE INSTRUMENT ................................. 149

SAMPLING MATRIX ............................................. 153

DEFINITIONS OF CHEATING SCALE - ORIGINAL VERSION....... 154

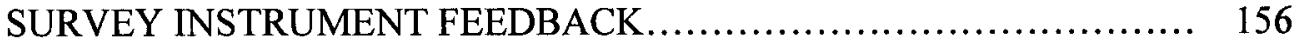

PROCTOR INTRODUCTION OF SURVEY TO CLASS -

PILOT STUDY ..................................................... 157

LETTER TO SURVEY PARTICIPANTS - PILOT STUDY .............. 159

ORIGINAL DOCS FACTOR ANALYSIS PATTERN MATRIX ........... 161

DEFINITIONS OF CHEATING SCALE - FINAL VERSION ........... 162

PROCTOR INTRODUCTION OF SURVEY TO CLASS.................. 164

LETTER TO SURVEY PARTICIPANTS ............................. 165

DOCS INSTRUMENT FACTOR ANALYSIS PATTERN MATRIX ...... 166

RETAINED DOCS ITEMS DESCRIPTIVE STATISTICS................ 167

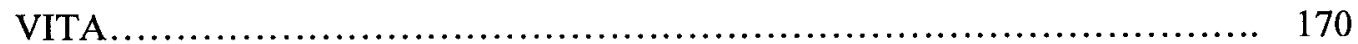




\section{LIST OF TABLES}

Table

Page

1. Study Variables............................................................ 79

2. Generational Distribution of VCCS Students Fall, 2005......................... 80

3. Blueprint for Construction of the Definitions of Cheating Scale.............. 83

4. Pilot Study Distribution by Generation and Program of Study................ 89

5. Sample Distribution by Generation.............................. 91

6. College Experience Distribution by Generation.................... 92

7. Gender Distribution by Generation................................ 92

8. Program of Study Distribution by Generation........................... 94

9. Personal Morality Grounded in a Religious Belief System

Response Distribution by Generation.............................. 95

10. Test-Retest Coefficients for DoCS Items Retained from Pilot Study..... 96

11. DoCS Scales Descriptive Statistics, All Scales....................... 97

12. DoCS Exams/Papers Scale Descriptive Statistics.......................... 98

13. DoCS Fabrication Scale Descriptive Statistics............................. 99

14. DoCS Shortcuts Scale Descriptive Statistics.......................... 100

15. DoCS Excuses Scale Descriptive Statistics............................. 102

16. Wilk's Lambda Values and Significance Levels by Research Question... 104

17. Descriptive Statistics and MANOVA Results for Cheating by Generation......................................................... 105

18. Summary of Research Question Findings.......................... 109

19. Generational Distribution of VCCS Students Fall, 2005 versus

Fall, 2006 


\section{CHAPTER I}

\section{Introduction}

"Seek first to understand..." (Covey, 1999, p. 235).

In order to serve effectively in higher education, leaders must understand the institution, its history and current place in society, its faculty and staff, its funding sources, its facilities and technologies. At the very core of the institution, however, are its students. The more deeply and richly college leaders understand their students' knowledge, skills, abilities, beliefs, and values, the better prepared they will be to promote and enhance their success. Understanding how students evaluate academic cheating is especially crucial, not only to the promotion of their success in their chosen disciplines of study, but also to the promotion of values development as part of the broader mission of higher education.

In this chapter, areas of the literature that shaped the origin of the research questions will be described. The historical significance of values development as part of higher education in the United States will be reviewed followed by a brief overview of assaults on academic integrity, both past and present. Then, the changes in age distribution among college students in the U.S. will be discussed. The generational perspective for the examination of changes in prevailing societal attitudes and values as presented by Strauss and Howe $(1991,1997)$ will be introduced, followed by an overview of variables which have been studied and correlated with student cheating. Finally, significant terms will be defined, research questions posed, and the study methodology introduced. 
Values Development in Higher Education

Values development has been part of the mission of higher education in the United States from its beginning. The first three colleges in the British colonies of America were founded as adjuncts to their respective churches: Harvard (Puritanism), William and Mary (Church of England) and Yale (Congregationalist); the founding documents of all three address the goal of educating ministers (Geiger, 1999). The curricula of these colleges closely followed that which had been established in Europe during the Middle Ages and traced back to Aristotle's trivium of ethics, metaphysics, and natural philosophy or science (Geiger). The primary goal of the curriculum (and in fact, of the entire college experience) was the development of a sense of moral responsibility and sound character, with resultant ethical thoughts and actions (McNeel, 1994). In 1736, the William and Mary College Statutes specifically addressed the importance of holding scholars to high standards of morals, truth and good manners (W\&M Undergraduate Honor Council, 2005). Colleges founded in Maryland, Georgia, South Carolina, North Carolina, Pennsylvania, and New York in the years shortly after the Revolutionary War coupled the values of a republican education, "instilling selflessness, patriotism, and virtues in the citizens of the new republic," with Enlightenment learning, where theology sought to accommodate the truths of science and reason (Geiger, p. 43).

Higher education in the U.S. continues the mission of values development today. Despite challenges during the rise of academic interdisciplinary specialization during the late $19^{\text {th }}$ and early $20^{\text {th }}$ centuries, a general or liberal education movement 
has persisted, and many professional schools have recently added specific courses of instruction in ethics to their programs of study (McNeel, 1994). Nadelson (2006) recently advocated that higher education should re-focus on values development, contending that educational programs that are concentrated on the practical arts, which have been increasing in numbers, have been producing graduates with more cognitive training and less development of character than in the past. According to Nadelson, "...fast track programs are not allowing time for reflection, the contemplation of 'big questions' about the meaning of life, and a mentoring environment to be fostered" (p. 1). The Center for Academic Integrity, based at Duke University, is a consortium of some 200 colleges and universities which promotes communication and the sharing of strategies aimed at advancing the values of honesty, trust, fairness, respect, and responsibility in higher education (CAI, 1999); the scope of activity and participation in this group demonstrates the continued importance of values development to educators in the United States.

Community colleges share in the values development mission of higher education, and faculties at community colleges have reported sharing the belief that they have a primary role in values education (Burke, 1997). Beginning with the founding of Joliet Junior College in 1901, public two-year colleges have contributed significantly to the responsiveness of higher education to community needs (AACC, n.d.). Defined by Cohen and Brawer (2003) as "any institution regionally accredited to award the associate in arts or the associate in science as its highest degree" (p. 5), community colleges now enroll $45 \%$ of U.S. undergraduate college students (AACC, 2007), and are recognized as "a central element in the fabric of American 
postsecondary education" (Cohen \& Brawer, p. 31). Over ninety percent of U.S. community colleges were found, in 1992 , to have academic integrity policies in place, and nearly ninety-eight percent had procedures for dealing with academic misconduct (Aaron, 1992).

Assaults on Academic Integrity

In an atmosphere of scholarly pursuits and moral enlightenment, what motivation could exist for the violation of academic integrity? Citing the Chinese Imperial examination system for access to lucrative government service positions, Jordan (2003) attributed the growth of academic cheating to the development of a link between education and economic opportunity. Open to commoners, this process served as a gateway to social and financial rewards based on demonstrated intellectual talent. Regulated through education, but unrelated to any fundamental purposes of education such as the pursuit of truth, this examination system became riddled with widespread cheating (Miyazaki, 1963). Although unable to locate supporting documentation from the time, Jordan argued that the honor code at the University of Virginia, requiring students to sign a statement with each examination certifying that they have not cheated, would not have been established in 1842 without proximate cause. Angell (2006) asserted that the escalation of college cheating to what he termed "epidemic proportions" has been driven by the increasingly greater emphasis

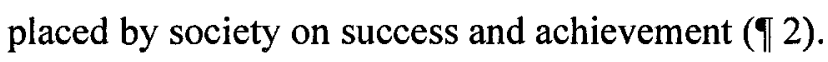

Formal research on academic cheating dates back to the early $20^{\text {th }}$ century, with the first studies centered in the disciplines of education and educational psychology (Crown \& Spiller, 1998). Writing on college cheating in 1941, Drake 
reported that there existed "already a rather large amount of literature on the subject" (p. 418). Major college cheating scandals have periodically gained national attention in the United States, such as that at the University of Virginia in 2002 where 48 students were dismissed from the school and the degrees of three graduates were revoked (“U.Va.," 2002), and the more recent episodes at Duke's business school (Young, 2007) and Ohio University's engineering school (Wasley, 2006, 2007). The issue remains one of current editorial interest (Malesic, 2006) and research, both among practicing educators (Hard, Conway, \& Moran, 2006) and graduate students (Saddlemire, 2005). Although research in community college settings has been sparse (Pascarella \& Terenzini, 1998), two-year college faculty have suspected (86\%) and been certain of (65\%) academic dishonesty in their classrooms (Burke, 1997).

Research findings have been inconsistent on the question of whether college cheating has actually increased in the U.S. over time, but some theories of sociology support the assertion of such an increase. In attempting to understand student cheating, Hutton (2006) proposed an analysis derived from economic theories of benefit/cost analysis, unobservable behavior, and social network analysis. She concluded that students cheat because the cost/benefit tradeoff favors cheating, with a very low probability of being caught and rare reporting by faculty, and that the same factors that have contributed to more and stronger relationships among college students have also contributed to increased cheating. These factors will be explored further in the review of literature on the generational perspective.

Cheating has taken a variety of forms and has demonstrated students' innovative use of emerging opportunities and tools over time. Crib sheets, or 
unauthorized notes, have developed from miniature Chinese books dating from the Sui dynasty, circa 600 A.D. (Miyazaki, 1963) to answers imbedded in today's graphing calculators ("Graphing calculator," n.d.). Files of past exams and term papers stored at the fraternity house have grown into websites for the trading or purchasing of papers (Anderson, 1999) and computer programs (Gomes, 2006). Even college transcripts have been electronically altered, enhancing the appearance of academic performance and salvaging credit from a failed course attempt - until, in at least one case, detection (La, 2005). Universities such as Kent State and Claremont have not only revoked degrees upon determination of student plagiarism, but have successfully defended these actions in court (Campbell, Swift \& Denton, 2000). Ages of Students in U.S. Higher Education

From colonial times through the first half of the twentieth century, higher education in the United States was designed only for those destined to be leaders in the ministry, education, or government (Kuh, 2001). The vast majority of U.S. students engaged in higher education ranged from 18 to 24 years of age until the mid-1900s (Miller, 2001).

The Servicemen's Readjustment Act of 1944 (commonly known as the GI Bill) dramatically changed who could attend college and for what purposes, and in 1948, the Truman Commission promoted the establishment of a network of public community-based colleges to serve local needs (AACC, n.d.). Enrollments doubled during both the 1950s and 1960s, and during the last half century, higher education in the U.S. has evolved from an elitist system to one of more nearly universal access (Kuh, 2001). 
While a great deal of recent college enrollment growth has been attributable to a population spike in 18 to 22 year-olds, the impact of older students' enrollments has not been insignificant. Analysis of information from the National Center for Education Statistics (NCES) demonstrated that from 1990 to 1999, enrollments of students over age 25 grew seven percent, compared with growth of eight percent for younger students; an increase of nine percent has been projected in the number of students over age twenty-five between 1999 and 2010 (Miller, 2001). "Even after subtracting graduate students [approximately $14 \%$ ] from the total college enrollment figures, there will still be a strong presence of older students in undergraduate classrooms over the next decade" (Miller, Projections, ๆ 2).

The American Association of Community Colleges reported the average age of community college students at 29 years in 2007 (AACC, 2007). More specifically, the Virginia Community College System (VCCS) reported that in the fall semester of 2005 , of students 18 years of age and older, $10.8 \%$ were ages 46 and older, $36.1 \%$ were ages 25 to 45 , and $53.1 \%$ were ages 18 to 24 (VCCS, 2006a). Community colleges serve a greater diversity of ages among their student populations than fouryear institutions, and are therefore more likely to confront generational differences among students. Older students report positive experiences at community colleges, and encourage others to join them (Kelch, 2006).

The Generational Perspective

William Strauss and Neil Howe have written extensively on the subject of variations and cycles in attitudes and values among members of different generations of people in the United States (Howe \& Strauss, 2000, 2003; Strauss \& Howe, 1991, 
1997). Defining a generation as "a cohort-group whose length approximates the span of a phase of life and whose boundaries are fixed by peer personality" (p. 60), Strauss and Howe's (1991) theory of generations proposed an age-location perspective on history, noting that major events impact individuals differently depending on their age or phase of life at the time, and that these effects persist through the remainder of their lives. As opposed to the notion of a universal life cycle, Strauss and Howe portrayed neighboring generations as living very different life cycles, based on their different age locations in history, or the phase of their lives during which social moments took place. Social moments were defined as periods lasting typically about ten years during which "people perceive that historic events are radically altering their social environment" (p. 71). These social moments occur on a regular cycle, about every 40 to 45 years, representing about two phases of the average human lifespan: youth, age 0-21; rising, age 22-43; midlife, age 44-65, and elder, age 66-87. Social moments were further described in two distinct types: "secular crises, when society focuses on reordering the outer world of institutions and public behavior; and spiritual awakenings, when society focuses on changing the inner world of values and private behavior" (Strauss \& Howe, 1991, p. 71). Secular crises have consistently alternated with spiritual awakenings in U.S. history.

Strauss and Howe (1991) went on to identify four generational types which have cycled in U.S. history with only one exception (a skipped generation at the time of the Civil War). These generations were defined based on their members' phase of life at the time of major social moments. 
Adaptive generations, over-protected children during secular crises such as the Great Depression, were noted for becoming risk-avoiding recessives in public life, ameliorators rather than pragmatists, and later influential but less respected, sensitive elders (Strauss \& Howe, 1991). The current living Adaptives are the Silent generation (youngest members now 64 years of age); comprising college enrollments too few to be reported separately, Adaptives will not be included in this study.

Idealist generations were raised as indulged youths following a secular crisis, rising into adulthood at a time of a spiritual awakening, becoming dominant in public life through redefining the inner world of values and culture, and later serving as visionary elders guiding the next secular crisis. Of the generations now populating U.S. community colleges, Boomers represent an Idealist generation, having experienced the spiritual awakening of the Consciousness Revolution (circa 19671980 ) as they rose to adulthood (Strauss \& Howe, 1991).

Reactive generations were children during these same spiritual awakenings, growing up under-protected and criticized, becoming recessive pragmatists in public life during a secular crisis, and later respected, but less influential, reclusive elders. Generation Xers represent a Reactive generation, having experienced the Consciousness Revolution spiritual awakening during their youths (Strauss \& Howe, 1991).

Civic generations were rising into adulthood at the time of a secular crisis, becoming dominant in public life through rebuilding the outer world of technology and institutions, and later busy elders in the face of the next spiritual awakening (Strauss \& Howe, 1991). The Millennials now graduating from high schools and 
attending colleges represent a civic generation, with the secular crisis of their rising adulthoods still uncertain. Some have argued that the events of September 11, 2001, fulfilled this role, while others have reserved judgment (Burling, 2001), and still others propose that the larger War on Terror is the true crisis (M. Reges, personal communication, September 16, 2006).

Donald McCabe, one of the leading researchers and writers on academic integrity issues in the United States today, has recognized the potential impact of the Millennials on the climates of colleges and universities. "This cohort of students is generally disenchanted by the personal and corporate excesses of the 1990s. Given proper support and leadership, the Millennials could play a significant role not only in transforming the ethical climate of schools and colleges, but the larger society as well" (McCabe \& Pavela, 2004, p. 12).

This study will use the definition of generation proposed by Strauss and Howe (1991): "a cohort-group whose length approximates the span of a phase of life and whose boundaries are fixed by peer personality" (p.60). This definition focuses on the experiences of the generational members rather than changes in birth rates or other statistical parameters commonly used by demographers.

Additionally, this study will use the names and designations for U.S. generations as later revised by these authors, including Silent (birth years 1925-1942), Boom (birth years 1943-1960), Generation or Gen X (birth years 1961-1981), and Millennial (birth years 1982-2000) (Howe \& Strauss, 2000). The generational perspective and characteristics of the generations comprising the current U.S. community college student body will be described further in Chapter II. 


\section{Correlates to Cheating}

Much of the research on academic cheating among college students has sought to determine correlations between cheating (often self-reported) and various student characteristics. Some of the characteristics that have been studied in relationship to academic cheating, such as membership in a Greek organization (Robinson, Amburgey, \& Swank, 2004) and on-campus residence (Smyth \& Davis, 2004), are generally not applicable to the community college setting. Among the most commonly studied, however, have been gender, college experience, and program of study, and some attention has also been given to religious involvement - all of which are clearly relevant to the community college setting.

College experience. Given that the focus of this study is not to describe students who are more likely than others to cheat in college, but to understand how today's students operationally define cheating, the literature on moral development and moral reasoning is also important to consider. In this body of research, studies have shown that among adult college students, levels of moral reasoning as measured by one of the most commonly accepted instruments, the Defining Issues Test (DIT), correlate strongly with college experience, or the number of college courses completed (Rest, 1994).

Used as part of a design to relate overall moral development with specific attitudes towards academic dishonesty, the DIT showed that attitudes towards cheating were more powerful in predicting cheating behaviors than were demographic variables such as gender or major course of study (Bernardi et al., 2004). Obviously, for some students, a significant positive correlation exists between the extent of their college 
experience and their generational cohort membership. Therefore, college experience has been identified as an important factor to include in this study attempting to understand the influence of generational membership on students' perceptions of cheating.

Gender. Gender has been the student characteristic most commonly studied in correlation with college student cheating. Men have historically been shown to cheat more often than women (Roberts, Anderson \& Yanish, 1997), and in some recent studies, this finding persists (Dawkins, 2004; Rettinger, Jordan \& Peschiera, 2004; Vowell \& Chen, 2004). In a 1998 meta-analysis, Whitley found that males, by selfreports, cheated more often than females, but that the effect size was small $(d=.22)$, and that the gender differences in actual observed cheating were not significant. Whitely suggested that men may have been more willing than women to admit to cheating, perhaps feeling less guilt.

While some recent studies have continued to find men cheating more than women (Dawkins, 2004; Rettinger et al., 2004; Vowell \& Chen, 2004), the relationship of gender to cheating has changed over time. Crown and Spiller's (1998) meta-analysis found that studies conducted prior to 1972 reported males cheating more than females, but that this relationship changed over the subsequent 20 years, with a prevalence of non-significant relationships in the last 10 years. Gender has either not been significant, or had a correlation with cheating deemed by the researcher too weak to report, in a number of recent studies (Carpenter, Harding, Montgomery, \& Steneck, 2002; Jordan, 2001; Kerkvliet \& Sigmund, 1999). 
Program of study. Various studies have examined academic cheating among students within a particular discipline or program of study, such as business and economics (Nowell \& Laufer, 1997), marketing and management (Smith, Davy, \& Easterling, 2004), and nursing (Brown, 2002; Gaberson, 1997). The potential relationship between academic disciplines and certain behavior patterns has been recognized as high-profile cheating incidents have been analyzed in the context of the program of study involved; The Chronicle of Higher Education report on Duke University's business school incident noted that "...it is possible that business schools, by the very nature of the material they teach, breed a certain amount of academic dishonesty." (Young, 2007, ๆ 11).

A few studies have compared cheating, or attitudes about cheating, among students in different programs of study, and in some, such differences have been found. For example, business majors' were more likely to consider cheating to be socially acceptable than non-business majors (Smyth \& Davis, 2004). Cheating among criminal justice majors, compared with non-criminal justice majors, was more strongly influenced by the cheating behaviors of their friends, while non-criminal justice majors were more strongly influenced by their moral beliefs (Tibbits, 1998). Others, however, have not found differences in cheating (Jordan, 2001) or in moral judgment (Derryberry, Snyder, Wilson, \& Barger, 2006) based on academic major groups.

Personal morality and religious involvement. Fewer studies have examined aspects of students' relationships with religious belief systems as related to their attitudes or behaviors in academic cheating. As described above, Tibbits (1998) found 
non-criminal justice majors more strongly influenced about cheating by their moral beliefs than criminal justice majors, but the connection, if any, to a religious belief system was not explored.

Sutton and Hubs (1995) included level of religious involvement among the student characteristics they correlated with perceptions of academic dishonesty, and found that students with the highest levels of religious involvement were more likely than those in the lowest group to agree that "cheating is never justified under any circumstances." However, Vowell and Chen (2004), in comparing the predictive value for academic cheating of four alternate theoretical models, found that the model including religious activities did not prove the most powerful.

\section{Definition of Cheating}

Because it is central to this study, the term cheating requires specific definition. Variations in definitions of cheating were cited in a U.S. Department of Education report on academic dishonesty in 1993 (Maramack \& Maline), and lack of precision in terminology will be shown in the review of the literature to be a significant limitation in understanding both changes in attitudes over time and the current status of students' academic behaviors.

Among some writers, the term cheating is specifically used to refer to a relatively narrow set of behaviors focused on the enhancement of performance on an examination, test, or quiz. In this way, cheating is differentiated from other forms of academic dishonesty such as plagiarism, fabrication, and facilitating academic dishonesty (Gehring \& Pavela, 1994; Hollinger \& Lanza-Kaduce, 1996). 
Others, however, have recognized the more global connotation of cheating, as expressed by Dalton (1998): "cheating is a term that refers to a wide variety of behaviors that are regarded as unethical" (p. 5). One of the several definitions of cheat given by Merriam-Webster Online (n.d.) succinctly captures the full range of behaviors that are commonly classified as academic cheating: "to practice fraud or trickery." Many writers who have begun their research reports or editorial pieces using the term academic dishonesty have quickly shifted to the term cheating, or proceeded throughout their works to use the terms interchangeably (Petress, 2003; Pulvers \& Diekhoff, 1999; Roth \& McCabe, 1995). In discussing cheating among community college students, Moeck (2002) cast cheating broadly, to include plagiarism, other forms of taking credit for less-than-original work, and helping others to cheat. Smyth and Davis (2003) credited their definition of cheating as having been originated by Prescot (1989): "fraudulent behavior involving some form of deception in which ones' own efforts or the efforts of others are misrepresented," although Prescot actually used this definition to apply to the term academic misconduct (Prescot, 1989, p. 284). Nonetheless, this definition captures the wide range of behaviors with which faculty and educational administrators have been confronted, in language with which students can relate. In order to clarify the academic context associated with cheating, this definition will be modified slightly for use in this study; cheating will be defined as fraudulent behavior involving some form of deception in which one's own academic efforts or the academic efforts of others are misrepresented. 
Research Questions

Community colleges now more than ever serve a multigenerational student body. In fact, because their student body is so much more diverse than most four-year institutions, community colleges are the ideal setting in which to examine generational differences among students.

Because of their phases of life during significant social moments in our society, the personalities, values, and attitudes of Boomers, Generation Xers, and Millennials are cast quite differently, and community college leaders must understand these differences in order to best promote success for all students. As community college leaders seek to continue the tradition of academic integrity among this diverse student body, it is imperative that they understand how different attitudes and values may have created different operational definitions of what is considered cheating in the completion of instructional assignments and assessments. To this end, the following research questions were proposed:

1. Do community college students differ by generation (Boomer, Generation X, and Millennial) in their evaluation of academic activities as cheating?

2. Does the generational difference among community college students in their evaluation of academic activities as cheating vary with college experience?

3. Does the gender difference among community college students in their evaluation of academic activities as cheating vary with generation?

4. Do community college students differ by program of study in their evaluation of academic activities as cheating? 
5. Does the generational difference among community college students in their evaluation of academic activities as cheating vary with the extent to which their personal morality is grounded in a religious belief system?

\section{Methodology}

This study utilized a non-experimental comparative design. A questionnaire was developed by the researcher based upon the literature to measure students' evaluations of selected activities as cheating. This instrument provided scale scores for several types of cheating activities. Pilot testing was conducted in order to estimate reliability and validity of the instrument.

Purposeful cluster sampling was used to gather responses from a sample that included a diversity of students in terms of generations, gender, and college experience. Students' responses on each type of cheating scale were analyzed in a factorial design with three levels of generation, three levels of college experience, two levels of gender, four levels of program of study, and four levels of the extent to which personal morality is grounded in a religious belief system. This analysis investigated differences among scale scores by generation, and any interactions with student characteristic variables.

\section{Problem Statement}

Cheating among college students has been studied extensively in the United States, although little of this research has focused on the community college student body, which now represents $45 \%$ of undergraduate college enrollment (AACC, 2007). This study examined how cheating is defined among today's community college students. While previous studies have demonstrated that college faculty and students 
disagree about which behaviors constitute cheating (Higbee \& Thomas, 2002), authors have argued that such differences may be largely rooted in the differences in their roles. However, other forces may also be involved. Based on descriptions of significant differences among generations in values, attitudes, and patterns of behavior (Howe \& Strauss, 2000, 2003; Strauss \& Howe, 1991,1997), this study examined differences among the generations of students currently enrolled at U.S. community colleges in the activities that they evaluate as cheating. 


\section{CHAPTER II}

\section{Review of the Literature}

This literature review will begin with the various ways in which cheating has been defined, followed by a description of various types of cheating and organizational frameworks used to discuss cheating. Next, a range of definitions of cheaters will be described. Then, reports of the prevalence of cheating, characteristics of students who cheat and other variables that have been correlated with cheating will be summarized, followed by the methodologies that have been used in the study of cheating. Finally, the framework of generational analysis will be described.

The literature reviewed for this study was limited to studies examining students at the undergraduate college level, excluding studies of graduate, secondary and primary school students. Although the problem of cheating has been reported internationally, the confounding issues of differences in structures and systems of higher education, as well as differences in culture and historical influences around the world are beyond the scope of this study. Therefore, the literature reviewed was further limited to studies conducted in the United States.

\section{Definitions of Cheating}

Writers and researchers have used the terms academic integrity, academic dishonesty, and cheating inconsistently and often imprecisely. "One of the main issues that emerges from the literature relates to inconsistencies in the definition of academically dishonest behaviors and the lack of consensus and general understanding of academic dishonesty among all members of the campus community" (Pincus \& 
Schmelkin, 2003, $\uparrow 2$ ). Clarity of definition is especially crucial in this study which seeks to understand how students evaluate behaviors as cheating.

Academic integrity has been defined by the Center for Academic Integrity based at Duke University as "a commitment, even in the face of adversity, to five fundamental values: honesty, trust, fairness, respect, and responsibility. From these values flow principles of behavior that enable academic communities to translate ideals into actions" (1999, p. 4). Thus, academic integrity is the larger, umbrella concept under which a variety of behaviors can be categorized.

Similarly, academic dishonesty has been defined as "an intentional act of fraud, in which a student seeks to claim credit for the work or efforts of another without authorization, or uses unauthorized materials or fabricated information in any academic exercise (Gehring \& Pavela, 1994, pp. 5-6). Academic dishonesty, defined in this way, includes the forgery of academic documents, intentional obstruction or damage to the academic work of others, and assisting other students in committing acts of academic dishonesty.

The University of California at Irvine (1992) academic dishonesty policy distinguished among cheating (defined as copying from others during an examination or using notes during an exam) from dishonest conduct (defined as stealing an exam or answer key from an instructor, or changing academic records without sanction), plagiarism (defined as passing off another's work as one's own, or failure to credit creative productions), and collusion (defined as knowingly or intentionally helping another to cheat or plagiarize). This organizational framework is similar to that posed by Gehring and Pavela (1994) which distinguished among cheating (using 
unauthorized aids), fabrication (invention of information or citations), facilitating academic dishonesty (intentionally helping another to commit academic dishonesty), and plagiarism (representing the words of another as one's own). While this organizational framework is helpful in understanding specific activities, the limitation of cheating to the narrow behavioral range of exam misconduct does not reflect the common usage of the term.

Far more common both in the research literature and in nonscientific news reports is the broader use of the term cheating to encompass all acts of academic dishonesty, both in the research literature (Angell, 2006; Bernardi et al., 2004; Brown, 2002; Bunn, Caudill \& Gropper, 1992; Carpenter et al., 2002; Crown \& Spiller, 1998; Dawkins, 2004; DePalma, Madey \& Bornschein, 1995; Diekhoff et al., 1996; Drake, 1941; Graham, Monday, O’Brien \& Steffen, 1994; Higbee \& Thomas, 2002; Kerkvliet \& Sigmund, 1999; Whitley, 1998), and in nonscientific news reports (Clough, 2002; Kleiner \& Lord, 1999; Paul, 2004). This broader concept of cheating, encompassing all acts of academic dishonesty, will be used in this study.

Embracing this broader concept of the term, Smyth and Davis (2003) used the definition of cheating they attributed to Prescot (1989): "fraudulent behavior involving some form of deception in which ones' own efforts or the efforts of others are misrepresented" (Prescot, 1989, p. 284), although Prescot actually used this definition to apply to the term academic misconduct. In order to maintain focus on the academic setting and nature of behaviors under consideration, Prescot's definition will be adapted to define cheating in this study as fraudulent behavior involving some form of 
deception in which one's own academic efforts or the academic efforts of others are misrepresented.

Types of Cheating

Wide variation has existed in the literature in the activities specified when discussing or researching cheating. In some cases, authors have clearly focused on certain specific behaviors, such as theft of a copy of an exam (Bernardi et al., 2004) or changing answers during self-grading of an exam (Ward, 1987), while others have been interested in a wide variety of behaviors (Carpenter et al., 2002; McCabe \& Bowers, 1994; Sutton \& Hubs, 1995). Although the focus of this study will be to examine how current students evaluate specific activities in regard to cheating, the development of the instrument will be grounded in the types of cheating that have been reported both in the research literature and in news or anecdotal accounts.

Some activities, such as copying from another student during an exam, have been included in numerous studies on cheating. Others, such as falsely claiming to have handed in an assignment, have been noted in a single report. An example of the frequency with which certain activities have been included in reports on cheating is shown in Appendix A. In most studies asking students to report about their own behaviors or their observations of peers, the inclusion of an activity in the list has implied the author's categorization of the activity as cheating.

A few studies, however, have provided the opportunity to clarify respondents' determinations of whether a specific activity constituted cheating. In 1984, Nuss compared student and faculty ratings of the severity of specific cheating activities. She found general agreement on which activities were considered most serious and 
least serious, but also received comments from some faculty members who disagreed with the categorization of working together on homework as cheating, reporting they encouraged such group work (Nuss). Higbee and Thomas (2002) listed 25 activities less commonly studied as cheating, such as including an article in a reference list having only read the abstract, and watching videotaped films of famous works of fiction rather than reading an assigned book. Faculty and students were asked to rate each activity as it represented cheating: yes, no, or it depends. Significant disagreements were found in ratings not only between faculty and students on many items, but also among faculty and among students (Higbee \& Thomas). Several other surveys have assessed both students' reports of cheating behaviors and their classifications of those behaviors as cheating (Angell, 2006; Carpenter et al., 2002; Harding, 2001).

Cheating on exams, test, or quizzes. The common element in this category of cheating activities is the academic assessment exercise of a student responding, usually in writing, to questions from the instructor, also usually in writing, about course material that is expected to have been learned. These academic assessment exercises often contribute the greatest percentage (compared to other graded course activities) to a student's course grade, and cheating on them has been rated by faculty as the most severe form of cheating (Graham, 1994).

One distinct advantage in preparing for many exams is to know exactly what questions will be asked, so to access a copy of a test prior to the exam session is one strategy for cheating. Copies of tests have been stolen from faculty offices, obtained from students working in the college copying center, or from students or accomplices 
carrying a copy of the exam out of an earlier testing session (Cizek, 1999); faculty at the University of Florida reported a student who crawled through the air conditioning ducts to steal an exam from an instructor's office (Pactor, McKeen \& Morris, 1990). In the days prior to photocopy technology for the duplication of exam materials, one student acknowledged rummaging through college trash dumpsters after dark in search of the ditto masters for final exams, and reported finding at least one (LaBeff, Clark, Haines \& Diekhoff, 1990).

Another approach to exam cheating is to simply copy another's answers during the test. Strategically sitting near another student (Brown, 2002), making use of what one student described as his "incredibly gifted eyes" which allowed him to see test papers of students four rows in front of him (LaBeff et al., 1990, p. 190), sitting near an experienced student not enrolled in the current class (Cizek, 1999), and trading papers during the test (Davis, Grover, Becker \& McGregor, 1992) have all been reported as variations in copying answers during exams.

Where multiple sections of a class meet at different times to take the same test, advantage can be gained by asking a fellow student about questions on the exam $\mathrm{s} / \mathrm{he}$ has taken earlier (Cizek, 1999). Among engineering students, $31.7 \%$ reported asking fellow students about test questions once or twice while in college, and another $38.1 \%$ reported asking three or more times (Carpenter et al., 2002). This strategy can be enhanced by creating extra time to talk with fellow students, such as by delaying taking an exam.

Delayed taking of an exam with a falsified excuse (e.g., the death of a grandparent, personal illness, etc.) may provide additional opportunity for the 
questioning of fellow students about the content of the exam, as well as additional time for study. Combining delayed taking of tests and submission of papers, $22.3 \%$ of engineering students acknowledged such activities once or twice, and $6.5 \%$ more acknowledged such delay tactics three or more times while in college (Carpenter et al., 2002). Using a similar combination of delayed tests with delayed papers, performing and visual arts students reported the greatest use of these strategies $(52.9 \%)$, followed by arts and sciences students (35.3\%), business students (28.1\%), and health and human services students (23.9\%) (Roberts, Anderson \& Yanish, 1997).

One study reported a student secretly tape-recording the class test review, and then passing the tape to the student preparing for a make-up test (Brown, 2002). In some cases, the circumstances under which make-up exams are given may also allow for other forms of cheating with less risk of detection, such as the use of unapproved notes (Cizek, 1999).

Such notes, sometimes known as crib sheets, take many forms. Notes have been found on the undersides of ball-cap brims, on shoes, on the back of calculators, on tiny rolled-up papers hidden in the cap of a pen (LaBeff et al., 1990), on body parts (Brown, 2002), and on paper flowers made for exam day and worn as jewelry on students' clothing (Davis et al., 1992). Others, as reported by faculty during a recent conference, have found crib sheets on the inside of water bottle labels, fast-food restaurant sandwich wrappers, and on various body parts of students for use by self and others, such as the back of the neck of the student seated to the front of another (Unidentified personal communications, April 7, 2006). A variation in the written crib sheet was reported by a student who tape recorded the answers before the test 
(undisclosed how the answers were obtained), and "just took [the] Walkman to class and listened to the answers during the test" (Davis et. al., 1992, p. 18). Among engineering students, $21.6 \%$ reported using unapproved notes during one or two exams while in college; $6 \%$ reported such activity three or more times (Carpenter et al., 2002).

When tests or quizzes are returned for review, students may alter their responses and then claim that an error has been made in grading the exam (Cizek, 1999). A variation of this technique, alteration of answers on a quiz returned to students for self-grading, was used in an early study for direct observation of cheating, and $24 \%$ of students took advantage of at least one out of six such opportunities to alter their grades (Drake, 1941). Among business and accounting students, $23 \%$ were found to cheat in a similar manner (Nowell \& Laufer, 1997).

Cheating on homework, lab reports, and assignments. Submitting an assignment originally completed for a previous class, or recycling, has been reported by science lab students (DelCarlo \& Bodner, 2004). Given that assignments are generally more class-specific than term papers, most students probably encounter fewer opportunities for this type of cheating than other types. A major group who can, and do, use this strategy, however, are nursing and other health professions students, who may submit the same, or only slightly altered, assignment regarding a patient with a medical condition one semester that was originally written about a different patient with a similar condition in a prior semester (Bailey, 2001). 
Falsely claiming to have handed in an assignment is a delay strategy that is particularly effective in large classes conducted by instructors who have demonstrated unorganized or hurried management of paperwork. The cleverest students take care, upon discovery of the missing status of the work, to submit a photocopy of the original which they report routinely maintaining in case of just such mishaps. Among engineering students, $5.4 \%$ reported employing such false claims once or twice in their college careers, while another $0.9 \%$ reported using this strategy three or more times (Carpenter et al., 2002).

Working in groups on homework, lab reports, or other assignments is one of the activities more commonly debated as to whether it represents cheating. As reported by one student, "You're working on it and they're working on it and I mean, it's kind of like their work is your work, more like a team environment" (DelCarlo \& Bodner, 2004, p. 57). Engineering students reported that, when no class policy existed about working in groups, $18.6 \%$ did so once or twice, and another $63.4 \%$ did so three or more times (Carpenter et al., 2002). Business students reported the highest prevalence of working on homework with others when the instructor expected independent work (71.9\%), followed by students in arts and sciences $(53.5 \%)$, health and human services (46.7\%), and performing and visual arts (41.2\%) (Roberts et al., 1997). Some of the discordance over group work may be exacerbated by the cultural expectations of some international students in U.S. colleges regarding the liberal giving and taking of significant help from family members or friends of the family on homework and assignments (Cole \& McCabe, 1996). 
Actually copying homework, lab reports, or other assignments from other students, however, was readily distinguished by science students from group work, and more often classified as cheating (DelCarlo \& Bodner, 2004). This is one type of cheating which has been reported more often by students who belong to fraternities or sororities than by those who do not (Whitley, 1998). Among engineering students, $33.7 \%$ reported copying assignments once or twice while in college, and another 23.5\% copied assignments three or more times (Carpenter et al., 2002). Copying another's homework with the knowledge of the author was reported most often by business students $(55.1 \%)$, followed by students in arts and sciences $(51.2 \%)$, performing and visual arts (41.2\%), and health and human services (37\%) (Roberts et al, 1997).

Changing or creating data for homework, lab reports, or assignments has also been reported by science lab students (DelCarlo \& Bodner, 2004) and by nursing students (Brown, 2002). Such activities in the science laboratory, not limited to students, were documented in 1830 by Charles Babbage in his Reflections on the Decline of Science in England. Babbage differentiated between a hoax and a forgery - a hoax being intended to be discovered, usually played "on scientific academies which had reached the period of dotage" (p.176), whereas the deception of a forgery was intended to last forever; he also described two methods of presenting more convincing data, trimming (the selective averaging of observations which vary most and least from the mean) and cooking (the selective inclusion for analysis only those observations supportive of a hypothesis) (Babbage). 
Just as some delay taking a test with a false excuse, students may delay turning in homework, lab reports, or other assignments with falsified tales of tragedy. From the website MyExcusedAbsence.com (n.d.), templates for various physician's notes, funeral service programs, and jury service documents can be purchased for $\$ 24.95$.

Cheating on papers. Submitting a paper originally written for a previous class is another form of academic recycling, one that generated substantial disparity of responses among both students and faculty as to whether or not it constituted cheating. Some faculty maintained that this practice was no less ethical than the generation of several publications from one piece of research, while others considered it blatantly fraudulent (Higbee \& Thomas, 2002). Combining lab reports with term papers, $27.7 \%$ of engineering students reported recycling once or twice while in college, and another $14.6 \%$ reported doing so three or more times (Carpenter et al., 2002).

Copying from a book or website without proper citation is one of the longeststanding approaches to cheating on papers. One professor noted on a student's paper: "This is superior work... It was superior when Saint Thomas Aquinas wrote it, just as it is today. Saint Thomas gets an A. You get an F" (Alschuler \& Blimling, 1995). Reflecting on the message to faculty in students' plagiarism, Kraus (2002) argued that "a rapidly growing number [of students] simply do not see plagiarism as wrong in the ways that my colleagues and I assume they do. They recognize that they should not do it, but they understand our concern over it as an almost quaint prohibition" (Section I, ๆ 9). Further complicating the understanding of proper or improper use of another's work can be the culturally-instilled value of some international students in U.S. colleges that one gives honor to another's work by incorporating it into one's own, not 
necessarily including what would be considered proper citation according to U.S. academic standards (Cole \& McCabe, 1996).

Submitting a paper that has been purchased from another student or from a commercial firm has received considerable public attention as a form of cheating. One graduating international student in Washington, D.C., reportedly introduced a new student from his homeland to the ways of the university with the advice that he had purchased all of his papers for college, including his honors thesis (Alschuler \& Blimling, 1995). Popular magazines, such as Rolling Stone, have carried advertising from businesses such as Research Assistance, offering a 306-page catalog of 15,778 pre-written term papers and a toll-free phone number to call for a quote on a customwritten paper, and more than 100 web-sites have been cataloged posting at least 25 term papers and promoting the downloading of them (Anderson, 1999). Combining paying for papers with paying someone to take an exam, $21.7 \%$ of engineering students reported purchased-cheating once or twice during their college careers, and another $0.9 \%$ reported it three or more times (Carpenter et al., 2002).

Delaying turning in a paper with a falsified excuse can be used not only to gain an extra week or two to complete the work, but also extended to secure a grade of Incomplete in a course. The grade of Incomplete in effect provides the extension of the deadline for submission of work, depending on college policies, often by an entire semester. As described earlier, nearly $30 \%$ of engineering students reported using a false excuse to delay either an exam or a paper at least once since starting college (Carpenter et al., 2002). 
Adding fictitious references, or references not actually used for the paper, to the bibliography or reference list is particularly important in term paper assignments where the quality and quantity of references may be a significant component of the grading rubric. Again, nearly $30 \%$ of engineering students reported such activity at least once at college (Carpenter et al., 2002). Higbee and Thomas (2002), examining more subtle variations in behaviors which might have been classified as cheating, included the related activity of citing references in a paper when only the abstract had actually been read by the student.

Copying a paper written by another student is subtly different than submitting one that has been purchased. One sorority member acknowledged receiving two term papers from a sister sorority chapter at another college, retyping them, and submitting them as her own (LaBeff et al., 1990), and one of the scenarios in Bernardi et al.'s (2004) examination of ethical reasoning applied to cheating portrayed a student using the term paper written three years earlier by her sister when she took the same course.

Cheating in assisting others. Permitting another student to look at one's answers during a test is another activity that, with some frequency, has been deemed not to be cheating, or to be readily excused due a friend's need such as an illness (LaBeff et al., 1990). This activity was reportedly allowed once or twice by $27.1 \%$ of engineering students, and three or more times by $13.7 \%$ (Carpenter et al., 2002).

Faculty at the University of Florida College of Journalism detected a student who had taken the course during a previous semester accompanying a student to an exam session, and allowing him to copy from her paper; however, the distribution of 
different versions of the exam on different colors of paper contributed to their discovery (Pactor, McNeen \& Morris, 1990).

Taking an exam for another student was acknowledged by a total of $1.8 \%$ of engineering students surveyed (Carpenter et al., 2002). Interestingly, twice as many students reported taking a test for another student three or more times $(1.2 \%)$ as reported doing so only once (.6\%) (Carpenter et al.).

Studies have included several variations on the notion of doing work for others in their organization frameworks of cheating (Angell, 2002; Carpenter et al., 2002; Graham et al., 1994; Rettinger et al., 2004; Vowell \& Chen, 2004). Providing competed homework, lab reports, or assignments for use by other students by contributing to the fraternity or sorority file of prior works have been widely recognized (Moeck, 2002; Storch \& Storch, 2002).

Little note has been given in the literature to those who provide the products for purchase when students pay for the completion of homework, lab reports, or assignments. The practice has, however, been recognized in the news media. Writing in The Wall Street Journal, Lee Gomes (2006) described Internet sites designed for the legitimate outsourcing of computer programming being used by students to get their college course assignments completed; posted comments exchanged among staff at the site complemented one student who was a repeat customer as being very good to work with.

Similarly, writing papers for pay has not been examined significantly from the supply side. The American Broadcasting Company's Primetime Live episode, "Caught Cheating," which aired April 29, 2004, included an interview of with one 
young man who described without apparent shame or remorse his lucrative endeavors writing various kinds of papers for his fellow students, including medical school application essays. When asked about his own educational and career aspirations, he replied that he planned to attend medical school (Paul, 2004). No research has been found, however, documenting the prevalence of student engagement in writing-forpay, nor the characteristics of students so engaged.

Cheating using the Internet or other technology. The technological equivalent of passing notes during a test, text-messaging during an exam to get answers allows for communication not only among students in the exam room, but also with accomplices outside the room with access to whatever references have been prepared (Cell phones, n.d.; Paul, 2004). Studies including text-messaging as a form of cheating activity have not yet been found in the literature.

Storing answers to a test in a calculator or a personal digital assistant (PDA) is the technological equivalent of the crib sheet. Information about how to download information from a personal computer into a graphing calculator, including the use of the "Notes" feature of the Texas Instruments TI-83, is readily available online (Graphing calculator, n.d.) Among engineering students, 20.4\% reported engaging in such activities once or twice since starting college, while $21.9 \%$ reported doing so three or more times (Carpenter et al., 2002).

Sending or storing cell phone photos of exam pages is the technological equivalent of removing the exam paper from the test room. This activity has also yet to be found as a cheating strategy in studies reported in the literature, but has been 
described both in the news media (Paul, 2004) and by students in online postings (Cell phones, n.d.).

Creating Internet disruptions to gain another attempt at an online exam, test or quiz is the technological equivalent of yelling "fire" to empty the room during a test so that another attempt can be had at the test, with the benefit of advance review of at least a version of the test. In the commonly-used Blackboard ${ }^{\circledR}$ online course management system, a special code appears instead of a score when a test has been attempted but not submitted as complete. The course instructor can view the attempt, including responses made to each item, items where no response was made, the date and time of the attempt, and the total amount of time the student spent on the attempt. During a time-limited test, a student who is reaching the end of the allotted time with too many items remaining may simply unplug the computer, then report to the instructor that a computer or power failure interrupted the test session and request to be granted another attempt to complete the test (E. Marshall, personal communication, October 14, 2004). Again, this activity has yet to be examined expressly in the research literature on cheating.

Accessing the instructor's or college computer system to alter grades is perhaps the ultimate example of cheating. In March 2005, a 21 year-old student at the University of California at Santa Barbara was arrested on two felony counts of illegal access into a computer system (La, 2005). She allegedly obtained faculty members' social security numbers and birthdates through her job at a local insurance company office, used that information to reset their passwords into the college record system, and then altered course grades for herself and her roommate. The fraud was detected 
when an automated notification of grade change was received by the instructors (La, 2005). While such reports have been rare, only those episodes uncovered are available for reporting.

Organizational Frameworks for the Description of Cheating

In many studies, specific activities commonly recognized or accepted as cheating have simply been listed, without attempt to create any organizational framework or develop themes of related activities (Brown, 2002; Carpenter et al., 2002; Harding, 2001; Jordan, 2001; McCabe \& Trevino, 1997; Pulvers \& Diekhoff, 1999; Roberts, Anderson \& Yanish, 1997; Robinson et al., 2004; Storch \& Storch, 2002; Sutton \& Huba, 1995; Thorpe, Pittenger \& Reed, 1997; Vowell \& Chen, 2004). While providing important information about the specific activities under study, such approaches have not placed cheating behaviors into categories that might prove useful in theory-building or the design of interventions.

The terms test and exam are generally used interchangeably or linked together; some authors specifically include or exclude quizzes in such a category, but without clarifying the distinction between a quiz and a test. The organizational framework used by McCabe and Bowers (1994) in their major 30-year comparison study focused on two categories of cheating behaviors: cheating on tests versus cheating on papers. Cheating on tests/exams included activities such as copying from another on a test or exam, helping another to cheat on a test, using crib notes to cheat on a test or exam, and copying on a test without the other student knowing. Cheating on papers or written work included activities such as copying a few sentences without footnoting, fabricating or falsifying a bibliography, turning in copied material as one's original 
work, and collaborating when individual work was required (McCabe \& Bowers). McCabe continued to use this organizational framework for cheating in his later study of business students' cheating (McCabe \& Trevino, 1995). Pincus and Schmeilkin (2003) used essentially the same organizational framework in their study of faculty perceptions of cheating: papers (copying information without using quotation marks; copying material without proper footnotes; falsifying or fabricating a bibliography) versus exams (failing to report a grading error; delaying to take an exam due to false excuse; giving exam questions to students in a later section).

Several other works have used variations on the exam versus paper framework in the study of cheating behaviors. Gaberson (1997) distinguished between cheating and plagiarism, where cheating encompassed activities related to both exams and assignments, including theft of an exam from faculty. Dickhoff and associates (1996), in their 10-year longitudinal study, differentiated quizzes from exams, and broadened the category of papers to assignments.

In his meta-analysis of 107 studies on cheating spanning from 1970 to 1996 , Whitley (1998) organized cheating into four types: cheating on examinations, cheating on homework and other assignments, plagiarism, and total cheating. Pino and Smith (2003) also used the categories of cheating on tests, cheating on assignments, and plagiarizing papers; interestingly, the activity of buying papers was included in the category of cheating on assignments, while plagiarizing papers included making up sources for bibliographic citations and copying directly or paraphrasing without citation. This study also asked students to include "other actions that would be considered academic dishonesty" in their responses (Pino \& Smith, 
Appendix, 1 1). Similar organizational frameworks were used in other studies (Rettinger et al., 2004; Thorpe et al., 1999).

Ercegovac and Richardson (2004) expanded their organizational framework to four categories of academic dishonesty: cheating (use of unauthorized materials); fabrication (falsification or invention of information or citation); facilitating academic dishonesty (helping another); and plagiarism (representing another's work as one's own). This organizational framework was credited to Burke's (1997) unpublished dissertation which examined faculty perceptions and attitudes about academic dishonesty at a two-year college. A similar framework was used by Hollinger and Lanza-Kaduce (1996): taking of information (including both exam and homework activities), tendering of information (allowing exam to be copied), plagiarism, and misrepresentation (false excuse to take an exam late); and by Storch and Storch (2002): copied other students' materials, plagiarism, exam cheating, and misrepresentation.

Recently, Dawkins (2004) organized cheating into four "dimensions of dishonesty" (p. 119): cheating on classroom tests, copying from the Internet, knowledge and awareness of others cheating, and lying to avoid detection. This scheme, as its name suggests, broadened the question to examine not only the activity most directly resulting in academic advantage, but also those activities in support of the success of cheating by self or others.

Expanded access to sophisticated technology and the Internet has opened new avenues of cheating. Although not yet found in the literature as an organizing element 
for cheating behaviors, a variety of such activities have been reported in the media as described above, and have begun to appear in the literature (Sterngold, 2004). Definitions of Cheaters

Additionally inconsistent in the literature on academic cheating has been the vast discrepancy in how researchers have classified students as cheaters. In some studies, students were classified as either cheaters or non-cheaters based on their report of having ever cheated, in any way, at any time during their college career, duration unspecified (Bolin, 2001; Brown, 2002; Bunn et al., 1992; Diekhoff et al., 1996; Rettinger et al., 2004; Smyth \& Davis, 2003; Tang \& Zuo, 1997). In other studies, students were presented with a defined time period within which to assess their behavior, sometimes the preceding academic year (Angell, 2006; Roberts et al., 1997; Robinson et al., 2004), sometimes the current semester (Jordan, 2001).

Returning to the problem of inconsistent definitions of cheating, researchers have also varied in the behaviors used to classify students as cheaters based on selfreport. In some cases, a list of specific behaviors was presented to which students responded regarding their practice (McCabe \& Bowers, 1994; McCabe \& Trevino, 1995; McCabe \& Trevino, 1997; Rettinger, Jordan, \& Peschiera, 2004; Thorpe, Pittenger \& Reed, 1999), while in other cases students were directed to limit their consideration to single sets of behaviors, such as test-cheating (Diekhoff et al., 1996; Tibbetts, 1998). In yet other cases, students were left to use their own definitions to respond regarding their history of cheating (Brown, 2002; Davis \& Ludvigson, 1995; Huss, Curnyn, Roberts, \& Davis, 1993; Pulvers \& Diekhoff, 1999; Smyth \& Davis, 
2003), or were directly observed engaging in a specific behavior (DePalma et al., 1995; Drake, 1941; Ward, 1987).

Another inconsistency has been the manner in which relative severity and/or frequency of cheating behaviors has been addressed. For some researchers, selfreported cheating in any way resulted in classification as a cheater, and cheaters of all types were grouped together in the analysis of research questions (Diekhoff et al., 1996; Jordan, 2001); for others, composite measures were developed providing a continuous variable cheating index, reflecting frequency of various types of cheating added together (McCabe \& Trevino, 1997; Pino \& Smith, 2003; Thorpe et al., 1999); and for others, both the type and the frequency of reported cheating were kept separate throughout the data analysis (Robinson et al., 2004).

The limitation of inconsistent timeframes or measurement strategies has not been restricted to self-report surveys. In the studies in which actual cheating behaviors have been observed, some students have been classified as cheaters based on several opportunities during a single college course (Gardner \& Melvin, 1988; Spiller \& Crown, 1995), while others were identified as cheaters based on a single opportunity under study (Dawkins, 1995; Ward, 1987).

Thus, it is evident that the classification of a student as a cheater has been inconsistent in the literature, making it difficult to draw wider conclusions across the literature or over time. This inconsistency only intensifies when one seeks to determine what percentage of the college student body is engaged in cheating. 
Prevalence of Cheating

Given the wide variation in how student cheating has been operationally defined and measured in the literature, there is no simple, valid response to the question of the prevalence of cheating among college students. One of the most significant limitations has been the difference in time spans over which students have been asked to report their behaviors which then resulted in their being classified as cheaters.

In a single exercise (reported successful solution of anagrams, unrelated to a course grade), $85.3 \%$ of students enrolled in undergraduate psychology classes were observed falsely reporting success (Dawkins, 1995). Another single opportunity, involving self-grading of a mid-term exam, found that $28 \%$ of all students cheated (Ward, 1987). Over the duration of a single one-semester business course, $27 \%$ of students cheated in the self-grading of quizzes (Nowell \& Laufer, 1997), while only $11.6 \%$ of those enrolled in social and behavioral science courses reported having cheated in one or more ways in the specified class (Pulvers \& Diekhoff, 1999).

Looking at behaviors in all courses during a single semester, $31.4 \%$ of students reported cheating on at least one paper or exam at a small, private, liberal arts college with an honor code in place, and an additional $28.5 \%$ cheated in some other way, for an overall prevalence of $54.9 \%$ (Jordan, 2001). Similarly, a total of $68.1 \%$ of students reported engaging, during the semester just ending, in at least one of ten cheating activities listed (Hollinger \& Lanza-Kaduce, 1996). These authors noted, however, that those students who acknowledged some type of cheating generally reported doing 
so only once or twice during the semester, as opposed to 3-5 times or 6 or more times - a finding they noted as "perhaps good news" (Hollinger \& Lanza-Kaduce, p. 302). Another variation of timeframe used has been the previous six months-a period somewhat longer than a semester, but which could have included a major period void of academic activity over the summer. Fifty-four percent of students reported cheating during this timeframe at a small southwestern university (LaBeff et al., 1990).

The prior academic year, previous year, or past 12 months has been a commonly-designated period for self reports of cheating. Using such a timeframe, $91.4 \%$ of students surveyed reported at least one cheating behavior at least once at a mid-sized public 4-year university (Roberts et al., 1997). Among students in upper division sociology classes, fewer than $10 \%$ received an illicit advance copy of an exam, $19 \%$ plagiarized a term paper, $25 \%$ falsified information on a term paper, and $33 \%$ looked at another's answers during an exam; taking a total of 17 difference cheating behaviors into account, $83 \%$ of the students surveyed reported at least one act of academic dishonesty during the prior year (Cochran, Chamlin, Wood \& Sellers, 1999). Findings were similar among students at a rural university with single-year cheating rates ranging by behavior from $33 \%$ (used exam cheat sheets) to $89 \%$ (collaborated on take-home exams) (Robinson et al., 2004), and among behavioral science students at a mid-Atlantic public university, where $39 \%$ reported copying from another student on a college exam at least once during the preceding year (Tibbets, 1998). 
Expanding the timeframe of self-reporting to the duration of college study, Diekhoff's team (1996) compared students' reports of cheating in 1984 to those in 1994. The actual time span that the duration of college study represented for their sample was not reported, although the study procedure described distribution of the surveys in core curriculum classes, so many respondents were likely in their first two years of college. The prevalence of cheating on exams remained stable over time, at $23.7 \%$ in 1984 compared to $23.1 \%$ in 1994 . Other forms of cheating, however, increased significantly. Cheating on quizzes increased from $22.1 \%$ in 1984 to $31.3 \%$ in 1994 , and cheating on assignments increased from $34.2 \%$ in 1984 to $45.1 \%$ in 1994 . These increases were of sufficient magnitude to bring the overall prevalence of cheating up significantly over time, from $54.1 \%$ in 1984 to $61.2 \%$ in 1994 (Diekhoff et al.).

Similar findings have been reported in other studies specifying the time span for report of cheating as students' college years. McCabe and Bowers (1994) found over $80 \%$ of students at non-honor code schools and over $50 \%$ of those at honor code schools, in both 1963 and 1993, admitted to at least one instance of cheating of some type while in college. More detailed analysis in this study revealed that, over time, exam cheating had increased significantly over time, driven primarily by an increase at honor code schools from $3 \%$ to $11 \%$ in helping another to cheat on a test, and an increase in unauthorized collaboration on written work at both honor code and nonhonor code schools (from $6 \%$ to $27 \%$ at honor code schools; $18 \%$ to $45 \%$ at nonhonor code schools), but that other forms of cheating, especially on written work, had actually decreased over time (McCabe \& Bowers). McCabe and Trevino (1995) 
reported that $67 \%$ of students acknowledged one or more instances of cheating while in college, with $38 \%$ reporting three or more such instances of any type of cheating, and $15 \%$ reporting three or more instances of cheating on exams. Davis and Ludvigson (1995) gathered self-report data from 71 classes in 11 different states, and reported that the cheating rates of their samples ranged from $42 \%$ to $64 \%$; they did not report an aggregate rate. At a highly selective four-year liberal arts college, $88 \%$ of students reported some type of cheating activity while in college; $53 \%$ reported cheating on exams, $42 \%$ on papers, and $70 \%$ on homework or laboratory assignments (Rettinger et al., 2004). Rather similar finding were reported from a southwestern university, with $85 \%$ reporting at least one episode of cheating while in college, $35 \%$ copying on a test and $74 \%$ copying homework (Vowell \& Chen, 2004), and at three Midwestern state universities, where $39 \%$ of students admitted to exam cheating (Tang \& Zuo, 1997). Finally, overall cheating prevalence of $80 \%$ was calculated from reports of $66 \%$ at a small college and $92 \%$ at a large college, ranging from $11 \%$ of students submitting another's paper as their own to $36.7 \%$ copying another's homework (Thorpe et al., 1999).

A number of studies have categorized students as cheaters based on their report of having ever cheated, in any way, during their academic careers. Therefore, a limitation, in considering these reports in terms of college cheating is the uncertainty as to whether reported cheating actually occurred during college coursework. Among students in microeconomics courses, $50 \%$ reported having cheated, ever, on a test or written exam (Bunn et al., 1992). In her survey of nursing students, Brown (2002) found self reports of cheating (Have you cheated?, timeframe unspecified) ranging 
from $8 \%$ among sophomores and juniors to $20 \%$ among seniors and $39 \%$ among freshman; associate degree nursing students reported cheating at 13\%. Among engineering students, respondents reported having engaged in behaviors that a majority considered to be cheating (no timeframe specified) ranging from $0.6 \%$ on taking an exam for another student to $27.7 \%$ on copying an old term paper or labreport from a previous year and working in groups on take-home exams (Carpenter et al., 2002). Overall, $93 \%$ of these engineering students reported having engaged in at least one activity that a majority rated as either cheating or unethical (Carpenter et al.).

Other researchers have left the timeframe for students to consider in reporting their cheating unspecified. Dawkins (2004) used this approach, and reported students' cheating overall at $41.4 \%$, which he compared to Whitley's (1998) review as falling at midpoint between earlier reports of $4 \%$ to $82 \%$. Dawkins also reported cheating on each of his four individual dimensions of dishonesty: $41 \%$ cheated on exams, but the largest portion of exam cheaters $(21 \%)$ reported such behavior only rarely (as opposed to some or a lot); $18.8 \%$ reported cheating on the Internet; $70.4 \%$ reported knowledge of others' cheating; and $29.5 \%$ reported lying to avoid detection.

In order to examine changes in cheating over time, McCabe and Bowers (1994) purposefully sampled to allow comparisons with a study done 30 years earlier. They found that exam cheating had not increased dramatically, and that there had actually been a decline in the levels of many other forms of cheating. However, unpermitted collaboration on written assignments had increased three-fold (McCabe \& Bowers). Similarly, a comparison of cheating in 1984 with that in 1994 found that the overall rate of cheating increased significantly, from $54.1 \%$ to $61.2 \%$, but that this 
change was driven by increases in cheating on assignments and quizzes while cheating on exams remained unchanged (Diekhoff et al., 1996). In the 2003 National Survey of Student Engagement, $87 \%$ of respondents reported that their peers had copied data from the Internet without citing sources (Sterngold, 2004).

Several studies have examined the prevalence of cheating in very specific situations. Testing of the widely-held presumption that cheating would be greater in online classes than in traditional settings failed to substantiate the belief, with a reported cheating rate of only $3 \%$ compared to published rates of $1.9 \%$ to $13 \%$ in single traditional classes (Grijalva, Nowell \& Kerkvliet, 2006). In some of the few studies to actually observe and measure cheating behaviors, Dawkins (1994) found that $85.3 \%$ of participants cheated during a one-time exercise which did not have any impact on participants' future course grades, while Ward (1987) found $28 \%$ and Drake (1941) found $24 \%$ of students cheating by changing answers on an exam that they believed would impact their course grades

In his 1998 meta-analysis of 107 studies, Whitley failed to address the difference in how researchers had determined the prevalence of cheating. He did, however, recognize the different types of cheating being studied. Thus, he reported the prevalence of cheating on exams ranging from $4 \%$ to $82 \%$ of students, with a mean of $43 \%$; cheating on homework ranging from $3 \%$ to $83 \%$, with a mean of $41 \%$; and plagiarism ranging from $3 \%$ to $98 \%$ with a mean of $47 \%$. Total cheating (not broken down into categories or aggregated from type-specific reports) ranged from $9 \%$ to $95 \%$, with a mean of $70 \%$ (Whitley). 
One purpose of Whitley's (1998) analysis was to focus on studies published since 1970, in recognition that older research might have limited application to the college students of the late $1990 \mathrm{~s}$. He found a curvilinear relationship between mean cheating prevalence rates by year of study, shown below:

- $1969-1975 \quad 44.9 \%$

- $1976-1980 \quad 24.8 \%$

- $1981-1985 \quad 32.2 \%$

- $1986-1990 \quad 46.4 \%$

- $1991-1995 \quad 46.9 \%$ (Whitley).

Another strategy to assess whether cheating had truly changed over time was used by Spiller and Crown (1995). Their meta-analysis used 24 studies where cheating was directly observed in students' changing of answers on self-graded quizzes, and did not support the frequent lament among faculty that cheating was on the rise (Spiller $\&$ Crown).

From these reports, it is clear that there have been various practices by students within the universe of academic cheating behaviors. The fact that patterns of behavior have changed over time may be related to generational differences, and the greater age-span of students served in community colleges compared to most 4-year institutions (AACC, n.d.) makes this issue more relevant in the community college setting. In the only study identified in a two-year college setting, $45.6 \%$ of students reported having cheated at least once while in college (Smyth \& Davis, 2003). 


\section{Characteristics of Students Who Cheat}

The vast majority of the research on college student cheating has sought to establish correlations between various student characteristics and cheating. Two major reviews have summarized the literature from 1970 to 1996 (Crown and Spiller, 1998; Whitley, 1998).

Age. Diekhoff and associates (1996) found that cheaters were significantly younger than non-cheaters in both their 1984 and 1994 samples, and this finding has been supported by others (Dawkins, 2004; Harding et al., 2002; Jordan, 2001; McCabe \& Trevino, 1997; Roberts et al., 1997; Vowell \& Chen, 2004). Whitley's (1998) review found that cheaters tended to be younger, with age having a moderate effect size.

Crown and Spiller (1998), however, found age to have mixed results as a correlate to cheating, and noted that the age span in most studies had been restricted to five years. Harding et. al. (2002) noted that the only strong correlation between age and any other characteristic as related to cheating was that between age and the school lacking an honor code. Their explanation for this finding was that their sample included 12 percent community college students, lacking honor codes, and enrolling students of significantly higher ages than the traditional four-year institutions with honor codes (Harding et al.). Other recent studies have found no significant relationships between age and cheating (Jordan, 2001; Robinson et al., 2004), and even the reverse of prior findings -- that older students were more likely to cheat than younger students (Pino \& Smith, 2003). In Pino and Smith's study, the correlation of lower age with less cheating diminished when the variable of academic ethic 
(expressed valuing of academics over social life, daily studying, consistent class attendance, etc.) was controlled.

In some studies, the variable of age has not been studied per se, but could be generally inferred form another variable. Rettinger et al. (2004) reported no significant differences in cheating behavior among academic classes (e.g., freshman, sophomores, juniors and seniors) in a sample ranging in age from 18 to 22 years; age and academic class were likely highly correlated in such a group.

Moral development and college experience. A number of researchers have tested hypotheses about cheating derived from theories of moral development, postulating that higher levels of moral development should result in less cheating. Bernardi's team (2004) studied primarily business and psychology students, and found that situational factors (e.g., deadlines, consequences of failure, risks of detection, etc.) impacted cheating behaviors more so than level of moral development, and that business majors scored lower than students in other disciplines. Whitley's metaanalysis (1998) found cheaters to have lower levels of moral development - but with a small effect size - in a total of seven studies exploring this relationship. Crown and Spiller (1998) reported four such studies, three of which documented significant relationships between measures of moral obligation or moral code and lesser rates of cheating.

Whitley's (1998) review also identified that students who felt little moral obligation not to cheat were more likely to cheat than those who did feel such moral restrictions (medium effect size). Although later researchers failed to substantiate this relationship in a naturally occurring cheating situation, they cited the limitation of 
their small sample (West, Ravenscroft, \& Shrader, 2004). Tibbetts (1998) found that students' intent to cheat (limited to cheating on tests) was significantly related to their moral beliefs about test cheating, but he did not assess their levels of moral development.

The Defining Issues Test (DIT) has been widely recognized as a measure of moral development (Rest, Thoma, \& Edwards, 1997). Used as part of a design to relate overall moral development with specific attitudes towards academic dishonesty, the DIT showed that attitudes towards cheating were more powerful in predicting cheating behaviors than were demographic variables such as gender or major course of study (Bernardi et al., 2004).

Given the relationship described above between age and cheating, where younger students have been generally found more prone to cheating than older students, one could question whether the relationship between moral development and cheating simply reflects longer life experience. King and Mayhew (2002) reviewed 172 studies that used the DIT among undergraduate college students; they concluded that participation in higher education contributed significantly to development in moral judgment beyond that attributable to age alone. James Rest, a major contributor to the research in moral development, explained the impact of age and higher education on moral development as follows:

The general trend is that as long as subjects continue in formal education, their DIT scores tend to gain; when subjects stop their formal education, then their DIT scores plateau. Consequently, if you wanted to predict the DIT scores of adults, you would do best by knowing their education level, 
not age or gender. (Rest, 1994, p. 15)

Diekhoff's group (1996) utilized a series of 11 items to determine a Total Neutralization Score, which was described as strategies to "sidestep the rules and deflect blame or guilt" (p. 491). In both their 1984 and 1994 samples, cheaters scored significantly stronger on neutralization than non-cheaters. Interestingly, both groups decreased in neutralization over time, with cheaters engaging in significantly less neutralization in 1994 than in 1984.

Research on these variables in the community college setting has been sparse. A single such study found that, among community college students, fewer cheaters $(88 \%)$ than non-cheaters $(96 \%)$ believed that cheating was ethically wrong (Smyth \& Davis, 2003).

Gender. Men have historically been shown to cheat more often than women (Roberts, 1997), and in some recent studies, this finding persists (Dawkins, 2004; Rettinger et al., 2004; Vowell \& Chen, 2004). In Whitley's (1998) meta-analysis, males were shown, by self-reports only, to cheat more often than females, but the effect size was small $(d=.22)$, and the gender differences in observed cheating were not significant. Whitley suggested that men may be more willing than women to admit to cheating, perhaps feeling less guilt.

In a later review of 48 studies focused specifically on gender differences in cheating, a distinction was made between attitudes towards cheating and actual cheating behaviors. Men reported both having more positive attitudes towards cheating, and having actually cheated more than women. However, the mean effect size for gender differences in attitudes towards cheating was determined to be 
moderate, while the mean effect size for gender differences in cheating behavior was found to be small. In their conclusion, the authors warned about the issue of statistical power generating statistically significant results in large samples when only small effect sizes are involved (Whitley, Nelson, \& Jones, 1999).

While some recent studies have continued to find men cheating more than women (Dawkins, 2004; Rettinger et al., 2004; Vowell \& Chen, 2004), the relationship of gender to cheating has changed over time. Crown and Spiller's (1998) meta-analysis found that studies done prior to 1972 reported males cheating more than females, but that this relationship became less stable over the next 20 years, with a prevalence of non-significant relationships in the last 10 years. Gender has either not been significant, or had a correlation with cheating deemed by the researcher too weak to report, in a number of recent studies (Carpenter et. al., 2002; Harding, Carpenter, Montgomery \& Steneck, 2002; Jordan, 2001; Kerkvliet \& Sigmund, 1999). In other studies, the effect of gender was no longer significant when variables such as academic ethic were controlled (Pino \& Smith, 2003), or when examined in regression analysis with more complex factors such as enjoyment of college and fear of punishment (Robinson et al., 2004). In still other studies, women have been more likely to cheat than men (DePalma et al., 1995; Graham et al., 1994).

Examined more closely, gender was shown to have an interesting interaction relationship with individuals' ability to persist as related to cheating: women who scored higher in persistence cheated less than women who scored lower in persistence, while the cheating of men was unrelated to persistence (DePalma et al., 1995). 
Program of study. Several researchers have examined differences among students in different major disciplines of study in their attitudes towards and engagement in cheating. For example, business majors reported significantly more cheating than engineering/science, humanities/social science, and other majors (McCabe \& Trevino, 1995). In their analysis of open-ended questions, McCabe and Trevino found that the primary motivation for cheating was the pressure to get good grades, often in terms of the competition for admission into the most prestigious master of business administration programs. This was coupled with students' perceptions that their classmates were getting ahead by cheating, and that they therefore needed to cheat simply to hold their relative rank in class. Business majors were also found to report cheating more often than students in any other major at the community college level (Smyth \& Davis, 2003).

One of the most recent public cheating scandals, 33 first-year M.B.A. students at Duke University's Fuqua School of Business were found to have inappropriately collaborated on an open-book take-home exam in a required course (Young, 2007). Commenting on the situation, James R. Bailey, professor of leadership at the George Washington University School of Business, noted that that business schools may, by the very nature of the material they teach, breed a certain amount of academic dishonesty, with a culture of competition and self-interest. "In our theory classes, we're teaching theories of advancing one's self-interest. All the formal mechanisms in the world - honor codes, having everybody read it during classes, an ethics class can't overcome culture" (Young, \13). Bailey went on to observe that students who collaborated may have been building useful skills. "They were enterprising, they took 
initiative, and they worked together. Aren't those all the qualities we're trying to encourage of business school students?" (Young, ๆ 15).

Refining the examination of cheating among students in different academic disciplines, Roberts' group (1997) found that the greatest prevalence of unauthorized collaboration was among business majors, while the greatest prevalence of giving false excuses to delay turning in papers or taking exams was among performing and visual arts majors.

Personal morality and religious involvement. Crown and Spiller's (1998) analysis reported two studies that examined religion as a correlate of cheating, neither of which proved significant, leading the meta-analysis authors to conclude that researchers interested in cheating should pay greater attention to students' ethical decision making than to their religious involvement. However, although their meta analysis did include the work of Graham, Monday, O'Brien and Steffen (1994), which examined attitudes and behaviors in academic cheating among students at a Catholic college and a community college, the group's work was not included in Crown and Spiller's specific analysis of religion. Although religion was not among the principle variables which emerged in the regression analysis completed by Graham's group lenient attitudes towards cheating, belief that cheating is not that severe an offense, and belief that a large number of other students at the school are cheating - students who had lenient attitudes towards cheating reported being less religious than those had stricter attitudes; the exact phrasing of their survey question(s) related to religion was not reported (Graham et al.). 
Tibbits (1998) found non-criminal justice majors more strongly influenced about cheating by their moral beliefs than criminal justice majors, but the connection, if any, to a religious belief system was not explored. Sutton and Hubs (1995) included level of religious involvement among the student characteristics they correlated with perceptions of academic dishonesty, and found that students with the highest levels of religious involvement were more likely than those in the lowest group to agree that "cheating is never justified under any circumstances." However, Vowell and Chen (2004), in comparing the predictive value for academic cheating of four alternate theoretical models, found that the model including religious activities did not prove the most powerful. Altogether, there has been little reported in the literature about the relationship of students' connection to a religious belief system and their attitudes or behaviors in academic cheating.

Other characteristics. Whitley's (1998) meta-analysis identified that the student characteristics most strongly correlated with cheating, with large effect sizes and in more than five studies, were holding favorable attitudes towards cheating, and perceiving that social norms allowed cheating; in fewer than five studies, large effect sizes were also noted for moderate expectations of success (as compared to high or low expectations), having cheated in the past, studying under poor conditions, and anticipating a large reward for success in cheating. Whitely found that the often studied characteristics of belonging to Greek organizations, having a higher need for approval, and having an internal locus of control had only small effect sizes.

Students with lower levels of academic achievement may be more prone to cheat than those who have lower grades. Grade point average (GPA) has been 
established to have a significant negative relationship with cheating in a number of studies (Bunn et al., 1992; Crown \& Spiller, 1998; Diekhoff et al., 1996; Kervliet \& Sigmund, 1999; McCabe \& Trevino, 1997).

Whitley's (1998) meta-analysis also found this relationship, but noted it as a small effect size. GPA did not distinguish cheaters from non-cheaters at an honor code college (Jordan, 2001) or a rural college (Robinson et al., 2004) but did have a significant relationship both to past cheating and likelihood of future cheating among marketing and management majors (Smith, Davy \& Easterling, 2004).

Among recent engineering students, GPA was found to negligibly correlate with cheating $(< \pm 0.2)$ (Carpenter et al., 2002). Similarly, GPA was not a significant factor related to cheating at a mid-sized public university (Roberts et al., 1997). The correlation between GPA and cheating that was found by Pino and Smith (2003) was no longer significant when the variable of academic ethic (expressed valuing of academics over social life, daily studying, consistent class attendance, etc.) was controlled. Among business students, GPA did not correlate significantly with cheating, but grade achieved in the specific course under study did (Nowell \& Laufer, 1997).

In their study in the community college setting, Smyth and Davis (2003) found no differences in the rates of cheating reported between those who were full-time versus part-time students, or between those who lived in dorms versus those who lived off-campus. 
Settings and Circumstances of Student Cheating

What Whitley termed perceiving that social norms support cheating proved to be one of the most significant factors that emerged from his meta-analysis (1998). Reported in 16 studies, students who perceived that social norms supported cheating engaged in more cheating than students who perceived non-supportive norms at an effect size of .929 , considered large. Recognizing that one of the most recent studies included in this analysis used a very large sample and thus could have disproportionately impacted his analysis, Whitley removed this study from the analysis and found an effect size of .564, considered moderate. He argued, however, that this more recent national study may have been a more accurate estimate of the true population effect size, lending support to the larger effect size estimate in his original analysis.

Further support of the impact of social norms has come from other studies. McCabe and Trevino (1997) concluded that the most important factors related to student cheating were peer-related contextual factors, specifically peer disapproval and peer behavior, and members of fraternities and sororities reported higher rates of cheating than nonmembers (Storch \& Storch, 2002). Similarly, students in microeconomics classes were more likely to cheat when they observed others cheating, and when they believed that higher percentages of their fellow students were cheating (Bunn et. al., 1992). Perceived peer cheating remained significant in a multivariate regression analysis of rural college students (Robinson et. al., 2004), and friends' cheating behavior was significantly more powerful than moral beliefs or perceived pleasure of cheating in predicting intention to cheat among criminal justice 
majors than among students in other disciplines (Tibbets, 1998). Among engineering students in a multi-campus study, the most powerful predictor of student cheating was the student's sense that cheating was necessary to succeed (Harding, Carpenter, Montgomery, \& Steneck, 2002), while knowledge of others cheating proved a powerful covariate in Dawkins' (2004) study. Vowell and Chen (2004) found similar relationships between cheating and the number of respondents' friends who cheated and favorable attitudes towards cheating.

Focused on the relationships between cheating and various classroom environmental factors, Pulvers and Diekhoff (1999) found that students who reported cheating also reported that their classes were less personalized, less task-oriented, and less satisfying than did non-cheaters. Cheating on exams at a smaller college (8.8\%) was significantly lower than exam cheating at a larger college (19.3\%) (Thorpe et al., 1999).

Other significantly contextual factors related to cheating have been the status of the instructor and characteristics of the class. Business students were more likely to cheat in classes taught by graduate teaching assistants (Kerkvliet \& Sigmund, 1999) or adjunct faculty as opposed to classes taught by full-time faculty, and in larger rather than smaller classes (Nowell \& Laufer, 1997),

In meta-analyses, students have been shown more likely to cheat at institutions without honor codes, when they carried higher academic workloads, when they sat next to another cheater or next to friends, and when only one version of a test was given; each of these characteristics has been demonstrated at a medium effect size (Crown \& Spiller, 1998; Whitley, 1998). Cheating rates and student characteristics 
associated with cheating at a rural university were similar to those reported from urban institutions (Robinson et al., 2004).

Research has consistently documented students' reports of cheating more often in unmonitored, out-of-class situations than during proctored examinations.

Plagiarism and copying of homework were reported more often than cheating on tests or submitting another student's paper (Thorpe et al., 1999), and copying from the Internet was more common than cheating on tests (Dawkins, 2004).

Methods of Study

Several approaches have been taken in the study of student cheating, most commonly self-reports and surveys, less often direct observations, and least often qualitative investigations. Examples of each of these approaches will be described below, including discussion of their strengths and limitations.

Self-reports and surveys. Direct question surveys (DQS) have been the most widely used methodology in the study of student cheating (Angell, 2006; Bolin, 2004; Cochran et al., 1999; Dawkins, 2004; Diekhoff et al., 1996; McCabe \& Bowers, 1994; McCabe \& Trevino, 1995, 1997; Pino \& Smith, 2003; Robinson, et al., 2004). While simple and inexpensive, the DQS method does not account for problems inherent in asking subjects threatening questions (Kerkvliet \& Sigmund, 1999), which may be a concern when subjects are asked to report their actual cheating behaviors. Additionally, although some authors have cited the framework or model of earlier works in the development of their surveys, (e.g., Bolin [2004] based on McCabe and Trevino [1997]), no commonly accepted DQS has emerged for the assessment of cheating activities. 
Several studies have combined DQS of cheating behaviors with a rating or evaluation of behaviors as to their severity of cheating. Angell (2006) constructed the Academic Integrity Scale, on which students were asked to respond to 18 items as to the frequency of their involvement during the past year (Never/Once or Twice/Several Times) and their evaluation as wrong (Not Wrong/Somewhat Wrong/ Extremely Wrong). In her analysis, she found that two factors emerged and most common and most strongly evaluated as wrong: Test Assistance (four items, accounting for $27 \%$ of total variance) and Plagiarism (two items, accounting for $14 \%$ of variance).

One approach to overcoming the limitations of the DQS has been the randomized response survey (RRS), which was argued by Kerkvliet and Sigmund (1999) to foster truthful responses by providing subjects with greater anonymity by allowing a sensitive question to be answered without revealing with certainty their true status regarding the sensitive behavior. These authors cited three previous works comparing DQS with RRS results in the study of cheating, two of which found DQS to underestimate cheating while one found the opposite. This technique was recently used to assess cheating during an online course, where the researchers were particularly concerned about students' distrust in confidentiality as a limitation of their study (Grijalva, et al., 2006). The RRS technique intertwined questions about birthmonth with questions about cheating in the online course in such a way that, having calculated the probability of being born in identified months, the researchers could determine that positive responses in excess of the probability of being born in the identified months would reflect the proportion of cheating being acknowledged (Grijalva, et al., 2006). 
Another variation of the survey approaches was used to describe relationships among different psychosocial variables and students' predictions of cheating behavior in others. Rettinger and associates (2004) constructed four vignettes describing situations of male college students in a general studies course, manipulating the protagonist's academic motivation and perceived ability, and then asked students to predict the likelihood that the protagonist would cheat in the situation described. Prediction results were then correlated with various student characteristics. Students rated protagonists more likely to cheat when they were portrayed with high levels of extrinsic goal motivation related to the course material as compared to protagonists portrayed with high levels of intrinsic motivation. Students who rated their own personal likelihood of cheating high also rated protagonists more likely to cheat, compared with students with low likelihoods of cheating, and also scored higher in personal extrinsic motivation and actual cheating (Rettinger et al.).

The risk for inconsistent operational definitions of cheating has been a limitation in any self-report or survey study where specific behaviors, or specific time periods for self-report, were not described. These inconsistencies have been described above in relation to the definitions of cheaters and the prevalence of cheating.

Direct observations. Direct observation of cheating has also been reported as a study methodology. Spiller and Crown (1995) conducted a review of studies from 1927 to 1986 , all of which used students' changing of answers on self-graded tests as a measure of cheating. In these studies, test answer sheets were collected at the end of the exam period. At the next class meeting, answer sheets were returned to students for self-grading, often with a pretext from the instructor of not having had time to 
grade the tests. Students' self-graded answer sheets were then collected in order for grades to be recorded. The self-graded answer sheets were compared with copies of the answer sheets as originally submitted, allowing for a behavioral measure of cheating.

Researchers have continued to use this methodology, but not widely (Nowell \& Laufer, 1997; Ward, 1987). Critics to this approach have argued that, although it had the advantage of not relying on students' truthful self-report, it placed students in a contrived situation that reflected only one of many possible cheating opportunities, and may have had the appearance of entrapment (Kerkvliet \& Sigmund, 1999).

Another approach to the direct observation of cheating was used by Gardner and Melvin (1988). Teaching introductory college psychology, the researchers supplied workbooks with answer pages to accompany the course textbook. Students were instructed to complete the workbook pages in ink using their textbooks for reference, and that they were permitted to check their responses against the answer pages but were not to make any changes to their workbook pages. Keyed responses in the answer pages were deliberately phrased differently from the textbook, insignificant to the concepts, but using synonyms or re-sequencing words. Cheating was measured as a percentage of answers apparently taken from the answer key divided by the total number of questions completed (Garner \& Melvin).

Qualitative investigations. A few qualitative studies have been reported, focusing on the motivations, justifications, and thought processes of those who admitted to academic cheating (Johnston, 1996; McCabe, Trevino \& Butterfield, 1999; Wright, 2004). In qualitative analysis of open-ended survey question responses, 
McCabe and associates focused on the differences between students at honor code versus non-honor code institution in their thoughts about academic integrity. They found commonalities in that much cheating was motivated by pressures to succeed but differences in their likelihood to justify cheating based on these pressures (McCabe et al.).

Johnston (1996) conducted interviews of students who had been involved in exam cheating in her own seminar, Moral Development and Education, during the previous semester. She identified two moral orientations through which to explore students' discussion of cheating, justice and care, and she concluded that these students had been taught to value individual achievement and responsibility, but not collective responsibility. "What these students [had] learned in school [was] to do their own work and look out for themselves" (Johnston, 1996, p. 168). The college students that Johnston studied in 1996 were likely members of Generation X (a senior level seminar class, most students probably born between 1972-1975), and this conclusion will ring true as generational differences in attitudes and values are described below.

DelCarlo and Bodner's (2004) qualitative analysis of students' work in chemistry classroom laboratories found that their Millennial generation students clearly differentiated between copying from others and sharing data - copying was dishonest, while sharing was an acceptable strategy for the completion of the required task. This finding, too, will seem consistent with the later descriptions of generational attitudes and values. 
Instrumentation

As described earlier in relation to the definitions of cheaters and the organizational frameworks used in the study of cheating, the activities included in surveys of students' cheating have varied widely. Harding et al. (2002) noted that many studies have used students' reports of specific behaviors to classify them as cheaters, therefore not capturing forms of cheating which were not included in the activities listed. Equally problematic, however, have been approaches such as Jordan's (2001), where students have simply been asked to report cheating, without any example or definition of what was to be considered cheating. One of the most comprehensive surveys of cheating activities was developed by Carpenter's team (2002), which included 20 activities ranging from copying from another student during a test or quiz to studying with other students for a test.

Some studies have described behaviors with even greater precision, such as Angell's (2006) Academic Integrity Scale that included 18 items, 7 of which were subtle variations of plagiarism (e.g., copying a paragraph versus copying a sentence). In some cases, this level of precision in description of behaviors may risk underestimation of cheating prevalence. For example, Cochran et al. (1999) specified actions of receiving an illicit, advance copy of an exam and looking at another's answers during an exam, potentially leaving students who engaged in other forms of exam cheating unrecognized as cheaters.

At the other extreme, some researchers have left the determination of what activities constitute cheating to the respondent, inquiring only as to students' cheating on a test or a written assignment, without specifying what type of cheating occurred 
(Bunn et al., 1992; Dawkins, 2004). Again, this approach may have risked underestimation of the occurrence of activities which the researcher would have considered cheating, but students did not.

A few studies have included students' perceptions, classifications, or evaluations of activities as cheating, and/or a rating of the severity of cheating for each activity, as part of the study design (Graham et al., 1994; Higbee \& Thomas, 2002). However, as long as students have been asked to report their personal engagement in potentially shameful activities, the limitations of subject bias and social desirability have remained a significant concern. Recognizing the potential impact of the risk of self-disclosure on respondents' candor, Gardner and Melvin (1988) developed their Attitude Toward Cheating scale purposefully without inquiry into personal behaviors. Rather, they focused on attitudes toward cheaters (e.g., "unethical people"), toward the morality of cheating ("morally wrong"), and toward instructors' actions ("in effect okaying cheating") (Gardner \& Melvin, p. 429).

As described above, the prevalence and types of cheating may have been shifting over time. One approach to analyzing such changes is to consider the prevailing attitudes and beliefs of the society within which studies have been done. In the next section, the characteristics of current generations of U.S. college students will be discussed, particularly as they may provide insight into the attitudes and behaviors of these students related to academic cheating.

\section{Generational Analysis}

William Strauss and Neil Howe have written extensively on the cyclical dynamic of generational behavior and the different manner in which each generation 
in the U.S. has experienced the life cycle. Reviewing history from the perspective of how social moments (decades during which people perceive that events are radically altering their social environment), these authors have offered explanations for shifts in prevailing attitudes, values, and behaviors from one generation to the next (Howe \& Strauss, 2000, 2003; Strauss \& Howe 1991, 1997). They have also posited that "each generational type specializes in its own unique brand of positive and negative endowments [italics removed from original]" (Strauss \& Howe, 1991, p. 39).

Students at U.S. community colleges today represent three primary generations, and the generational perspective has proven meaningful to writers working with individuals in a variety of settings, from language arts (Godwin-Jones, 2005), to law school (Kasting, 2006), to libraries (Holliday \& Li, 2004), to workplace training (Allerton, 2001). Those under age 25 in today's colleges and work settings have been variously named Millennials, Echo Boomers, Generation Y, Gen Net, or Gen Next (Alch, 2000; Allerton; Howe \& Strauss, 2000). Although minor variations were found among writers in the birth-year designations and names for these generations, those defined by Howe and Strauss (2000) will be used in this study: Boomers, born 1943-1960; Generation X (Gen X), born 1961-1981, and Millennials, born 1982-2000.

Boom generation. "As Boomers have charted their life's voyage, they have metamorphosed from Beaver Cleaver to hippie to braneater to yuppie to what some are calling 'Neo-Puritan”" (Strauss \& Howe, 1991, p. 299). As children, Boomers were highly nurtured, with only $2 \%$ attending institutional child care. They were the first to benefit from the development of immunizations against common childhood 
diseases such as diphtheria and polio, and were raised by G.I. and Silent generation parents to be idealistic, to look inward for the solutions to life's problems. Through their coming of age in the 1960 s to 1970 s and rising adulthood, Strauss and Howe (1991) described the Boomers' sense of mission as one of "purifying" society (p. 301). Boomers have been characterized as regarding their jobs as "anchors in their often turbulent lives"' (Smith, 2006, p. 11). They value work that provides personal satisfaction, and as they approach retirement, are looking for ways to give back to others (Smith). This motivation has brought some of them to return to school, in community college classes, after retirement from their first careers (Kelch, 2006).

Now ranging from 46 to 63 years of age, Boomers represent $10.8 \%$ of students enrolled on Virginia community college campuses in the fall semester of 2005 (VCCS, 2006a), and include some of the top-ranking graduates (Fosdick, 2005). The group has developed a schism between modernist ("New Agers") at its older end and traditionalists and evangelicals at its younger end, but has continued to provide the "leading visionaries and 'wise men' - or just its preachy didactics - regardless of the age bracket they occupy" (Strauss \& Howe, 1991, p. 316). Taken together, these characteristics may make Boomers, compared to younger students, more likely to regard certain academic behaviors as cheating, especially in the areas of group work and assisting others.

Generation X. "Speaking as Generation Xers, all we want out of life is a good job, a nice car, and a nice house. We want to enjoy life instead of scurrying around like laboratory rats. If that makes us slackers, then so be it. We would rather be slackers than spend our lives with our heads in the sand or up in the clouds" (Brown, 
Haviland, \& Morris, 1997, p. 2). As children, Generation Xers felt the highest parental divorce rate in U.S. history, with twice the risk of parental divorce than that of Boomer children, and less likelihood of receiving child support from a noncustodial parent. Their families were also more complex, with more step-parents and half-siblings. College completion rates seven years after high school fell to $37 \%$ for the first Generation X Class of 1980, down from 58\% for the Boomer Class of 1972. Cynicism, fear, suicide, and incarceration all reached levels in this group surpassing several prior generations (Howe \& Strauss, 1991). Slang terms such as emotional ketchup burst (" $[\mathrm{t}]$ he bottling up of opinions and emotions inside oneself so that they explosively burst forth all at once, shocking and confusing employers and friendsmost of whom thought things were fine"[Coupland, 1991, p. 21]) and overboarding ("[o]vercompensating for fears about the future by plunging headlong into a job or life-style seemingly unrelated to one's previous life interests'[Coupland, p. 26]) epitomized Generation X.

In their study of business students' college cheating, McCabe and Trevino (1995) cited one active cheater who rated being very well off financially as his most important life goal, and who cited his personal philosophy as a major determinant of his behavior: "It's the 90s, you snooze, you lose" (p. 211). Studying the relationship of alienation to cheating among 13 to 18 year-olds in 1990 , Calabrese and Cochran (1990) were examining Generation Xers when they concluded with concern, that as future leaders, these individuals would place greater priority on economic achievement than on contributions to society. Generation Xers have been characterized as individualistic and assertive, taking personal responsibility for the development of the 
skills needed for employability, and they are seen as likely to continue to seek new career options throughout their lives (Smith, 2006).

Now ranging from 25 to 45 years of age, Generation Xers represented $36.1 \%$ of students enrolled on Virginia community college campuses in the fall semester of 2005 (VCCS, 2006a). Generation Xers, compared to Boomers, were shown to hold more negative affect towards jobs, parents, and yuppies (slang term for young urban professionals) (Manolis, Levin, \& Dahlstrom, 1997), and have generally developed a reputation for being streetwise, savvy, and anti-institutional; having developed "a seasoned talent for getting the most out of a bad hand....they know how to win" (Howe \& Strauss, 1991, p. 334). As described above, working with Gen Xers in her qualitative study on cheating, Johnston (1996) concluded that these students had been taught about individual achievement and responsibility, but not about collective responsibility.

Millennial generation. "Millennial attitudes and behaviors represent a sharp break from Generation $\mathrm{X}$, and are running exactly counter to trends launched by the Boomers (Strauss \& Howe, 2000, p. 7). As children, Millennials were raised in the lowest parent-to-child ratio in U.S. history, during years focused on quality education, child safety, and team achievement (Howe \& Strauss, 1991).

Millennials have been characterized as adaptable and flexible, with free agent mentalities tempered with realistic expectations (Smith, 2006). As the Internet generation, they are dependent on technology perhaps at the expense of basic skills in reading, writing, and math (Smith). Marrying earlier than Generation Xers and Boomers, Millennials are returning to traditional values in many ways (Slapinski, 
1999). Other major differences of this generation from the two preceding it have been described as

- Sharing the load-having held part-time jobs in high school and college Millennials have not been as overindulged as Gen Xers

- Global orientation. - having grown up understanding the need for interconnectivity to the worldwide community

- Not the Cleavers - as the concept of how a family is defined has changed, Millennials view a wide variety of family configurations as normal

- Reality bound - having witnessed little company loyalty or job security among their elders, Millennials understand that their training, skills, and abilities are essential for securing employment and establishing a career pathway

- Cool with chaos - having come to regard constant and turbulent change as normal, Millennials are more attuned to the need to make adjustments in midstream and have contingency plans (Alch, 2000, p. 1-2).

Now ranging from 6 to 24 years of age, Millennials represented $53.1 \%$ of Virginia community college students on campus during the fall of 2005 (VCCS, 2006a). This group has been raised to believe that they are highly valued, and they have been significantly sheltered. They are largely confident, highly team-oriented, and strikingly conventional; they have also been significantly pressured, and have generally achieved success (Strauss \& Howe, 2000). Documenting the approaches of Millennials to research assignments, Holliday and $\mathrm{Li}(2004)$ noted that these students interacted differently, such as saving entire articles to a computer rather than reading 
them thoroughly at the first encounter (not taking notes), and concluded that they were operating in a new kind of information world with different expectations and behaviors than earlier students.

The generational shift. The underlying shift in attitudes, values, and behaviors among these generations has not been accidental; it has in large measure been created by the education designed and delivered by earlier generations. As described by Strauss and Howe (2000):

- In the $1950 \mathrm{~s}$ and " $60 \mathrm{~s}$, schools prepared Boomers to be inner-driven, ideal-cultivating individualists.

- In the in the 1970 s and ' 80 s, schools prepared Gen Xers to be street-smart free-agent entrepreneurs.

- In the 1990 s, schools prepared Millennials to be outerdriven, ideal-following team players. (p. 166)

The impact of these changing attitudes, values, and behaviors has been documented and discussed in relation to both higher education and the workplace. Writing for those in the human resources and workforce training arenas, Alch (2000) described the need for different approaches to supervision in a Millennial-dominated organization compared to a Boomer-dominated one, with greater emphasis on teamwork and group performance, and respect for leaders based on expertise, not rank or tenure. Tucker (2006) wrote specifically about the collaborative learning preferences of Millennials, and that professors must understand the cultural context of their students in order to best foster their academic success. Clearly, community college students as products of three such diverse generations may have differing 
views on what specific academic behaviors are appropriate or inappropriate, ethical or unethical, as they move through their college experiences.

Opposition to generational theory. Not all who study or comment on history or social science agree with the analyses of Strauss and Howe $(1991,1997)$, although significant opposition has not been found in the peer- reviewed literature. In his online publication Duck! and Gather, Peter Savich (2003) critiqued Strauss and Howe's identification of awakening cycles. Pointing to set-backs in the achievement of cycle movements (e.g., abolition and the labor movement) as evidence of a flawed theoretical framework, Savich proposed his own organizational framework for world history, for which no subsequent supporting discussion has been found.

Various others have disputed the exact generational boundaries defined by Strauss and Howe $(1991 ; 1997)$. Much of this discussion has also occurred outside of the peer-reviewed environment, as on the website FreeRepublic.com, or in news media publications. Writing for the Sun News of Myrtle Beach, SC, Zaslow (2004) discussed the considerable differences between the attributes and values of those born at either end of the Boom generation, and noted that the boundaries of the Boom generation as defined by Strauss an Howe differ from those defined by demographers: 1943 versus 1946, and 1960 versus 1964.

Strauss and Howe (1991) did not dispute that their generational boundaries differed from those defined by others, in large part because theirs were based on defining moments of history, not on birth rates. This methodology and rationale has provided a meaningful context within which to consider findings such as those of researchers Diekhoff and his team (1996), who noted differences in how students in 
1994, compared with those in 1984, neutralized, or justified, their cheating: "It appears that 1994's students are more cognizant of the immorality of cheating, but care less!" [exclamation in original] (p. 492).

\section{Summary and Hypotheses}

"The bad news is that cheating is rampant....The good news is that the study of cheating is providing insight not only into these alarming statistics but also into the social contexts and psychological processes that influence cheating behavior" (Jordan, 2003, p. 216). Further study may help educators and academic administrators to understand how differences in students' cheating may be rooted more in very fundamental changes in societal attitudes than in their loss of moral values.

Major agreements in the literature. Studies have shown that students continue to cheat in college. Certain student characteristics have been repeatedly linked to academic cheating (usually self-reported); those most commonly reported, however, such as gender and age, have revealed some significant findings with small to moderate effect sizes. Findings from a number of studies have suggested that level of moral development has been related to students' self-reported cheating behavior, and that levels of moral development have been impacted more by experience in higher education than by age.

Several studies have also shown that the frequency of different forms of cheating has been changing, in part because technological advances have changed the tools and methods available to assist in cheating. Studies have further suggested that members of different generational cohorts, as college students, bring differing attitudes, values, and behaviors to their classrooms. 
Major disagreements and gaps in the literature. Researchers have been inconsistent in the academic behaviors defined as cheating, including leaving that definition unspecified, and have varied considerably in both the organizational framework used to describe cheating and the instruments used to measure it. Without a clear definition of the behaviors in question, even those relationships which have been well-established about academic cheating have been of limited value in application.

Having found significant disagreement in faculty and students' evaluations of behaviors as cheating, Higbee and Thomas (2002) noted that students may be accused of cheating when they believed they were using acceptable study strategies or using legitimate assistance. "It is imperative that educators conduct further studies to explore how students and faculty define academic honesty and share their findings with both groups" (Discussion section, \7).

Studies have also failed to consistently demonstrate strong links between various student characteristics that might prove useful in application towards the improvement of academic integrity. Also, although researchers such as Whitley (1998) have acknowledged that "older research may have limited applicability to the current generation of college students" (p. 236), little attention has been given to the potential relationship of cheating, or the activities considered to be cheating, to the generational membership of students, or the zeitgeist.

Instrumentation used in the study of cheating has not reached a level where replication has produced a commonly-accepted measure; few studies have used the same instruments as earlier studies, and few have reported reliability and validity 
estimations. While the continued refinement of instruments over time may have provided more detailed information in each subsequent study, the lack of a commonlyaccepted instrument has hampered the ability to make valid comparisons over time, among different types of students, or examining different related variables.

Finally, there has been little research describing cheating in the community college setting. The vast majority of studies on cheating have been conducted in fouryear settings.

Hypotheses. The following hypotheses aligned with the research questions are posited:

1. Community college students will differ by generation in their evaluation of academic activities as cheating. Specifically, Millennials and Gen Xers will be less likely than Baby Boomers to evaluate all types of academic activities as cheating.

The works of Howe and Strauss $(2000,2003)$ have suggested that generational differences in their evaluation of academic activities as cheating may be particularly evident in practices involving team work, support of others, and use of technology. Therefore, it is hypothesized that Millennial and Generation X students will evaluate academic activities as cheating less strongly Baby Boomer students, on each scale of cheating.

2. The generational differences in students' evaluation of academic activities as cheating will decrease with greater college experience. Specifically, it is hypothesized that Millennials and Generation X students with higher levels of college experience, compared to those with lower levels of college experience, 
will differ less from Baby Boomers in their evaluation of all types of academic activities as cheating.

The conclusions of Rest (1994) and Whitley (1998) have suggested that higher levels of college experience, leading to higher levels of moral development, may reduce variation among generations in their evaluations of academic activities as cheating. Therefore, it is hypothesized that Millennial and Generation X students with higher levels of college experience, compared to those with lower levels of college experience, will differ less from Baby Boomers in their evaluation of academic activities as cheating on each scale.

3. Gender differences in students' evaluation of academic activities will vary by generation.

Crown and Spiller's meta-analysis (1998) suggested that differences by gender in students' evaluation of academic activities as cheating may be found among Boomers, with men rating more types of academic activities as not cheating or less severe cheating than women, but that such differences may diminish among Generation Xers and Millennials. Therefore, it is hypothesized that Millennial and Generation X students will not vary by gender in their evaluation of academic activities as cheating on any scale, but that Baby Boomer generation male students will evaluate academic activities less strongly as cheating than Baby Boomer female students on all scales.

4. Students' evaluation of academic activities as cheating will vary with program of study. Specifically, within each generation of students, those enrolled in Business/Administrative Support/Information Systems Technology and 
Science/Health Professions will evaluate academic activities less strongly as cheating than those enrolled in Liberal Arts/General Studies/Creative Arts. Various studies have found differences among students in their definition of cheating based on academic program of study (McCabe \& Trevino, 1995; Roberts et. al., 1997). These works have suggested that students in business and science may evaluate fewer academic activities as cheating, or as less severe forms of cheating, than students in other programs of study. Therefore, it is hypothesized that, in each generation of students, those enrolled in Business/Administrative Support/Information Systems Technology and Science/Health Professions will evaluate academic activities less strongly as cheating than those enrolled in Liberal Arts/General Studies/Creative Arts.

5. The generational differences in students' evaluation of academic activities as cheating will not vary with the extent to which their personal morality is grounded in a religious belief system.

The relatively few studies that have examined religion as a correlate of cheating (Crown \& Spiller, 1998; Graham, Monday, O’Brien, Steffen, 1994; Whitely, 1998) provide conflicting suggestions about how the grounding of students' personal morality in a religious belief system may influence their evaluation of academic activities as cheating. Therefore, the hypothesis posited is non-directional.

Contributions of this study. This study will develop an organizational framework and instrument for the study of cheating that purposefully represents the wide array of cheating activities now available to students, including Internet and new technologic capabilities. This instrument will provide for scale scoring of important clusters of cheating activities. 
This study will also describe differences in the activities that are defined as cheating by students of different generations. By linking the often-examined student characteristics of age with the broader context of generational membership, and factoring in students' exposure to prior college coursework which has been related to level of moral development, this study will provide insights into shared attitudes and values among generational cohorts of students.

Finally, by using the setting of the community college, this study will contribute to closing the significant gap between the percentage of undergraduate college students who attend community colleges and the amount of higher education research conducted at the community college level, what Pascarella and Terenzini have described as an "empirical black hole" (1998, Importance, ף 2). The insights derived from this study will serve to assist community college faculty, staff and administrators in the design of policies and strategies to more effectively promote academic integrity on their campuses, and facilitate the achievement of their goals of values development and the preparation of students for effective, productive participation in society. 


\section{CHAPTER III}

\section{Methodology}

This chapter will describe the methodology used in this study. The design, population and sample, procedure, instrumentation, data analysis, protection of human subjects, and limitations will be described.

\section{Research Questions}

Based on the review of the literature, the following research questions were posed:

1. Do community college students differ by generation (Boomer, Generation X, and Millennial) in their evaluation of academic activities as cheating?

2. Does the generational difference among community college students in their evaluation of academic activities as cheating vary with college experience?

3. Do the gender differences among community college students in their evaluation of academic activities as cheating vary with generation?

4. Do community college students differ by program of study in their evaluation of academic activities as cheating?

5. Does the generational difference among community college students in their evaluation of academic activities as cheating vary with the extent to which their personal morality is grounded in a religious belief system? Research Design

The research design originally planned to answer the first four questions was a non-experimental comparative design with a $3 \times 4 \times 2 \times 4$ factorial analysis. The 
independent variables were the generational classification of students at three levels (Boomer, Generation X, and Millennial), college experience at four levels, gender at two levels, program of study at four levels, and degree to which personal morality is grounded in a religious belief system at four levels. This was later amended to a $3 \times 2$ $\times 2 \times 4$ factorial analysis when the college experience variable was collapsed to two levels, and the category Other in the program of study variable was dropped from analysis. The final research question was addressed using a $3 \times 4$ factorial analysis, with the generational classification of students at three levels and extent to which their personal morality is grounded in a religious belief system at 4 levels. A researcherdeveloped instrument called the Definitions of Cheating Scale (DoCS) assessed students' classification of specific activities as cheating in several different areas of academic activities; students' mean scores on each scale were the dependent variables. Table 1 presents the independent and dependent variables used in this study.

Table 1

Study Variables

\begin{tabular}{ll}
\hline \multicolumn{1}{c}{ Independent Variables } & Dependent Variables \\
\hline Generational Classification & DoCS Scale Score \#1 \\
College Experience & DoCS Scale Score \#2 \\
Gender & DoCS Scale Score \#3 \\
Program of Study & DoCS Scale Score \#4 \\
Extent to Which Personal Morality is \\
Grounded in a Religious Belief System
\end{tabular}


Population and Sample

The population for this study was U.S. community college students. The sample consisted of Virginia community college students enrolled at a mid-sized, suburban/rural institution during the 2005-2006 academic year. Although community colleges nationwide enroll $47 \%$ to $57 \%$ of all black, Hispanic, Asian/Pacific Islander, and Native American U.S. undergraduate students (AACC, 2007), the sample community college served a community of minimal ethnic diversity, and its ethnic demographics reflected its community (VCCS, 2006b). Given this lack of ethnic diversity, and the fact that attitudes towards cheating have not been shown to differ based on students' ethnicity (Sutton \& Hubs, 1995), the ethnic demographics of the sample were not evaluated. Using the birth-year designations and names for generations as defined by Howe and Strauss (2000) (Boomers, born 1943-1960; Generation X, born 1961-1981, and Millennials, born 1982-2000), the Virginia Community College System enrollments of fall 2005 are shown in Table 2 below.

\section{Table 2}

Generational Distribution of VCCS Students Fall, 2005

\begin{tabular}{cc}
\hline Generation & Percent \\
\hline Boomer & 10.8 \\
Generation X & 36.1 \\
Millennial & 53.1 \\
\hline
\end{tabular}

Note. Calculated excluding data reported of students under age 17 , predominantly enrolled in high school based dual-enrollment classes 
In order to capture a wide diversity of students by age, gender, and previous college experience, a purposeful cluster sampling technique was used (shown in Appendix B). Classes, as selected by students, were the unit of sampling. Because Boomers represented the smallest segment of the community college student body, at about $11 \%$ (VCCS, 2006a), the sampling strategy was designed to maximize the likelihood of including at least 100 Boomers in the sample. At an average class size of 20,50 classes were predicted to be needed to generate 100 Boomer participants as desired for data analysis; 10 additional classes were included to allow for nonparticipation and other factors which may have reduced the sample size. Classes were selected for inclusion in the sample purposefully to include morning, afternoon, and evening classes each day of the week (except Sunday when no credit classes were offered), and at the developmental, freshman (100-series) and sophomore (200-series) levels. Again, this sampling strategy was employed to maximize the likelihood of reflecting the generational diversity of the overall enrollments with sufficient numbers to achieve the desired power in statistical analysis.

At the community college where data was collected, a unique section number was computer-generated for each separate class scheduled for a semester. Class sections offered during the semester of data collection were classified as to their status (developmental, freshman, or sophomore) and schedule (day of the week and morning, afternoon, or evening). A table of random numbers was then used to select the individual classes required to satisfy the sampling matrix . 


\section{Instrumentation}

A questionnaire called the Definitions of Cheating Survey, or DoCS (Appendix C) was developed to measure participants' classification of specific activities as cheating, generational membership, number of college courses previously completed, gender, and the extent to which persona morality is grounded in a religious belief system. Items to determine respondents' status on independent variables appeared at the beginning and end of the questionnaire. Generational membership was measured by respondents' selection of their current age group at the beginning of the survey. Respondents were also asked at the beginning of the survey to designate their gender and indicate their academic program of study from one of four groupings. The number of previously completed college courses was assessed at the end of the survey, again with four ranges from which students were asked to select. For a typical community college associate's degree, 60 to 65 credits are generally required. Therefore, college experience were grouped into ranges of $0-15$ credits, $16-30$ credits, $31-45$ credits, and 46 or more credits. Finally, participants were asked to rate the extent to which their personal morality is grounded in a religious belief system, using a four point Likert-type scale.

The majority of the academic activities selected for inclusion in the pilot DoCS were drawn from the literature on cheating, as were the organizing scales, as shown in the blueprint in Table 3. The activities not drawn directly from previous studies on cheating were either interpolated from the team affiliation behaviors of the Millennial generation documented by Howe and Strauss (2003), or had only recently been reported by the press (Paul, 2004). A Likert-type scale was developed with 
which students were asked to judge the extent to which they agreed that each academic activity represented cheating.

Table 3

Blueprint for Construction of the Definitions of Cheating Scale

\begin{tabular}{lc}
\hline \multicolumn{1}{c}{ Category of Cheating } & Number of Items \\
\hline Exams/Tests/Quizzes & 6 \\
Homework/Lab Reports/Assignments & 6 \\
Papers & 6 \\
Assisting Others & 6 \\
Internet/Technology & 6 \\
\hline
\end{tabular}

\section{Protection of Human Subjects}

The study proposal was reviewed and approved by the Old Dominion University Committee for the Protection of Human Subjects. No information identifying individual subjects was collected during the actual study; identifying information required to match first and second survey completions during the pilot test were destroyed by participants when they submited their completed two-survey envelopes. Students were free to participate or not with no penalty, and without the knowledge of the instructor responsible for the course in which they were enrolled. Pilot Testing and Psychometric Properties

Pilot testing of the DoCS allowed not only for estimation of test-retest reliability, but also for the enhancement of validity. In addition to the DoCS, pilot 
study participants were asked to complete the Survey Instrument Feedback questionnaire (Appendix D), which solicited ratings on the ease of understanding the purpose, directions, and individual survey items, requested suggestions on how any confusing items might be clarified, and determined the time-burden for completion of the survey. The results of the Survey Instrument Feedback questionnaire were reviewed to determine any significant concerns with the questionnaire, with individual items, or in the data collection procedure. Analysis of students' participation rate in the pilot study was conducted to determine if significant numbers were opting out and thus creating an additional limitation to the generalizability of the study. Finally, data analysis was performed using the pilot test results to ensure that the research questions could be adequately answered.

The pilot test was conducted by requesting permission of faculty teaching five different classes, two morning/freshman, one afternoon/developmental level, and two evening/sophomore level; at an average class size of 20 , this procedure was expected to secure a total sample of about 100 for the pilot test. Students in these classes were asked to complete both the DoCS instrument and the Survey Instrument Feedback questionnaire (Appendix D) twice, with seven days elapsing between measures.

At each pilot test data collection session, a proctor arrived at the previously agreed-upon time, and the instructor was asked to leave the room. The proctor read a standardized set of instructions including the fact that she/he would not be allowed to interpret anything on the survey (Appendix E). Survey packets including a letter to participants (Appendix F), DoCS surveys, Survey Instrument Feedback forms were distributed. 
Students were free to decline participation, and their completion of the survey was construed as consent to participate. Students were asked to seal their completed first survey in an envelope and place that envelope into a larger envelope with their initials on it; this identifying information was requested of participants only to match the first survey with the repeat survey. During the second data collection period, students retrieved their initialed envelopes, removed the first survey and placed both surveys into one blank envelope. Pilot test participants then destroyed their identifying information upon submission of their envelope containing two surveys.

Factor analysis was conducted on the pilot test data, and items which did not load to single scales were removed. Correlation coefficients (Pearson's $r$ ) were calculated between scores on the first and second administration of the DoCS to estimate test-retest reliability for those items which were ultimately retained in the final DoCS instrument. Coefficient alpha was then determined for each of the scale scores derived for the DoCS. This analysis estimated internal consistency, indicating the degree of homogeneity among the items, which is one of the most commonly utilized measures of reliability (McMillan, 2004).

Validity of the DoCS was enhanced through the construction of the instrument based on the literature. The representation in the literature of the various academic behaviors included in the DoCS is summarized in Appendix A. Validity was further enhanced through review of the DoCS by college faculty and administrators experienced in instruction and student affairs. Factor analysis of the pilot test data provided additional evidence for the validity of the a priori scales utilizing an appropriate rotation (Costello \& Osborne, 2005). In previous studies, not all items 
representing specific behaviors potentially construed as cheating have proven to contribute significantly to factorial validity (Angell, 2006; Bernardi et al., 2004). Data Collection Procedure

Faculty teaching classes selected according to the sampling matrix (Appendix B) were asked for permission to distribute survey materials to their students during a class meeting. A proctor arrived to the class at the previously agreed-upon time, and the instructor was asked to leave the room. The proctor read a standardized set of instructions including the fact that she/he would not be allowed to interpret anything on the survey (Appendix H). Survey packets including a letter to participants (Appendix I), DoCS surveys and pencils were distributed. Students were free to decline participation, and their completion of the survey was construed as consent to participate. No identifying information was requested of participants.

Following data collection, in return for their cooperation, participating faculty were offered an electronic file of a presentation about academic integrity which they may choose to use during a subsequent class session, and a copy of the study's findings upon completion of the study.

\section{Data Analysis}

The number of surveys completed was compared to the number distributed to determine the participation rate in each class. Participation rates by class were examined for any trends of significance that may pose additional limitations to the interpretation of study findings.

Descriptive statistics were calculated for each of the independent and dependent variables, and reported for each of the DoCS items as well as summary 
scale scores. Respondents' ratings on each activity were converted to a numerical value ("Strongly Disagree" = 1; "Disagree" = 2; "Agree" = 3; and "Strongly Agree" $=4$ ), and the values for each of the six activities comprising each scale were averaged. Thus, scores on each scale ranged from 1.0 to 4.0 . These results were examined using factor analysis to determine the variance within each scale. In the absence of sufficient variance within each scale, the ability to determine a relationship between any of the independent variables and the dependent variable scale scores would have been weakened. Data were examined for any interactions between or among variables.

Data were then subjected to two separate factorial MANOVAs. The first MANOVA included the factors of generation, college experience, gender, and program of study. The second MANOVA included the factors of generation and extent to which personal morality is grounded in a religious belief system. For each of the MANOVAs, the dependent variables were the DoCS scale scores. This statistical model tested both the main effect of generation and possible interactions. Univariate follow-up and post hoc contrasts were employed to isolate significant effects associated with specific dependent variables and levels of the independent variables when the omnibus multivariate test reached statistical significance. As noted above in reference to validity, factor analysis was used to provide a priori evidence of the validity of the scales (Costello \& Osborne, 2005). 


\section{CHAPTER IV}

\section{Results}

This section will begin with a description of the pilot study, factor analysis of the Definitions of Cheating Scale (DoCS) instrument, and revisions made to the DoCS based on the factor analysis. Then, demographics will be presented for the study sample, followed by descriptions of individual item responses and the factor analysis of the revised DoCS. Finally, the results of statistical testing of the research questions will be presented.

\section{Pilot Study}

In order to allow for estimation of test-retest reliability, as well as for the enhancement of content validity, a pilot study was conducted. Pilot study participants were asked to complete the DoCS (Appendix C) on two occasions, one week apart, and to complete the Survey Instrument Feedback questionnaire (Appendix D). The Survey Instrument Feedback questionnaire solicited ratings on the ease of understanding the purpose, directions, and individual survey items, requested suggestions on how any confusing items might be clarified, and determined the timeburden for completion of the survey.

Pilot study sample demographics. The pilot study was conducted in five class sections, randomly selected among morning, afternoon, and evening offerings of developmental (remedial), freshman, and sophomore level courses. A total of 78 testretest survey pairs were obtained. The pilot study sample was nearly $70 \%$ Millennials, $25 \%$ Generation-Xers, and $6 \%$ Baby Boomers. There were $67 \%$ females and $33 \%$ 
males. The predominant level of college experience was $16-30$ credits completed, at $36.7 \%$, followed by $0-15$ credits at $29.1 \%, 46+$ credits at $19.0 \%$, and finally $39-45$ credits at $15.2 \%$.

Liberal Arts/General Studies/Creative Arts majors dominated among the Millennials, shown in Table 4. However, Business/Administrative Support/ Information Systems Technology and Science/Health Professions majors dominated among Generation-Xers and Baby Boomers.

Table 4

Pilot Study Distribution by Generation and Program of Study

\begin{tabular}{|c|c|c|c|c|c|c|c|c|}
\hline & \multicolumn{2}{|c|}{ Millennial } & \multicolumn{2}{|c|}{ Gen X } & \multicolumn{2}{|c|}{ Baby Boomer } & \multicolumn{2}{|c|}{ Total } \\
\hline & $\mathbf{n}$ & Percent & $\mathrm{n}$ & Percent & $\mathbf{n}$ & Percent & $\mathrm{n}$ & Percent \\
\hline $\begin{array}{l}\text { Liberal Arts, General } \\
\text { Studies, Creative Arts }\end{array}$ & 26 & 33.3 & 1 & 1.3 & 0 & 0 & 27 & 34.6 \\
\hline $\begin{array}{l}\text { Business, } \\
\text { Administrative } \\
\text { Support, Information } \\
\text { Systems Technology }\end{array}$ & 15 & 19.2 & 9 & 11.5 & 2 & 2.6 & 26 & 33.3 \\
\hline $\begin{array}{l}\text { Science, Health } \\
\text { Professions }\end{array}$ & 10 & 12.8 & 7 & 9.0 & 2 & 2.6 & 19 & 24.4 \\
\hline Other & 3 & 3.8 & 2 & 2.6 & 1 & 1.3 & 6 & 7.7 \\
\hline Total & 54 & 69.2 & 19 & 24.4 & 5 & 6.4 & 78 & 100 \\
\hline
\end{tabular}

Pilot study analysis. Responses to the Survey Instrument Feedback questionnaire revealed no significant respondent issues with the DoCS. No student who was asked to participate in the pilot study declined. 
Factor analysis was conducted on the DoCS using direct oblim rotation, which assumes that correlation exists among the scales. To achieve the most simple structure, items that loaded on more than one scale were successively eliminated. Through this process, it became evident that the Technology scale did not hang together; rather, items about the use of technology in different types of cheating, such as during exams, loaded with other items about exam cheating. Additionally, the items in the Assisting Others scale loaded on three different factors, and were therefore eliminated.

What emerged from the factor analysis were four scales, which were labeled Exam/Paper Cheating, Fabrication, Shortcuts, and Excuses. Fourteen of the original 30 DoCS items were retained in these four scales, and eleven new items were created, resulting in a revised DoCS instrument with a total of 25 items divided into the four scales. The revised DoCS is shown in Appendix H.

Because the instrument was revised, the test-retest reliability coefficients were not obtained by scale. Rather, the stability coefficients will be reported for only the retained items. The reliability of the instrument will be described after reporting the results of the second factor analysis.

Sample Demographics

Sampling of 60 class sections for the actual study yielded a total useable sample of 650 , as opposed to the 1000 that was projected. This occurred because the mean class size was 10.9 as opposed to the expected 20. Participants ranged in birthyear from 1933 to 1990. 
Generation. Millennial generation students comprised $71.6 \%$ of the sample, with the three most common birth-years being 1988 ( $n=124,20 \%$ of sample), 1987 $(n=114,18 \%$ of sample), and $1986(n=90,14 \%$ of sample). As shown in Table 5 , students of Generation X comprised $23.6 \%$ of the sample, and Baby Boomers $4.6 \%$.

Table 5

Sample Distribution by Generation

\begin{tabular}{lcccccccc}
\hline & \multicolumn{2}{c}{ Millennial } & \multicolumn{2}{c}{ Generation X } & Baby Boomer & \multicolumn{2}{c}{ Total } \\
\cline { 2 - 8 } & $\mathrm{n}$ & Percent & $\mathrm{n}$ & Percent & $\mathrm{n}$ & Percent & $\mathrm{n}$ & Percent \\
\hline Total & 465 & 71.6 & $\mathbf{1 5 4}$ & 23.6 & 30 & 4.6 & 649 & 100 \\
\hline
\end{tabular}

Note: 1 case missing data

College experience. As shown in Table 6, the greatest percentage of students in each generation reported having completed 15 or fewer college credits: $38.9 \%$ of Millennials, $31.1 \%$ of Gen Xers, and $32.1 \%$ of Baby Boomers. A trend was evident of decreasing numbers of students having completed each subsequent level of college experience. More than half of each generation reported having completed 30 or fewer college credits: $70 \%$ of Millennials, $59.6 \%$ of Gen Xers, and $53.6 \%$ of Baby Boomers. 
Table 6

College Experience Distribution by Generation

\begin{tabular}{lcccccccc}
\hline & \multicolumn{2}{c}{ Millennial } & \multicolumn{3}{c}{ Generation X } & Baby Boomer & \multicolumn{2}{c}{ Total } \\
\cline { 2 - 9 } & $\mathrm{n}$ & Percent & $\mathrm{n}$ & Percent & $\mathrm{n}$ & Percent & $\mathrm{n}$ & Percent \\
\hline $0-15$ credits & 174 & 27.8 & 47 & 7.5 & 9 & 1.4 & 230 & 36.7 \\
$16-30$ credits & 139 & 22.2 & 43 & 6.9 & 8 & 1.3 & 190 & 30.3 \\
$31-45$ credits & 60 & 9.6 & 20 & 3.2 & 5 & 0.8 & 85 & 13.6 \\
$46+$ credits & 74 & 11.8 & 41 & 6.4 & 8 & 1.3 & 122 & 19.5 \\
Total & 447 & 71.3 & 150 & 23.9 & 30 & 4.8 & 627 & 100 \\
\hline
\end{tabular}

Note: 23 cases missing data

Gender. Overall, as also shown in Table 7, 64\% of respondents were female, and $36 \%$ were male. However, the percentage of women within each generational group rose with age, from $60 \%$ females among Millennials, to $71 \%$ females in Generation X, to $76 \%$ females among Baby Boomers.

Table 7

Gender Distribution by Generation

\begin{tabular}{lcccccccc} 
& \multicolumn{2}{c}{ Millennial } & \multicolumn{2}{c}{ Generation X } & Baby Boomer & \multicolumn{2}{c}{ Total } \\
\cline { 2 - 9 } & $\mathrm{n}$ & Percent & $\mathrm{n}$ & Percent & $\mathrm{n}$ & Percent & $\mathrm{n}$ & Percent \\
& 280 & 43.1 & 110 & 16.9 & 23 & 3.5 & 413 & 64 \\
Male & 185 & 28.5 & 44 & 6.7 & 7 & 1.1 & 236 & 36 \\
Total & 465 & 71.6 & 154 & 23.6 & 30 & 4.6 & 649 & 100 \\
\hline
\end{tabular}

Note: 1 case missing data 
Program of study. For clarity of discussion, from this point forward, the categories of programs of study will be referred to with abbreviated labels: Liberal Arts will be used to refer to the cluster of Liberal Arts, General Studies, and Creative Arts; Business will be used to refer to the cluster of Business, Administrative Support Technology, and Information Systems Technology, and Sci/Health will be used to refer to the cluster of Science and Health Professions. As shown in Table 8, among Millennials, Liberal Arts majors predominated for both men and women, followed by Sci/Health, Business, and Other for women; for men, Business ranked second, followed by Sci/Health and Other. Among Generation X women, Sci/Health strongly predominated, followed by Business, then Liberal Arts, and then Other; for Generation $\mathrm{X}$ men, distribution among the four program areas of study was nearly uniform. Among Baby Boomer students, women's programs of study were almost uniformly distributed among Liberal Arts, Sci/Health, and Business, while Other programs dominated for men. Programs of study indicated by those who responded "Other" were most frequently listed as Education $(n=17)$, Electrical Technology $(n=8)$, and Heating/Ventilation/Air Conditioning $(n=5)$; because of this wide variety and the relatively low number in the category, the category of Other program of study was dropped from subsequent analyses (treated as missing data on this variable). 
Table 8

Program of Study Distribution by Generation

\begin{tabular}{lcccccccc}
\hline & \multicolumn{2}{c}{ Millennial } & \multicolumn{2}{c}{ Generation X } & \multicolumn{2}{c}{ Baby Boomer } & \multicolumn{2}{c}{ Total } \\
\cline { 2 - 8 } & $\mathrm{n}$ & Percent & $\mathrm{n}$ & Percent & $\mathrm{n}$ & Percent & $\mathrm{n}$ & Percent \\
\hline Liberal Arts & 204 & 31.4 & 28 & 4.3 & 6 & 0.9 & 238 & 36.7 \\
Business & 87 & 13.4 & 34 & 5.2 & 8 & 1.2 & 129 & 19.9 \\
Sci/Health & 140 & 21.6 & 72 & 11.1 & 10 & 1.5 & 222 & 34.2 \\
Other & 34 & 5.2 & 20 & 3.1 & 6 & 0.9 & 60 & 9.2 \\
Total & 465 & 71.6 & 154 & 23.7 & 30 & 4.6 & 649 & 100 \\
\hline
\end{tabular}

Note: 1 case missing data

Personal morality as grounded in a religious belief system. Most students at each generational level, as depicted in Table 9, either agreed or strongly agreed that their personal morality was grounded in a religious belief system. Specifically, $62.6 \%$ of Millennials, $70.3 \%$ of Gen Xers, and $80 \%$ of Baby Boomers either agreed or strongly agreed with this statement. 
Table 9

Personal Morality Grounded in a Religious Belief System Response Distribution by Generation

\begin{tabular}{lcccccccc}
\hline & \multicolumn{2}{c}{ Millennial } & \multicolumn{2}{c}{ Generation X } & \multicolumn{2}{c}{ Baby Boomer } & \multicolumn{2}{c}{ Total } \\
\cline { 2 - 9 } & $\mathrm{n}$ & Percent & $\mathrm{n}$ & Percent & $\mathrm{n}$ & Percent & $\mathrm{n}$ & Percent \\
\hline Strongly Disagree & 71 & 11.5 & 26 & 4.2 & 2 & 0.3 & 99 & 16.0 \\
Disagree & 94 & 15.2 & 18 & 2.9 & 4 & 0.6 & 116 & 18.7 \\
Agree & 178 & 28.8 & 67 & 10.8 & 11 & 1.8 & 256 & 41.3 \\
Strongly Agree & 98 & 15.8 & 37 & 6.0 & 13 & 2.1 & 148 & 23.9 \\
Total & 441 & 71.2 & 148 & 23.9 & 30 & 4.8 & 619 & 100 \\
\hline
\end{tabular}

Note: 31 cases missing data

\section{Factor Analysis}

Factor analysis was conducted on the Definitions of Cheating Scale (DoCS) in the same manner as during the pilot study, using direct oblim rotation, which assumes that correlation exists among the scales. Because prior analysis of the pilot study data suggested four scales, the analysis was constrained to four scales. The pattern matrix supported the a priori four factors. Each of the items had a factor loading of .30 or higher on the expected factors; however, four items had strong loadings on more than one scale, and therefore were eliminated. Thus, this process resulted in the retention of 21 items, ranging from 4 to 7 per factor. Three of the four factors each had eigenvalues greater than 1.0 (Exams/Papers, Shortcuts, and Excuses), while the fourth factor had an eigenvalue of .966 (Fabrication). Together, the four factors together 
explained $70.72 \%$ of the overall variance. Details of the pattern matrix analysis and reliability estimates are shown in Appendix K.

Having determined which of the items from the DoCS pilot study would be retained for the final exploration of the research questions, those 12 items were then analyzed for their test-retest correlation during the pilot study. As shown in Table 10, Pearson's $r$ calculations ranged from .357 to .920 , with a mean of .668 , all significant at $p<.01$.

Table 10

Test-Retest Coefficients for DoCS Items Retained from Pilot Study

\begin{tabular}{ccc}
\hline Pilot Item Code & Final Item Code & Pearson's $r$ \\
\hline E2 & EP2 & $.775^{*}$ \\
E4 & E4 & $.575^{*}$ \\
E6 & EP1 & $.579^{*}$ \\
H5 & F4 & $.357^{\star}$ \\
H6 & E5 & $.578^{\star}$ \\
P1 & S1 & $.876^{*}$ \\
P4 & E2 & $.664^{*}$ \\
P5 & F5 & $.484^{*}$ \\
P6 & EP6 & $.740^{*}$ \\
T1 & EP3 & $.920^{*}$ \\
T2 & EP4 & $.740^{*}$ \\
T6 & EP5 & $.732^{*}$ \\
\hline${ }^{*} p<.01$ & &
\end{tabular}

Cronbach's alpha $(\alpha)$, another measure of reliability, was calculated for each of the DoCS scales using all items retained for each scale following the factorial analysis. Cronbach's alpha coefficients were .899 for the Exams/Papers scale, .827 for the Fabrication scale, .846 on the Shortcuts scale, and .935 on the Excuses scale. 
Descriptive Statistics for DoCS Responses

Individual item descriptive statistics (mean, standard deviation, and percentage response by category) were computed for each item by scale and are displayed in Appendix L. Out of 650 useable surveys, the number of individual item responses ranged from 626 to 650 , with a higher rate of missing data for the Shortcuts and Excuses scales. Comparisons of the mean scale scores are shown in Table 11 Exams/Papers (EP) scored the highest, indicating that these items were rated most strongly as cheating by students overall, and had the smallest standard deviation $(M=$ 3.76, $S D=.406, \alpha=.899$ ). Fabrication (F) ranked next highest in being rated as cheating $(M=3.11, S D=.679, \alpha=.827)$, followed by Excuses $(\mathrm{E})(M=2.97, S D=$ $.747, \alpha=.935)$. Shortcuts(S) were rated the least strongly as cheating. $(M=2.42, S D=$ $.717, \alpha=.846)$.

Table 11

DoCS Scales Descriptive Statistics, All Scales

\begin{tabular}{lcccc}
\hline \multicolumn{1}{c}{ Scale } & $\mathrm{n}$ & $\mathrm{M}^{*}$ & $\mathrm{SD}$ & $\alpha$ \\
& & & & \\
\hline Exams/Papers (EP) & 650 & 3.76 & .406 & .899 \\
Fabrication (F) & 650 & 3.11 & .679 & .827 \\
Shortcuts (S) & 632 & 2.42 & .717 & .846 \\
Excuses (E) & 631 & 2.97 & .747 & .935 \\
\hline
\end{tabular}

* Based on four-point scale 
The factor analytic results supported the retention of all seven items on the Exams/Papers (EP) scale; descriptive statistics for the EP scale are shown in Table 12. On this scale, item EP5 was rated the most strongly as cheating $(M=3.86, S D=3.98)$; this item read "Accessing an instructor's or college computer system to alter grades." Item EP4 was rated the least strongly as cheating $(M=3.68, S D=.550)$, although this rating still demonstrates a high level of agreement that the activity represents cheating: "Storing answers to a test in a calculator or Personal Digital Assistant (PDA)."

Table 12

DoCS Exams/Papers Scale Descriptive Statistics

\begin{tabular}{lccc}
\hline \multicolumn{1}{c}{ Item } & $\mathrm{N}$ & Mean & $\begin{array}{c}\text { Std. } \\
\text { Deviation }\end{array}$ \\
\hline $\begin{array}{l}\text { EP1. Changing answers on a graded } \\
\text { exam /test/quiz and reporting a } \\
\text { grading error }\end{array}$ & 644 & 3.71 & .647 \\
$\begin{array}{l}\text { EP2. Copying from another student } \\
\text { during an exam/test/quiz }\end{array}$ & 650 & 3.82 & .442 \\
$\begin{array}{l}\text { EP3. Text-messaging during an exam } \\
\text { to get answers }\end{array}$ & 650 & 3.80 & .469 \\
$\begin{array}{l}\text { EP4. Storing answers to a test in a } \\
\text { calculator or Personal Digital }\end{array}$ & 650 & 3.68 & .550 \\
$\begin{array}{l}\text { Assistant (PDA) } \\
\begin{array}{l}\text { EP5. Accessing an instructor's or } \\
\text { college computer system to alter } \\
\text { grades }\end{array}\end{array}$ & 650 & 3.86 & .398 \\
$\begin{array}{l}\text { EP6. Copying a paper written by } \\
\text { another student }\end{array}$ & 649 & 3.72 & .537 \\
$\begin{array}{l}\text { EP7. Sending/ storing cell phone } \\
\text { photos of exam/test/quiz pages for } \\
\text { others' use }\end{array}$ & 648 & 3.74 & .527 \\
\hline
\end{tabular}


The overall mean scale score on the Exams/Papers scale was $3.76(n=650)$, with a standard deviation of .406 and Cronbach's alpha of .899. The Exams/Papers scale had the highest overall mean of all of the scales, and the smallest standard deviation.

In the Fabrication (F) scale, two items not supported by the factor analytic results were deleted; descriptive statistics for the remaining four items are shown in Table 13. On this scale, the item most strongly rated as cheating was F5 ( $M=3.25$, $S D=.793$ ): "Adding fake or unused references to a paper to expand the bibliography." The item rated least strongly as cheating was F2 $(M=3.03, S D=.872)$ : "Having someone else make a required poster because his work is neater."

Table 13

DoCS Fabrication Scale Descriptive Statistics

\begin{tabular}{lccc}
\hline \multicolumn{1}{c}{ Item } & $\mathrm{N}$ & Mean & $\begin{array}{c}\text { Std. } \\
\text { Deviation }\end{array}$ \\
\hline $\begin{array}{l}\text { F2. Having someone else make } a \\
\text { required poster because his work is } \\
\text { neater }\end{array}$ & 647 & 3.03 & .872 \\
$\begin{array}{l}\text { F4. Changing or creating data for } \\
\text { homework/lab reports/ } \\
\text { assignments }\end{array}$ & 641 & 3.05 & .845 \\
$\begin{array}{l}\text { F5. Adding fake or unused } \\
\text { references to a paper to expand the } \\
\text { bibliography }\end{array}$ & 647 & 3.25 & .793 \\
$\begin{array}{l}\text { F6. Recording activities not actually } \\
\text { completed for class assignments. }\end{array}$ & 643 & 3.12 & .843 \\
\hline
\end{tabular}


The Fabrication scale had an overall mean scale score of $3.11(n=650)$, with a standard deviation of .679 and a Cronbach's alpha of .827 . The Fabrication scale was the second highest overall mean scale score, lower than Exams/Papers but higher than Shortcuts and Excuses, and the second lowest standard deviation.

In the Shortcuts (S) scale, two items were deleted because they were not supported by the results of the factor analysis; descriptive statistics for the remaining four items are shown in Table 14. The means for all items in this scale fell in the range of disagreement that these activities represented cheating $(M<3.0)$. Item S3 was rated most strongly as cheating $(M=2.46, S D=.803)$ : "Watching a movie of a famous book instead of reading it as assigned." Item S1 rated the least strongly as cheating ( $M=2.40, S D=.922)$ : "Submitting a paper you originally completed for a previous class ('recycling')."

Table 14

DoCS Shortcuts Scale Descriptive Statistics

\begin{tabular}{lccc}
\hline \multicolumn{1}{c}{ Item } & $\mathrm{N}$ & Mean & $\begin{array}{c}\text { Std. } \\
\text { Deviation }\end{array}$ \\
\hline $\begin{array}{l}\text { S1. Submitting a paper you originally } \\
\text { completed for a previous class } \\
\text { ("recycling") }\end{array}$ & 631 & 2.40 & .922 \\
$\begin{array}{l}\text { S3. Watching a movie of a famous } \\
\text { book instead of reading it as assigned }\end{array}$ & 626 & 2.46 & .803 \\
$\begin{array}{l}\text { S4. Submitting an assignment you } \\
\text { originally completed for a previous } \\
\text { class ("recycling") }\end{array}$ & 626 & 2.42 & .906 \\
$\begin{array}{l}\text { S5. Reading published summaries or } \\
\text { study guides instead of an assigned } \\
\text { book }\end{array}$ & 629 & 2.41 & .825 \\
\hline
\end{tabular}


The overall mean on the Shortcuts scale was $2.42(n=631)$, with a standard deviation of .717 and a Cronbach's alpha of .846 . This was the lowest overall mean of all of the DoCS scales, and the second largest standard deviation.

All six of the items were retained in the Excuses (E) scale following factor analysis, and descriptive statistics for these items are shown in Table 15. The majority of items (five out of six) on the Excuses scale were not classified as cheating, with mean scores falling below the midpoint of the Likert-type scale $(M<3.0)$. Item E6 was rated most strongly as cheating $(M=3.05, S D=.893)$, and was the only item where the mean fell into the range of classifying the activity as cheating: "Skipping class when your group presentation is scheduled." Item E3 was rated least strongly as cheating $(M=2.87, S D=.866)$ : "Making a false excuse not to meet with your group to work on an assigned project." 
Table 15

DoCS Excuses Scale Descriptive Statistics

\begin{tabular}{llcc}
\hline \multicolumn{1}{c}{ Item } & $\mathrm{N}$ & Mean & $\begin{array}{c}\text { Std. } \\
\text { Deviation }\end{array}$ \\
\hline $\begin{array}{l}\text { E1. Exaggerating personal problems } \\
\text { to take an Incomplete in a course }\end{array}$ & 628 & 2.98 & .868 \\
$\begin{array}{l}\text { E2. Delaying turning in a paper with a } \\
\text { falsified excuse }\end{array}$ & 628 & 2.97 & .851 \\
$\begin{array}{l}\text { E3. Making a false excuse not to } \\
\text { meet with your group to work on an }\end{array}$ & 630 & 2.87 & .866 \\
$\begin{array}{l}\text { assigned project } \\
\begin{array}{l}\text { E4. Delaying taking an exam/test/quiz } \\
\text { with a falsified excuse }\end{array}\end{array}$ & 627 & 2.98 & .848 \\
$\begin{array}{l}\text { E5. Delaying turning in homework/lab } \\
\text { reports/assignments with a falsified } \\
\text { excuse }\end{array}$ & 629 & 2.94 & .834 \\
$\begin{array}{l}\text { E6. Skipping class when your group } \\
\text { presentation is scheduled }\end{array}$ & 629 & 3.05 & .893 \\
\hline
\end{tabular}

The overall mean on the Excuses scale was $2.97(n=632)$, with a standard deviation of 7.47 and Cronbach's alpha of .935. The Excuses scale thus had the second lowest mean of any of the DoCS scales, and the highest standard deviation. Results by Research Question

To address the research questions, two multivariate analyses of variance (MANOVA) were conducted. Rather than analyzing each independent variable separately, the demographic variables were introduced into a single model to check for any significant interactions. The first statistical model included generation and the three demographic or background variables (college experience, gender, and program of study) as independent variables, and the four DoCS scale scores as dependent variables. This model encompassed the omnibus results pertaining to research 
questions one through four. The second statistical model addressed the fifth and final research question. The independent variables were generation and personal morality, and the dependent variables were the four DoCS scale scores.

In light of the small number (30) of Baby Boomers in the final study sample, Wilks' Lambda was used to determine the significance of results, in order to be conservative. Table 16 shows the Wilks' Lambda and $p$ value for each research question. The only omnibus test that reached statistical significance was obtained for the generational variable pertained to the first research question. The main effect for program of study (research question number four) was not statistically significant. The interactions of generation with college experience, gender, and extent to which their personal morality is grounded in a religious belief system were also not statistically significant. 
Table 16

Wilks ' Lambda Values and Significance Levels by Research Question

\begin{tabular}{lcc}
\hline \multicolumn{1}{c}{ Research Question } & Wilks' Lambda & $p$ \\
\hline $\begin{array}{l}\text { 1. Do community college students differ by generation in } \\
\text { their evaluation of academic activities as cheating? }\end{array}$ & 2.674 & $.007^{*}$ \\
$\begin{array}{l}\text { 2. Does the generational difference among community } \\
\text { college students in their evaluation of academic activities } \\
\text { as cheating vary with college experience? }\end{array}$ & .611 & .769 \\
$\begin{array}{l}\text { 3. Does the gender difference among community college } \\
\text { students in their evaluation of academic activities as } \\
\text { cheating vary with generation? }\end{array}$ & & \\
$\begin{array}{l}\text { 4. Do community college students differ by program of } \\
\text { study in their evaluation of academic activities as } \\
\text { cheating? }\end{array}$ & & .1 .143 \\
$\begin{array}{l}\text { 5. Does the generational difference among community } \\
\text { college students in their evaluation of academic activities } \\
\text { as cheating vary with the extent to which their personal } \\
\text { morality is grounded in a religious belief system? }\end{array}$ & .637 \\
\hline * $p<.05$ & & .286 \\
\end{tabular}

Do community college students differ by generation (Boomer, Generation X, and Millennial) in their evaluation of academic activities as cheating? With a Wilks' Lambda value of $2.674(p=.007)$, the MANOVA revealed a significant main effect for generation. The follow-up univariate tests, displayed in Table 17, revealed that there was no difference among community college students in their evaluation of academic activities as cheating on the Exams/Papers scale, $F(2,561)=2.709, p=.011$.

Significant differences were found, however, on each of the remaining scales:

Fabrication, $F(2,561)=8.610, p=.033$; Shortcuts, $F(2,561)=5.749, p=.022$, and Excuses, $F(2,561)=7.096, p=.027$. 
Table 17

Descriptive Statistics and MANOVA Results for Cheating by Generation

\begin{tabular}{|c|c|c|c|c|c|c|c|}
\hline Scale & Generation & $N$ & Mean* & SD & $F$ & $P$ value & $\begin{array}{l}\text { Partial } \\
\text { Eta } \\
\text { Squared }\end{array}$ \\
\hline Exams/Papers & $\begin{array}{c}\text { Millennial } \\
\text { Gen X } \\
\text { Boomer }\end{array}$ & $\begin{array}{c}409 \\
129 \\
24\end{array}$ & $\begin{array}{l}3.739 \\
3.823 \\
3.759\end{array}$ & $\begin{array}{l}.396 \\
.414 \\
.415\end{array}$ & 2.709 & .068 & 011 \\
\hline Fabrication & $\begin{array}{c}\text { Millennial } \\
\text { Gen X } \\
\text { Boomer }\end{array}$ & $\begin{array}{c}409 \\
129 \\
24\end{array}$ & $\begin{array}{l}3.011 \\
3.353 \\
3.434\end{array}$ & $\begin{array}{l}.667 \\
.641 \\
.753\end{array}$ & 8.619 & $.000^{* *}$ & .033 \\
\hline Shortcuts & $\begin{array}{c}\text { Millennial } \\
\text { Gen X } \\
\text { Boomer }\end{array}$ & $\begin{array}{c}409 \\
129 \\
24\end{array}$ & $\begin{array}{l}2.333 \\
2.595 \\
2.688\end{array}$ & $\begin{array}{l}.711 \\
.671 \\
.763\end{array}$ & 5.749 & $.003^{\star *}$ & .022 \\
\hline Excuses & $\begin{array}{c}\text { Millennial } \\
\text { Gen X } \\
\text { Boomer }\end{array}$ & $\begin{array}{c}409 \\
129 \\
24 \\
\end{array}$ & $\begin{array}{l}2.866 \\
3.174 \\
3.193 \\
\end{array}$ & $\begin{array}{l}.746 \\
.697 \\
.844 \\
\end{array}$ & 7.096 & $.001^{* *}$ & .027 \\
\hline
\end{tabular}

Scheffe's post-hoc analyses were conducted to isolate significant differences $(p<.05)$ among generations. The means and standard deviations by generational groups are also displayed in Table 17. On the Fabrication scale, differences were observed between Millennials $(M=3.011)$ and Gen Xers $(M=3.353)$, and between Millennials $(M=3.011)$ and Baby Boomers $(M=3.434)$; the difference on Fabrication between Gen Xers $(M=3.353)$ and Baby Boomers $(M=3.434)$ was not significant. On Shortcuts, differences were significant between Millennials $(M=2.333)$ and Gen Xers $(M=2.595)$, but not between Millennials $(M=2.333)$ and Baby Boomers $(M=2.688)$ or between Gen Xers $(M=2.595)$, and Baby Boomers $(M=2.688)$. On Excuses, differences were significant between Millennials $(M=2.866)$ and Gen Xers $(M=3.174)$, but not between Millennials $(M=2.866)$ and Baby Boomers $(M=3.193)$, 
or between Gen Xers $(M=3.174)$, and Baby Boomers $(M=3.193)$.

Does the difference by generation in community college students' evaluation of academic activities as cheating vary with college experience? More than half of each generation reported having completed 30 or fewer college credits, $70 \%$ of Millennials, $59.6 \%$ of Gen Xers, and $53.6 \%$ of Baby Boomers. Because this resulted in relatively small cell sizes across four levels of college experience, it was decided to collapse the categories into two levels of college experience, $0-30$ credits and 31 and more credits; this recoded variable was the independent variable in the first MANOVA. With a Wilks' Lambda value of $.611(p=.769)$, the MANOVA revealed that the interaction between generation and college experience was not significant. There were no significant differences on any scale: Exams/Papers, $F(2,561)=.243, p=.784$; Fabrication, $F(2,561)=.927, p=.397$; Shortcuts, $F(2,561)=.267, p=.766$; and Excuses, $F(2,561)=.428, p=.652$.

Does the difference by gender in community college students' evaluation of academic activities as cheating vary by generation? Again, on the interaction between generation and gender in the first MANOVA, Wilks' Lambda was not significant, with a value $1.143(p=.331)$. There were no significant differences on any scale: Exams/Papers, $F(2,561)=.404, p=.668$; Fabrication, $F(2,561)=.058$, $p=.944 ;$ Shortcuts, $F(2,561)=.616, p=.541$; and Excuses, $F(2,561)=1.706, p=$ .183.

Do community college students differ by program of study in their evaluation of academic activities as cheating? As described above, because of the wide variety of programs represented and relatively low total number (60) in the program of study 
category "Other," this category was dropped from subsequent analyses (treated as missing data). Therefore, the first MANOVA was conducted with only three categories of program of study: Liberal Arts, Business, and Sci/Health.

The Wilks' Lambda value of 1.169 for the effect of program of study was not significant $(p=.286)$. There were no significant differences on any scale: Exams/Papers, $F(2,561)=.206, p=.935$; Fabrication, $F(2,561)=1.137, p=.338$; Shortcuts, $F(2,561)=.655, p=.623$; and Excuses, $F(2,561)=1.785, p=.131$.

Does the difference by generation in community college students' evaluation of academic activities as cheating vary with the extent to which their personal morality is grounded in a religious belief system? This research question was addressed by the second statistical model, in which the independent variables were generation and extent to which personal morality is grounded in a religious belief system, and the dependent variables were the four DoCS scale scores. The Wilks' Lambda value for this analysis was $.975(p=.911)$, and thus the relationship was not significant. There were no significant differences on any scale: Exams/Papers, $F(6,619)=1.078, p=$ .347 ; Fabrication, $F(6,619)=.274, p=.668$; Shortcuts, $F(6.619)=.323, p=.925$; and Excuses, $F(6,619)=.534, p=.783$.

\section{Summary}

Pilot study with the DoCS allowed for estimation of test-retest reliability, the enhancement of content validity, and the modification of the instrument based on factor analysis. The revised DoCS was completed by 650 respondents. Factor analysis was repeated, forcing the items into four scales based on the theoretical model of the instrument. Items that either did not strongly load on their respective factors 
$(\geq .30)$ or strongly loaded on more than one factor were deleted from the scales. The resulting scales were labeled Exams/Papers, Fabrication, Shortcuts, and Excuses.

The research questions were addressed with multivariate analyses of variance (MANOVAs), conducted separately for generation with the demographic characteristics (college experience, gender, and program of study) and for generation with the extent to which respondents rated their personal morality as grounded in a religious belief system. The results of these analyses are shown in Table 18. The main effect of generation on respondents' evaluation of academic activities as cheating was not significant on Exams/Papers, but was significant on Fabrication, Shortcuts, and Excuses. Millennials rated Fabrication items less strongly as cheating than did Gen Xers and Baby Boomers; Gen Xers and Baby Boomers did not differ in their ratings on the Fabrication scale. On the Shortcuts and Excuses scales, Millennials rated items less strongly as cheating that Gen Xers, but did not different significantly from Baby Boomers in their ratings on these scales. Program of study, and interactions between generation and demographic characteristics (college experience and gender) and with the impact of the extent to which respondents rated their personal morality as grounded in a religious belief system, were not significant. 
Table 18

Summary of Research Question Findings

\begin{tabular}{|c|c|c|}
\hline Question & \multicolumn{2}{|c|}{ Findings* } \\
\hline \multirow{7}{*}{$\begin{array}{l}\text { 1. Do community college students differ by } \\
\text { generation in their evaluation of academic } \\
\text { activities as cheating? }\end{array}$} & Exams/Papers & No difference \\
\hline & Fabrication & $\begin{array}{l}\text { Millennials rate } \\
\text { lower than Gen X } \\
\text { and Boomers }\end{array}$ \\
\hline & & $\begin{array}{l}\text { No difference } \\
\text { Gen } X \text { to } \\
\text { Boomers }\end{array}$ \\
\hline & Shortcuts & $\begin{array}{l}\text { Millennials rate } \\
\text { lower than Gen X }\end{array}$ \\
\hline & & $\begin{array}{l}\text { No difference } \\
\text { Millennial to } \\
\text { Boomers }\end{array}$ \\
\hline & Excuses & $\begin{array}{l}\text { Millennials rate } \\
\text { lower than Gen } X\end{array}$ \\
\hline & & $\begin{array}{l}\text { No difference } \\
\text { Millennial to } \\
\text { Boomers }\end{array}$ \\
\hline $\begin{array}{l}\text { 2. Does the difference among community } \\
\text { college students in their evaluation of academic } \\
\text { activities as cheating vary with college } \\
\text { experience? }\end{array}$ & & No difference \\
\hline $\begin{array}{l}\text { 3. Do the gender differences among } \\
\text { community college students in their evaluation } \\
\text { of academic activities as cheating vary with } \\
\text { generation? }\end{array}$ & & No difference \\
\hline $\begin{array}{l}\text { 4. Do community college students differ by } \\
\text { program of study in their evaluation of } \\
\text { academic activities as cheating? }\end{array}$ & & No difference \\
\hline $\begin{array}{l}\text { 5. Does the difference among community } \\
\text { college students in their evaluation of academic } \\
\text { activities as cheating vary with the extent to } \\
\text { which their personal morality is grounded in a } \\
\text { religious belief system? }\end{array}$ & & No difference \\
\hline
\end{tabular}

* lower ratings indicate less endorsement of activities as cheating 


\section{CHAPTER V}

\section{Discussion}

This section will first review the purpose and significance of this study. Then, the results will be discussed in detail, focusing first on the effect of generational membership, then on the effect of demographic characteristics, and finally on the effect of personal morality being grounded in a religious belief system. Limitations to the generalizability of the findings will be described. Finally, directions for future research and implications for practice suggested by the study findings will be discussed.

\section{Purpose and Significance}

The purpose of this study was to determine whether community college students varied by generation in their evaluation of academic activities as cheating, and to further determine whether such variation interacted with demographic variables and the extent to which personal morality is grounded in a religious belief system. Leaders in higher education have recognized for some time the complex interplay between academic dishonesty and student body diversity: "[a]cademic administrators, faculty, and students involved in trying to enhance the academic integrity climate need to acknowledge the diversity of attitude and behaviors surrounding issues of academic integrity as they plan for the future." (Hendershot, Drinan, \& Cross, 1999). With community colleges generally serving students of even greater diversity than many four-year institutions, the challenge and importance of understanding the diversity of community college students' attitudes is all the more critical, but as in many areas of 
research in higher education, the community college setting has been an "empirical black hole" (Pascarella \& Terenzini, 1998), with few reports in the literature.

Besides its relevance in the values development role of community colleges, academic integrity is additionally important as community colleges advance their place in higher education and increasingly compete for both public and private funds. Calls for accountability (Acker, 2007), demands for demonstration of graduate competency achievement, and fears for the future prestige of academic credentials (Genova, 2007) accompany news reports of plagiarized theses (Wasley, 2006), electronically assisted cheating (Epstein, 2005), and alteration of academic transcripts (La, 2005). Academic leaders have written about the special need for intervention against growing dishonesty in academic disciplines ranging from business (McCabe, 2005 ) to nursing (Tanner, 2004), and student services personnel have noted that, "[a]s society places greater emphasis on achievement and success, college cheating has reached epidemic proportions." (Angell, 2006, \ 1)

Reports on the prevalence of academic cheating in college have been drawn primarily from students' self reports. Whitley's 1998 meta-analysis of 107 studies dating back to 1970 determined an overall prevalence rate of $70.4 \%$ (individual reports ranging from $9 \%$ to $95 \%$ ). Analyzed by type of cheating, the lowest rate was on examinations (mean $43.1 \%$, range $4 \%$ to $82 \%$ ), and the highest rate was for plagiarism (mean 47.0\%, range 3\% to 98\%) (Whitley). Although McCabe and Bowers (1994) reported similar rates of cheating in studies conducted in 1963 and 1991, Whitley (1998) identified a curvilinear relationship over time in cheating on examinations; having dropped from $44.9 \%$ in $1969-1975$, to $24.8 \%$ in $1976-1980$ and $32.2 \%$ in $1981-$ 
1985 , exam cheating rose again to $46.4 \%$ in $1986-1990$ and $46.9 \%$ in $1991-1995$.

This, according to Whitley, was consistent with professors' then-current intuitions that cheating had been on the increase.

More recent reports support concern that academic cheating in college has not abated. At a highly selective four-year liberal arts college, $88 \%$ of students reported some type of cheating activity while in college; $53 \%$ reported cheating on exams, $42 \%$ on papers, and $70 \%$ on homework or laboratory assignments (Rettinger et al., 2004). Rather similar finding were reported from a southwestern university, with $85 \%$ of students reporting at least one episode of cheating while in college, $35 \%$ copying on a test and 74\% copying homework (Vowell \& Chen, 2004).

A number of studies have examined the evaluation of various academic activities as cheating, often to compare such evaluations among students with those of faculty (Barnett \& Dalton, 1981; Graham et al., 1994) or in conjunction with questions regarding students' personal engagement or knowledge of others' engagement in the activities (Carpenter et al., 2002). A few qualitative studies have sought to understand how students determine what is, and is not, cheating (Ashworth, Bannister, \& Thorne, 1997; Del Carlo, 2004; McCabe, Trevino, \& Butterfield, 1999; Saddlemire, 2005).

\section{Effect of Generational Membership}

The works of Howe and Strauss (2000, 2003; Strauss \& Howe, 1991, 1997) have contributed to the examination of differences in the attitudes and values among the different generations of today's students in a variety of settings, from the classroom (Gayeski, 2007; McCabe, \& Pavela, 2004; Tucker, 2006), to library use (Carlson, 2005; Holliday \& Li, 2004; Kasting, 2006), to workplace training (Alch, 
2000; Allerton, 2001). The effect of generational membership on students' evaluation of academic activities as cheating has not, however, been previously explored.

The findings of this study support the application of the works of Howe and Straus (2000, 2003; Strauss \& Howe, 1991, 1997) to the understanding of students' attitudes towards cheating. The Millennials have been identified as conventional and rule-followers (2003), and in what may be considered the more traditional, clearly established boundaries for high-stakes academic assessment activities, examinations and papers, students in this study did not vary significantly by generation in their evaluation of academic activities as cheating. Faculty and academic administrators may find it reassuring that, on average, students continue to evaluate academic activities that cross the line of integrity related to these traditional academic endeavors as cheating.

In other types of academic activities, however, generational differences did appear. Millennial generation students were significantly less likely than Gen Xers or Baby Boomers to evaluate academic activities on the Fabrication scale as cheating. On Shortcuts and Excuses, Millennials rated activities significantly less as cheating than Gen Xers. Although Millennials' ratings on Shortcuts and Excuses were not significantly differently than Baby Boomers, the mean differences did fall in the predicted directions, and the lack of significance differences may have been impacted by the small number of Baby Boomers in the study sample.

Additionally, on the Shortcuts scale, overall averages among each generational group fell below the level of agreeing that the activities were cheating. The same occurred among Millennials only on the Excuses scale, with the scale average falling 
on the side of disagreeing that the activities represented cheating; among Gen Xers and Baby Boomers, the scale average on Excuses fell on the side of considering the activities as cheating, but just barely.

These findings may relate to the core traits of Millennials labeled by Howe and Strauss (2003) as team-oriented, pressured, and achieving. Growing up with collaborative learning and team sports, Millennials, as a whole, are far more tightly connected with their friends and committed to the success of their groups than the more individualistic Gen Xers and Baby Boomers. They are also experiencing academic pressure unlike that experienced at the same age by their elders, fueled in part by their own push for continued high achievement. Taken together, these traits may logically extend to behaviors such as creating data for a homework assignment (Fabrication), watching a movie of a famous book instead of reading it as assigned (Shortcuts), or delaying turning in a paper with a falsified excuse (Excuses). It may be that the perceived necessity by Millennials to engage in these activities makes it less likely that they would consider them to be cheating.

\section{Effect of Demographic Characteristics}

Contrary to the prediction of this study, the generational differences among community college students in their evaluation of academic activities as cheating did not vary with their level of college experience. The conclusions of Rest (1994), Whitley (1998) and others (Ercegovac \& Richardson, 2004; Gaberson, 1997) have suggested that higher levels of college experience, linked to higher levels of moral development, are related to lower levels of cheating, and therefore were predicted to reduce variation among generations in their evaluations of academic activities as 
cheating. The hypothesis that Millennial generation students with higher levels of college experience, compared to Millennials with lower levels of college experience, would differ less from students of Generation $\mathrm{X}$ and Baby Boomers in their evaluation of academic activities as cheating was not supported. The lack of interaction between generational membership and college experience could have several explanations. It is possible that generational shifts in attitudes about cheating have influenced students at all levels of moral development in a fairly equal manner. It is also possible that, given that two-thirds of respondents in this study had completed 30 or fewer college credits, the impact of college experience on level of moral development was too small to be detected with significance with so small a sample of Baby Boomers. Whitley's (1998) meta-analysis found cheaters to have a lower level of moral development than non-cheaters, but at a small effect size.

Consistent with recent research findings, which have determined the historical male dominance in cheating to have faded, gender did not significantly interact with generation in students' evaluation of academic activities as cheating in this study. Crown and Spiller (1998) reported in their meta-analysis that, although studies conducted before 1972 concluded men cheated more than women, this relationship had become more tenuous over the next 20 years, becoming predominantly a nonsignificant relationship in the past 10 years. Crown and Spiller suggested that this trend might reflect a convergence of role requirements among men and women in collegiate settings. The findings of this study support the prediction that gender differences in students' evaluation of academic activities as cheating would not vary 
by generation, suggesting that any attitudinal differences between men and women towards cheating have diminished.

Program of study also was not significant in determining how students in this study evaluated academic activities as cheating. Previous studies have reported higher rates of cheating among business majors than students majoring in other disciplines (McCabe \& Trevino, 1995), including one study in a two-year college setting (Smyth \& Davis, 2003). Business education leaders have acknowledged that the nature of the curriculum and graduate competency goals, as well as an environment of often fierce competition for prestigious graduate school seats, may support a climate more prone to cheating than in other programs of study (Young, 2007). Roberts (1997) narrowed this question to determine that the greatest amount of unauthorized collaboration was reported by business students; performing and visual arts students report the lowest incidence of unauthorized collaboration, but the greatest incidence of making up excuses to avoid handing in a term paper or taking a test. In this study, however, program of study was not significant in determining how students evaluated academic activities as cheating. Again, a possible explanation for this finding could be the restriction in range among respondents in their college experience, with two-thirds having completed 30 or fewer college credits, and with many of these credits probably in general education courses not specific to their program of study, the extent to which these students had become socialized to their disciplines of study may have been minimal. 
Effect of Personal Morality Grounded in a Religious Belief System

For respondents in this study, the extent to which they rated their personal morality as grounded in a religious belief system did not significantly interact with generational membership in their evaluation of academic activities as cheating on any of the DoCS scales. Sutton and Hubs' (1995) found that students who reported higher levels of religious involvement were more likely to rate certain behaviors as cheating, including "working together with several students on a homework assignment when the instructor does not allow it," and that students with the highest level of religious involvement were more likely than those in the lowest group to agree that "cheating is never justified under any circumstances." Sutton and Hubs methodology, however, analyzed differences in students' evaluations of individual activity descriptions only, as opposed to the cluster of activities, scale score approach used in this study with the DoCS. The lack of interaction between generational membership and the extent to which students rated their personal morality as grounded in a religious belief system could have several explanations. It is possible that either generational shifts in attitudes about cheating have influenced students at all levels of religious involvement, or that high levels of religious involvement override generational differences.

Instrument Development

Although instrument development was not the primary goal of this study, the DoCS has been established as a valid and reliable instrument for the assessment of students' evaluations of academic activities as cheating. From its foundation in the literature, through its review by experts in higher education, pilot testing, revision, and 
factor analysis, the DoCS stands as a unique contribution to the future study of academic dishonesty.

Almost every analysis of cheating reviewed for this study utilized a different instrument; the exceptions to this have been largely in the work of McCabe with various colleagues, in some cases specifically seeking to make comparisons with earlier findings (McCabe \& Bowers, 1994; McCabe \& Pavela, 2004; McCabe \& Trevino, 1995, 1997; McCabe, Trevino, \& Butterfield, 1999; 2001). Other than McCabe, researchers have generally formulated individual lists of academic activities, as shown in Appendix A. Furthermore, the vast majority of researchers have conducted their analyses using individual cheating behaviors as their dependent variables, rather than assembling scales for different types of academic dishonesty, as has been accomplished with the DoCS. The lack of definitive measurements in the study of academic dishonesty has made generalization of findings, and theorybuilding, awkward at best.

Initial estimates of the reliability and validity of this instrument for the assessment of evaluations of academic activities as cheating were promising. The DoCS could be used in further research or program evaluation which could examine, for example, the effectiveness of treatments thought to improve college climates of academic integrity (such as honor codes) to measure attitude changes pre- and postintervention. It could also be used to update understandings of differences in definitions of cheating among subgroups in higher education, such as between students and faculty, or students in varying disciplines, or among Millennials and the yet-to-be-named next generation that will enter higher education. 


\section{Limitations}

Subject effects - social desirability. Although the design of this study purposefully did not pose questions about students' actual engagement in activities that might be considered academic cheating, in order to minimize the threat of social desirability, there is still a risk that students' desire to present themselves as appropriate or proper college students may have impacted their responses. If respondents believed that an appropriate college student would evaluate the activities described more strongly as cheating, then the findings may be positively skewed, with students having rated activities more strongly as cheating than they truly believed. On the other hand, if respondents had engaged in any of the activities being rated, then the more socially desirable position might be to rate the activity as not cheating, leading to negatively skewed results.

Sample size. The mean size of classes selected for inclusion in the study sample was 10.9 , rather than the expected 20 , resulting in a smaller overall sample than planned (650 versus 1000). Coupled with the continued drop in the enrollment of Baby Boomers over time, this resulted in the number of Baby Boomers for the entire analysis being only 30 , as opposed to the planned 100 . With no fewer than 100 subjects in each generational cohort, the one-way analysis of variance would have allowed, at the .05 level of significance, .32 power for a small effect size $\left(R^{2}=.01\right) ; .98$ power for a medium $\left(R^{2}=.06\right)$ effect size, and nearly 1.0 for a large effect size $\left(R^{2}=.14\right)$ (Aron \& Aron, 2003, p. 435). However, with only 30 subjects in the Baby Boomer group, these power values dropped, at the .05 level of significance, to .12 for a small effect size, .55 for a medium effect size, and .93 for a large effect size (Aron \& 
Aron, 2003, p. 435). With this reduction in power, there is nearly a $50 \%$ chance that a significant result of medium effect size was not detected. The small number of Baby Boomers may make generalizations from the results of this study more problematic.

Similar sample size limitations may have impacted the study findings regarding gender and program of study. Although the sample proportion of men versus women closely mirrored that of the U.S, community college population, it is possible that a larger sample of men may have revealed relationships not found in this study. In the same manner, the absence of substantial enrollments in engineering programs among the study participants did not allow for any conclusions regarding such programs.

Sample characteristics. Besides the mere size of the sample, other indeterminate characteristics of the sample may have biased the sample due to the timing of the data collection, creating an additional threat to external validity. Because data collection was accomplished mid-way through the semester rather than at the beginning of the semester, some students' attitudes and /or understandings about cheating may have been influenced by the course in which they were enrolled the time of the survey. While the risk of these influences was constant across all study participants, this effect may limit the generalizability of the study findings especially to students who are new to college enrollment. Additionally, students who were no longer attending class at the time of data collection (dropped, withdrawn, or simply stopped attending) may have held significantly different attitudes about cheating than those who persisted to mid-semester, and their absence from the sample may have skewed the results. 
Selection bias. Although class sections were selected randomly according to the sampling matrix for invitation to participate in the survey, instructor permission was required to access classes, and a few declined to participate. Additionally, sampling was limited to traditional class sections (omitting online courses) at a single campus of a single community college. Thus, results may not be generalizable to students in other communities, where local school systems may instill values differently during secondary education, or to other instructional formats, which may attract students with different attitudes or values.

With respect to the findings regarding program of study, it should also be noted that, especially when intended for transfer to four-year institutions, students in different programs of study at the community college level often have very few differences in their required courses of study. Thus, it may be that sufficient enculturation to the program of study has not occurred in this limited exposure, and significant interactions with generation might exist at the baccalaureate or graduate level.

\section{Future Research and Practice}

Several different lines of future research are suggested by the results of this study. In order to capture an assessment of students' evaluation of academic activities as cheating with minimal social desirability bias, participants in this study were not asked to report on their personal history of cheating behaviors. The understanding of generational differences among students with respect to academic integrity begun with this study would be further enhanced by extending research to both self-reported and objectively measured actual cheating behaviors. Obviously, the trade-off between 
validity of findings and ethical concerns becomes more tenuous when students are observed cheating, particularly in contrived situations. This line of inquiry could be extended to examine the impact of faculty of different generations on both the evaluation and the practice of academic cheating by their students.

A variety of student and instructional characteristics that were not examined in this study merit investigation. Because this study expressly excluded students enrolled in online courses, further research is needed to determine how students involved in online instruction may vary from traditional students, as well as by generation, in their evaluation of academic activities as cheating. Similarly, generational differences in attitudes and/or behaviors regarding academic cheating may vary between full-time and part-time students, between first-generation college students and those with family college experience, and those with higher versus lower grade point averages, all fertile ground for future study. On a larger scale, the effect of various community college characteristics also remains to be explored, such as relative size, rural versus suburban or urban setting, regional differences across the U.S., and the existence or vigor of a college's honor code.

The potential interaction of college experience with generational membership on students' evaluation of academic activities as cheating should be explored at the baccalaureate and graduate school levels, in order to determine whether this effect is observed at higher levels of college experience. Similarly, although this study did not find a significant interaction between generational membership and program of study in students' evaluation of academic activities as cheating, it is possible that sufficient socialization of these students to their academic and professional disciplines had not 
occurred for such differences to have developed to a measurable extent. Further research exploring how generational differences may vary among programs of study at the baccalaureate and graduate school levels could be of value to academic leaders in those disciplines as they seek to advance both the academic and professional integrity in their fields.

Research into the effectiveness of practices aimed at fostering a climate of academic integrity, from honor codes to specialized course requirements for documented cheaters, would be enhanced through the use of the DoCS instrument. With further work on the validity and reliability, the DoCS may serve to help standardize assessment of students' evaluation of academic activities as cheating, allowing for better informed study of the issue among administrators, faculty, counselors, and students. The DoCS could also be tested for validity in other populations, such as faculty and four-year institutions, and could then potentially be used to compare attitudes among various groups. For example, this approach would serve to extend Saddlemire's (2005) qualitative description of faculty perceptions of undergraduate academic dishonesty.

The findings of this study also support the general attitudes and values of the Millennial generation as described by Howe and Strauss (2000, 2003). In all aspects of educational research where characteristics such as team orientation and achievement pressure may be significant, replication among Millennial generation students is indicated. The sense is strong among educators that these students are significantly different from those of a decade and longer ago (Allerton, 2001; Carlson, 
2005; Godwin-Jones, 2005; Holliday \& Li, 2004; Kasting, 2006; McCabe \& Pavela, 2004; Tucker, 2006), but little has been researched in this regard.

Finally, the results of the factor analysis on the pilot study instrument revealed that the majority of students responding did not consider the technology used in cheating to be an issue in their evaluation of academic activities as cheating; what mattered to them, as evidenced by the pattern matrix analysis, was the purpose or intent of the cheating, not the device used, be it a paper cheat sheet or a personal digital assistant. This observation supports the description of many members of the Millennial generation as techno-natives, as opposed to Baby Boomers and many GenXers as techno-immigrants (Milliron, 2004).

Not surprisingly, the percentage of students from the Baby Boomers generation is shrinking, even on community college campuses; Table 19 shows the change in enrollments in the Virginia Community College system from fall of 2005 to fall of 2006.

Table 19

Generational Distribution of VCCS Students Fall, 2005 versus Fall, 2006

\begin{tabular}{lcc}
\hline \multicolumn{1}{c}{ Generation } & $\begin{array}{c}\text { Fall 2005 } \\
\text { Percent }\end{array}$ & $\begin{array}{c}\text { Fall 2006 } \\
\text { Percent }\end{array}$ \\
\hline Boomer & 10.8 & 10.3 \\
Generation X & 36.1 & 35.3 \\
Millennial & 53.1 & 54.4 \\
\hline
\end{tabular}

Note. Calculated excluding data reported of students under age 17, predominantly enrolled in high school based dual-enrollment classes 
But despite the disappearance of Baby Boomers from the ranks of community college students, they remain strongly represented among faculty and academic administrators, and although the faculty/administrator role has been shown to impact the evaluation of academic activities as cheating (Hard, Conway, \& Moran, 2006; Higbee \& Thomas, 2002; Pincus \& Schmelkin, 2003), the need for sensitivity to the generational influence in this area remains. The findings of this study clearly demonstrate that variation exists in the manner in which students of different generations evaluate academic activities as cheating. It is incumbent upon faculty and administrators in higher education to provide explicit descriptions of the boundaries of acceptable practices, especially where some practices may be acceptable in certain circumstances but not in others, such as working in groups on assigned projects versus unauthorized collaboration in other assignments. The findings of this study further demonstrate that earlier gender differences in attitudes towards cheating no longer hold. College personnel must be equally alert to potential cheating among women students as among men.

In practice, the results of this study support the recommendations of Dalton (1998) and McCabe (2005) regarding measures that should be taken by faculty, staff, and administrators to foster academic integrity on college campuses. Clearly, not all students share a common evaluation of academic activities as cheating, and this is complicated by differing instructional strategies from course to course; group work, for example, which may be required in a physics course may be inappropriate in a composition course. "A comprehensive instructional academic integrity policy should therefore include provisions for: (1) cheating definitions, rules, and sanctions, 
(2) moral education, and (3) management of environmental and situational factors." (Dalton, p. 9) Academic integrity, in order to flourish, must be discussed openly and its boundaries clearly delineated, in the context of the tools and resources available to students from videos of great books to the Internet.

The findings of this study provide a starting point for such dialog, first among community college administrators and faculty, and then among faculty, staff, and students. For some colleges, this dialog may lead to focused development of an honor code, towards which the Center for Academic Integrity can provide significant resources. For others, the orientation courses commonly offered for first-semester students may be enhanced with discussions about the meaning of academic integrity in specific situations. For still others, course syllabi which historically have not addressed academic dishonesty will begin to do so, with clear descriptions of behaviors allowed and prohibited in the completion of various assignments and assessments, along with detailed consequences which administrators can uphold. With each such step, the college climate of academic integrity will be enhanced, and the college community as a whole will be strengthened.

\section{Conclusions}

The promotion of academic integrity should be a sufficient reason, intrinsically, for community college leaders to want to understand how their students evaluate academic activities as cheating. However, public and political calls for stronger accountability in higher education are increasing the significance of the issue - every cheating scandal in the news calls into question the return on investment for funding poured into U.S. colleges and universities. The Secretary of Education's 
Commission on the Future of Higher Education began its work in September of 2005 with one of the five key forces under consideration being "demands for accountability," citing employers' questioning of the competencies of current college graduates and calls for new measures of quality in higher education (Miller \& Oldham, 2005). The community college leader who will be most effective in both mentoring a climate of academic integrity and in responding to accountability concerns will be the one who first understands the diversity of how community college students evaluate academic activities as cheating.

Leadership in any facet of the community college must be concerned about academic integrity - financial prosperity, sound buildings, or well-functioning technology services are of little significance if the fundamental values of higher education are not being achieved. As published by the National Association of Student Personnel Administrators: "Academic integrity is without question the cornerstone ethical standard in higher education. While educators may debate the role which colleges and universities play in the values education of students, there is little debate that academic integrity is the quintessential moral virtue of the academic community." (Dalton, 1998, p. 1) This study has demonstrated that, especially in the multi-generational student body of the community college, not all students share the same understandings, much less the understandings of their faculty, about what academic activities are appropriate in the context of academic integrity.

With community colleges serving as the provider of higher education for $45 \%$ of college undergraduate students nationwide (AACC, 2007), it is vital that community college leaders understand the diversity and changes in student 
perspectives about cheating With this understanding, they can, where necessary, change tactics in the building of culture and community in their institutions, to assure that the values development mission that community colleges historically share with all of higher education in the U.S. is fulfilled. 


\section{References}

Aaron, R. M. (1992). Student academic dishonesty: are collegiate institutions addressing the issues? NASPA Journal, 29(2), 107-113.

Acker, D. (2007, Winter). Shining the light on presidential accountability. The Presidency, 10 (1), 27-29.

Alch, M. L. (2000). Get ready for the Net generation. Training \& Development, 54. Retrieved October 8, 2005, from InfoTrac database.

Allerton, H. E. (2001, November). Generation why: They promise to be the biggest influence since the baby boomers. Training \&Development, 55(11). Retrieved May 21, 2007, from Academic OneFile database.

Alschuler, A. S., \& Blimling, G. S. (1995). Curbing epidemic cheating through systemic change. College Teaching, 43(4), 123-5.

American Association of Community Colleges (AACC). (2007, January). Community College Fact Sheet. Retrieved September 10, 2007 from www2.aacc.nche.edu/research/index/htm.

American Association of Community Colleges (AACC). (n.d.) Community Colleges Past to Present. Retrieved March 5, 2006 from www.aacc.nche.edu/Content/NavigationMenu/AboutCommunityColleges/ HistoricalInformation/PasttoPresent/Past_to_Present.htm.

Anderson, G. L. (1999). Cyberplagiarism: A look at the web term paper sites. College \& Research Libraries News, 60. Retrieved June 8, 2006, from Wilson Web database. 
Angell, L. R. (2006). The relationship of impulsiveness, personal efficacy, and academic motivation to college cheating. College Student Journal, 40. Retrieved July 25, 2006, from WilsonWeb database.

Aron, A., \& Aron, E. N. (2003). Statistics for psychology $\left(3^{r d}\right.$ ed.). Upper Saddle River, NJ: Prentice Hall.

Babbage, C. (1830). Reflections on the decline of science in England. New York: Augustus M. Kelley. (Reprinted, London: B. Fellowes.).

Bailey, P. A. (2001, March). Academic misconduct: responses from deans and nurse educators. Journal of Nursing Education, 40. Retrieved December 5, 2005, from WilsonWeb database.

Bernardi, R. A., Metzger, R. L., Bruno, R. G. S., Hoogkamp, M. A. W., Reyes, L. E., \& Barnaby, G. H. (2004). Examining the decision process of students' cheating behavior: An empirical study. Journal of Business Ethics, 50, $397-$ 414.

Bolin, A. U. (2004). Self-control, perceived opportunity, and attitudes as predictors of academic dishonesty. The Journal of Psychology, 138. Retrieved October 8, 2005, from InfoTrac database.

Brown, D. L. (2002). Cheating must be OK - everybody does it. Nurse Educator, $27(1), 6-8$.

Brown, L., Haviland, A., \& Morris, S. (1997, Spring). Generation X. Contemporary Education, 68. Retrieved November 3, 2005, from WilsonWeb database. 
Bunn, D. N., Caudill, S. B., \& Gropper, D. M. (1992). Crime in the classroom: an economic analysis of undergraduate student cheating behavior [Electronic version]. The Journal of Economic Education, 23(3), 197-207.

Burke, J. L. (1997). Faculty perceptions of and attitudes toward academic dishonesty at a two-year college. Unpublished doctoral dissertation, University of Georgia. Retrieved January 20, 2006 from ProQuest database.

Burling, S. (2001, November 24). Sept. 11 changed psyche of the U.S., but how deeply? Philadelphia Inquirer. Retrieved September 15, 2006, from www.lifecourse.com/media/clips/011124_pi.html.

Calabrese, R. L. \& Cochran, J. T. (1990). The relationship of alienation to cheating among a sample of American adolescents. Journal of Research and Development in Education, 23(2), 65-72.

Campbell, C. R., Swift, C. O., \& Denton, L. T. (2000). Cheating goes hitech: online term paper mills. Journal of Management Education, 24(6), 726744.

Campbell, H. E. (2006). Cheating, public administration education, and online courses: an essay and call to arms. Journal of Public Administration Education, 12(1), 33-47.

Carlson, S. (2005, October 7). The Net generation goes to college. The Chronicle of Higher Education. Retrieved December 26, 2005, from http://chronicle.com.free/v52/i07/07a03401.htm. 
Carpenter, D. D., Harding, T. S., Montgomery, S. M., \& Steneck, N. (2002).

P.A.C.E.S. - A study on academic integrity among engineering undergraduates (preliminary conclusions). Proceedings of the 2002 American Society for Engineering Education Annual Conference \& Exposition.

Cell phones (n.d.) Welcome to the world of child and teen modifications. Retrieved September 15, 2006, from http://myspace.quinnipiuc.edu/dczani/cell.htm.

Center for Academic Integrity (CAI). (1999, October). The Fundamental Values of Academic Integrity. Retrieved June 12, 2005, from http://www.academicintegrity.org.

Cizek, G. J. (1999). Cheating on tests: how to do it, detect it, and prevent it. Mahwah, NJ: Erlbaum.

Clough, W. (2002, January 18). A statement from President Wayne Clough on the recent academic honor code violations. Retrieved October 1, 2006, from www.gatech.edu/news-room/archive/news_releases/cheating.html.

Cochran, J. K., Chamlin, M. B., Wood, P. B., \& Sellers, C. S. (1999). Shame, embarrassment, and formal sanction threats: extending the deterrence/rational choice model to academic dishonesty. Sociological Inquiry, 69(1), 91-105.

Cohen, A. M., \& Brawer, F. B. (2003). The American Community College ( $4^{\text {th }}$ ed.). San Francisco: Jossey-Bass.

Cole, S., \& McCabe, D. L. (1996). Issues in academic integrity. New Directions for Student Services, 73, 67-77. 
Costello, A. B., \& Osborne, J. W. (2005). Best practices in exploratory factor analysis: Four recommendations for getting the most from your analysis. Practical Assessment, Research \& Evaluation, 10. Retrieved October 1, 2006, from http://pareonline.net/pdf/v10n7.pdf.

Coupland, D. (1991). Generation X. New York: St. Martin's Press.

Covey, S. R. (1999). The Seven Habits of Highly Effective People. New York: Simon and Schuster.

Crown, D. F., \& Spiller, M. S. (1998). Learning from the literature on collegiate cheating: a review of empirical research. Journal of Business Ethics, 17, 683700.

Dalton, J. C. (1998). Creating a campus climate for academic integrity. In D.D. Burnett, L. Rudolph, \& K.O. Clifford (Eds.), Academic integrity matters (pp. 1-11). Washington, D.C.: National Association of Student Personnel Administrators, Inc.

Davis, S. F., Grover, C. A., Becker, A.H., \& McGregor, L. N. (1992). Academic dishonesty: prevalence, determinants, techniques, and punishments. Teaching of Psychology, 19 (1), 16-20.

Davis, S. F., \& Ludvigson, H. W. (1995). Additional data on academic dishonesty and a proposal for remediation. Teaching of Psychology, 22, 119-21.

Dawkins, R. L. (2004). Attributes and statuses of college students associated with classroom cheating on a small-sized campus. College Student Journal, 38(1), 116-129. 
Del Carlo, D. I., \& Bodner, G. M. (2004). Students' perceptions of academic dishonesty in the chemistry classroom laboratory. Journal of Research in Science Teaching, 41(1), 47-64.

DePalma, M. T., Madey, S. F., \& Bornschein, S. (1995). Individual differences and cheating behavior: guilt and cheating in competitive situations. Personality and Individual Differences, 18(2), 761-769.

Diekhoff, G. M., LaBeff, E. E., Clark, R. E., Williams, L. E., Francis, B., \& Haines, V. J. (1996). College cheating: ten years later. Research in Higher Education, 37(4), 487-501.

Drake, C. A. (1941). Why students cheat. Journal of Higher Education, 12, 418420.

Ercegovac, Z., \& Richardson, J. V. (2004). Academic dishonesty, plagiarism included, in the digital age. College \& Research Libraries. Retrieved October, 6, 2005, from WilsonWeb database.

Fosdick, D. (2005, July 16). Older college students becoming more common. The Winchester Star, B-4.

Gaberson, K. B. (1997). Academic dishonesty among nursing students. Nursing Forum. Retrieved August 22, 2005, from InfoTrac database.

Gardner, W. M., \& Melvin, K. B. (1988). A scale for measuring attitude toward cheating. Bulleting of the Psychonomic Society, 26(5), 429-432.

Gayeski, D. M. (2007). What makes nexters tick? Implications for the design of college instruction. Educational Technology, 47(2), 35-38. 
Gehring, D., \& Pavela, G. (1994). Issues and perspectives on academic integrity $\left(2^{\text {nd }}\right.$ ed.). Washington, D.C.: National Association of Student Personnel Administrators.

Geiger, R. (1999). The ten generations of American higher education. In Altbach, P.G., Berdahl, R.O., \& Gumport, P. (Eds.), American higher education in the twenty-first Century (pp. 38-69). Baltimore, MD: The Johns Hopkins University Press.

Genova, J. (2007, January). Cheating in graduate school. The Greentree Gazette. $58,75$.

Godwin-Jones, R. (2005, January). Emerging technologies: messaging, gaming, peer-to-peer sharing: language learning strategies $\&$ tools for the millennial generation. Language, Learning \& Technology, 9(1). Retrieved May 21, 2007, from Academic OneFile database.

Gomes, L. (2006, January 18). Some students hire experts to do their school work. The Wall Street Journal, p. B1.

Graham, M. A., Monday, J., O'Brien, K., \& Steffen, S. (1994). Cheating at small colleges: an examination of student and faculty attitudes and behaviors. Journal of College Student Development, 35, 255-260.

Graphing calculator. (n.d.). Welcome to the world of child and teen modifications. Retrieved September 15, 2006, from http://myspace.quinnipiuc.edu/dczani/calc.htm. 
Grijalva, T. C., Nowell, C., \& Kerkvliet, J. (2006). Academic honesty and online courses. College Student Journal. Retrieved July 25, 2006, from WilsonWeb database.

Hard, S. F., Conway, J. M., \& Moran, A. C. (2006). Faculty and college student beliefs about the frequency of student academic misconduct. Journal of Higher Education, 77(6). Retrieved January 2, 2007 from WilsonWeb database.

Harding, T. S. (2001). On the frequency and causes of academic dishonesty among engineering students. Proceedings of the 2001 American Society for Engineering Education Annual Conference \& Exposition.

Harding, T. S., Carpenter, D. D., Montgomery, S. M., \& Steneck, N. H. (2002,). A comparison of the role of academic dishonesty policies of several colleges on the cheating behavior of engineering students and pre-engineering students. Proceedings of the $32^{\text {nd }}$ ASEE/IEEE Frontiers in Education Conference, Boston, MA.

Hendershott, A., Drinan, P. F., \& Cross, M. (1999). Gender and academic integrity. Journal of College Student Development, 40(4), 345-354.

Higbee, J. L., \& Thomas, P. (2002). Student and faculty perceptions of behaviors that constitute cheating. NASPA Journal (Online). Retrieved June 27, 2005, from WilsonWeb database.

Holliday, W., \& Li, Q. (2004). Understanding the millennials: updating our knowledge about students. Reference Services Review, 32(4), 356-66. 
Hollinger, R. C., \& Lanza-Kaduce, L. (1996). Academic dishonesty and the perceived effectiveness of countermeasures: an empirical survey of cheating a major public university. NASPA Journal, 33(4), 292-306.

Howe, N., \& Strauss, W. (2000). Millennials rising: the next great generation. New York: Vintage Books.

Howe, N., \& Strauss, W. (2003). Millennials go to college. Washington, D.C.: American Association of Collegiate Registrars and Admissions Officers.

Huss, M. T., Curnyn, J. P., Roberts, S. L., and Davis, S. F. (1993). Hard driven but not dishonest. Bulletin of the Psychonomic Society, 31, 429-430.

Hutton, P. A.. (2006). Understanding student cheating and what educators can do about it. College Teaching, 54. Retrieved July 25, 2006, from WilsonWeb database.

Johnston, D. K. (1996). Cheating: limits of individual integrity. Journal of Moral Education, 25(2), 159-71.

Jordan, A. E. (2001). College student cheating: the role of motivation, perceived norms, attitudes, and knowledge of institutional policy. Ethics and Behavior, $11(3), 233-247$.

Jordan, A. E. (2003). Implications of academic dishonesty for teaching in psychology. Teaching of Psychology, 30(3), 216-9.

Kasting, T. (2006, October 9). The 'Millennial' law student generation. New Jersey Law Journal. Retrieved May 21, 2007, from Academic OneFile database. 
Kelch, K. (2006, March 21). Baby boomers return to college to earn degrees. Lord Fairfax Community College Feature Release. Retrieved March 21, 2006, from www.Ifcc.edu/News/Releases/060321_release_babyboomer.html.

Kerkvliet, J., \& Sigmund, C. L. (1999). Can we control cheating in the classroom? The Journal of Economic Education. Retrieved December 5, 2005, from Wilson Web database.

King, P. M., \& Mayhew, M. J. (2002). Moral judgement development in higher education: insights from the defining issues test. Journal of Moral Education, $31(3), 247-270$.

Kleiner, C., \& Lord, M. (1999, November 22). The cheating game. U.S. News and World Report. Retrieved October 1, 2006, from

Kraus, J. (2002). Rethinking plagiarism: What our students are telling us when they cheat. Issues in Writing, 13. Retrieved December 5, 2005, from WilsonWeb database.

Kuh, G. (2001). College students today: Why we can't leave serendipity to chance. In Altbach, P. G., Gumport, P. J., \& Johnstone, D. B. (Eds.), In defense of American higher education (pp. 277-303). Baltimore, MD: Johns Hopkins University Press.

La, J. (2005, March 30). Altered grades lead to student's arrest. Daily Nexus Online. Retrieved September 15, 2006, from www.dailynexus.com/news/2005/9237.html. 
LaBeff, E. E., Clark, R. E., Haines, V. J., \& Diekhoff, G. M. (1990). Situational ethics and college student cheating. Sociological Inquiry, 60(2), 190-198.

Malesic, J. (2006, December 11). How dumb do they think we are? The Chronicle of Higher Education. Retrieved December 12, 2006, from http://chronicle.com/jobs/news/2006/12/2006121101c/careers.html.

Manolis, C., Levin, A., \& Dahlstrom, R. (1997). A generation X scale: creation and validation. Educational and Psychological Measurement, 57. Retrieved November 3, 2005, from WilsonWeb database.

Maramark, S., \& Maline, M. B. (1993). Academic dishonesty among college students. Issues in Education. (OR-93-3082). Washington, DC: Office of Educational Research, U.S. Department of Education.

McCabe, D. L. (2005, Summer/Fall). It takes a village: Academic dishonesty. Liberal Education, 91(3), 26-31.

McCabe, D. L., \& Bowers, W. J. (1994). Academic dishonesty among males in college: a thirty year perspective. Journal of College Student Development, $35,5-10$.

McCabe, D. L., \& Pavela, G. (2004). Ten (updated) principles of academic integrity. Change, 36(3), 10-15.

McCabe, D. L., \& Trevino, L. K. (1995). Cheating among business students: a Challenge for business leaders and educators. Journal of Management Education, 19(2), 205-218. 
McCabe, D. L., \& Trevino, L. K. (1997). Individual and contextual influences on academic dishonesty: a multicampus investigation. Research in Higher Education, 38 (3), 379-396.

McCabe, D. K., Trevino, L. K., \& Butterfield, K. D. (1999). Academic integrity in honor code and non-honor code environments: a qualitative investigation. Journal of Higher Education, 72. Retrieved June 27, 2005, from WilsonWeb database.

McCabe, D. L., Trevino, L. K., \& Butterfield, K. D. (2001). Dishonesty in academic environments: the influence of peer reporting requirements. Journal of Higher Education, 72. Retrieved June 27, 2005, from WilsonWeb database.

McMillan, J. H. (2004). Educational research: Fundamentals for the consumer (4 ${ }^{\text {th }}$ ed.). Boston: Pearson Education, Inc.

McNeel, S. P. (1994). College teaching and student moral development. In J. R. Rest \& D. Navarez (Eds.). Moral development in the professions (pp. 27-49). Hillsdale, NJ: Lawrence Erlbaum.

Merriam-Webster Online. (n.d.). Cheat. Retrieved September 3, 2006 from www.mw.com/dictionary/cheating.

Miller, C., \& Oldham, C. (2005). Issue Paper: Setting the Context [First in a series of issue papers to inform the work of the Secretary of Education's Commission on the Future of Higher Education]. Retrieved June 24, 2007, from http://www.ed.gov/about/bdscomm/list/hiedfuture/reports/miller-oldham.pdf. 
Miller, R. (2001, September). Projections for college attendance by younger and older students. National Panel Report: Briefing Papers. Retrieved March 12, 2006, from www.greaterexpectations.org/briefing_papers/Proj_forAttendance.html.

Milliron, M. D. (2004). The road to dotcalm in education. Journal of Asynchronous Learning Networks, 8(1). Retrieved June 27, 2007 from http://www.aln.org.publications/jaln/v8n1_milliron2.asp.

Moeck, P. G. (2002). Academic dishonesty: cheating among community college students. Community College Journal, 26, 479-491.

Miyazaki, I. (1963). China's examination hell. (Translated by C. Schirokaur, 1976). NY: Weatherhill.

MyExcusedAbsence.com. (n.d.) Retrieved September 16, 2006, from http//:www.myexcusedabsence.com

Nadelson, S. (2006, June). The role of the environment in student ethical behavior [Electronic version]. Journal of College \& Character, 7(5). Retrieved September 3, 2006, from http://www.collegevalues.org/pdfs/role\%20of\%20environment.pdf.

Nowell, C., \& Laufer, D. (1997). Undergraduate student cheating in the fields of business and economics. Journal of Economic Education, 28, 3-12.

Nuss, E. M. (1984). Academic integrity: comparing faculty and student attitudes. Improving College \& University Teaching, 32, 140-144.

Orcher, L. T. (2005). Conducting research: social and behavioral science methods. Glendale, CA: Pyrczak Publishing. 
Pactor, M. S., McKeen, W., \& Morris, J. (1990). Students' ethics require new ways to cope with cheating. Educator, 44(4), 57-59.

Pascarella, E. T. \& Terenzini, P. T. (1998). Studying college students in the $21^{\text {st }}$ century: meeting new challenges [Electronic version]. The Review of Higher Education, 2l(2), 151-165.

Paul, G. (Director). (2004, April 29). Caught cheating [Television series episode]. In C. Weinraub (Producer), Primetime live. New Hudson, MI: ABC News.

Petress, K. C. (2003). Academic dishonesty. Education, 123. Retrieved October 6, 2005, from WilsonWeb database.

Pincus, H. S., \& Schmelkin, L. P. (2003). Faculty perceptions of academic dishonesty: a multidimensional scaling analysis. The Journal of Higher Education, 74. Retrieved October 6, 2005, from WilsonWeb database.

Pino, N. W., \& Smith, W. L. (2003). College students and academic dishonesty. College Student Journal, 37 (4). Retrieved June 12, 2005, from WilsonWeb database.

Prescot, P. A. (1989). Academic misconduct: considerations for educational administrators. Journal of Professional Nursing, 5(5), 283-287.

Pulvers, K., \& Diekhoff, G. M. (1999). The relationship between academic dishonesty and college classroom environment. Research in Higher Education, 40 (4), 487-498.

Rest, J. R. (1994). Background: Theory and Research. In Rest, J. R. \& Narvaez, D. (Eds.) Moral Development in the Professions: Psychology and Applied Ethics. Hillsdale, N.J.: Lawrence Erlbaum Associates. 
Rest, J. R., Thoma, S. J., \& Edwards, L. (1997). Designing and validating a measure of moral judgment: stage preference and stage consistency approaches. Journal of Educational Psychology, 89(1), 5-28.

Rettinger, D. A., Jordan, A. E., \& Peschiera, F. (2004). Evaluating the motivation of other students to cheat: a vignette experiment. Research in Higher Education, $45(8), 873-890$.

Roberts, P., Anderson, J., \& Yanish, P. (1997, October). Academic misconduct: where do we start? Paper presented at the Annual Conference of the Northern Rocky Mountain Educational Research Association, Jackson, WY.

Robinson, E, Amburgey, R., \& Swank, E. (2004). Test cheating in a rural college: studying the importance of individual and situational factors. College Student Journal, 38. Retrieved June 12, 2005, from WilsonWeb database.

Roth, N. L., \& McCabe, D. L. (1995, November/December). Communication strategies for addressing academic dishonesty. Journal of College Student Development, 36(6), 531-541.

Saddlemire, M. T. (2005). Faculty perceptions of undergraduate academic dishonesty. Doctoral dissertation. Bowling Green University (UMI No. 3160371).

Savich, P. (2003). People versus corporations, the second reformation, and the age of wisdom. Retrieved September 17, 2006, from http://www.petersavich.com/Duck/Analysis/PVC/Fourth\%20Turning/ft.php?p $=9$. 
Slapinski, H. (1999). Y not love? American Demographics, 21(2), 62-66.

Smith, W. S. (2006). Employers and the new generation of employees. Community College Journal, 76(3), 8-13.

Smith, K. J., Davy, J. A., \& Easterling, D. (2004). An examination of cheating and its antecedents among marketing and management majors. Journal of Business Ethics, 50, 63-80.

Smyth, M. L., \& Davis, J.R. (2003). An examination of student cheating in the two-year college. Community College Review, 31 (1). Retrieved June 12, 2005, from WilsonWeb database.

Spiller, S., \& Crown, D. F. (1995). Changes over time in academic dishonesty at the collegiate level. Psychological Reports, 76, 763-768.

Sterngold, A. (2004). Confronting plagiarism: how conventional teaching invites cyber-cheating. Change, 36. Retrieved October 8, 2005, from InfoTrac database.

Storch, E.A., \& Storch, J. B. (2002). Fraternities, sororities, academic institutions: a decade of research. College Student Journal, 36(2), 247-252.

Strauss, W. \& Howe. N. (1991). Generations. New York: William Morrow and Co.

Strauss, W., \& Howe, N. (1997). The Fourth Turning: An American Prophecy. New York: Broadway Books.

Sutton, E. M., \& Hubs, M. E. (1995). Undergraduate student perceptions of academic dishonesty as a function of ethnicity and religious participation. NASPA Journal, 33(1), 19-34. 
Tang, S., \& Zuo, J. (1997). Profile of college examination cheaters. College Student Journal, 31(3), 340-346.

Thorpe, M. F., Pittenger, D. J., \& Reed, B. D. (1999). Cheating the researcher: a study of relation between personality measures and self-reported cheating. College Student Journal, 33 (1), 49-59.

Tibbitts, S. G. (1998). Differences between criminal justice majors and noncriminal justice majors in determinants of test cheating intentions. Journal of Criminal Justice Education, 9(1), 81-94.

Tucker, P. (2006, May-June). Teaching the millennial generation. The Futurist, 40(3). Retrieved May 21, 2007, from Academic OneFile database.

Univeristy of California. (2002). The manual of the Irvine division of the academic senate. Retrieved January 20, 2006, from www.senate.uci.edu/9_IrvineManual/3ASMAppendices/Appendix08.html.

U.Va. plagiarism scandal ends with 45 dismissals. (2002, November 26). CNN.com. Retrieved March 12, 2006, from http://archives.cnn.com/2002/EDUCATION/11/26/uva.plagiarism.ap.

Virginia Community College System. (2006a). VCCS fall semester 2005 enrollment by age. Retrieved August 28, 2006, from www.vccs.edu/vccsasr/Research/age05.htm.

Virginia Community College System. (2006b). VCCS fall semester 2005 enrollment by race. Retrieved October 1, 2006, from www.vccs.edu/vccsasr/Research/race05.htm. 
Virginia Community College Sysem. (2007). VCCS fall semester 2006 enrollment by age. Retrieved June, 24, 2007 from http://system.vccs.edu/vccsasr/Research/age06.htm.

Vowell, R. R., \& Chen, J. (2004). Predicting academic misconduct: a comparative test of four sociological explanations. Sociological Inquiry, $74(2), 226-249$.

Ward, D. A. (1987). Self-esteem and dishonest behavior revisited. Journal of Social Psychology, 126(2), 709-713.

Wasley, P. (2006, August 24). Ohio U. requires hearings for graduates accused of plagiarism who want to revise theses. The Chronicle of Higher Education. Retrieved September 3, 2006 from http://chronicle.com.daily/2006/08/200682405n.htm.

Wasley, P. (2007, March 29). Ohio U. revokes a degree for first time in investigation of plagiarism in engineering theses. The Chronicle of Higher Education. Retrieved May 21, 2007 from http://chronicle.com/daily/2007/03/2007032904n.htm.

West, T., Ravenscroft, S. P., \& Shrader, C. B. (2004). Cheating and moral judgment in the college classroom: a natural experiment. Journal of Business Ethics, 54, 173-183.

Whitley, B. E. (1998). Factors associated with cheating among college students: a review. Research in Higher Education, 39(3), 235-274. 
Whitley, B. E., Nelson, A. B., \& Jones, C. J. (1999). Gender differences in cheating attitudes and cheating behavior: a meta-analysis. Sex Roles: A Journal of Research, 41(9), 657- 680.

W\&M Undergraduate Honor Council. (2005). The honor code. Retrieved March 23, 2006, from www.wm.edu/so/honor-council/honorcode.htm.

Young, J. R. (2007, April 30). Cheating incident involving 34 students at Duke is Business school's biggest ever. The Chronicle of Higher Education.

Retrieved May 3, 2007, from

http://chronicle.com/daily/2007/04/2007043002n.htm.

Zaslow, J. (2004, July 1). Baby boomers not all alike. Sun News/Myrtlebeachhotline. Retrieved September 17, 2006, from http://www.freerepublic.com/focus/news/1169790/posts. 
APPENDICES 
Appendix A

Sources of Activities Included in Definitions of Cheating Scale Instrument

\begin{tabular}{|c|c|c|}
\hline Activity & $\begin{array}{l}\text { Number of } \\
\text { Sources } \\
\text { Using } \\
\text { Activity } \\
\text { (n=28) }\end{array}$ & Citations Using Activity* \\
\hline $\begin{array}{l}\text { Accessing a copy of an } \\
\text { exam/test/quiz prior to the } \\
\text { exam session }\end{array}$ & 11 & $2,3,6,9,11,12,14,15,16,18,25$ \\
\hline $\begin{array}{l}\text { Copying from another } \\
\text { student during an } \\
\text { exam/test/quiz }\end{array}$ & 21 & $\begin{array}{c}3,5,6,7,8,9,11,12,13,15,16,17,18,21,22,22,24,25 \\
27,28,29\end{array}$ \\
\hline $\begin{array}{l}\text { Asking another student } \\
\text { about questions on an } \\
\text { exam/test/quiz you have } \\
\text { not yet taken }\end{array}$ & 6 & $1,3,5,12,14,22$ \\
\hline $\begin{array}{l}\text { Delaying taking an } \\
\text { exam/test/quiz with a } \\
\text { falsified excuse }\end{array}$ & 8 & $5,6,15,16,20,23,25,26$ \\
\hline $\begin{array}{l}\text { Using unapproved notes } \\
\text { ("crib sheet") during an } \\
\text { exam/test/quiz }\end{array}$ & 18 & $1,3,5,8,9,11,12,15,16,17,18,21,22,24,25,26,27,28$ \\
\hline $\begin{array}{l}\text { Changing answers on a } \\
\text { graded exam/test/quiz and } \\
\text { reporting a grading error }\end{array}$ & 5 & $3,5,13,16.25$ \\
\hline $\begin{array}{l}\text { Submitting an assignment } \\
\text { you originally completed } \\
\text { for a previous class } \\
\text { ("recycling") }\end{array}$ & 1 & 5 \\
\hline $\begin{array}{l}\text { Claiming to have handed } \\
\text { in an assignment when } \\
\text { you did not }\end{array}$ & 1 & 5 \\
\hline $\begin{array}{l}\text { Working in groups on } \\
\text { homework/lab } \\
\text { reports/assignments }\end{array}$ & 12 & $1,3,4,5,12,13,14,16,17,22,23,26$ \\
\hline $\begin{array}{l}\text { Copying homework/lab } \\
\text { reports/assignments } \\
\text { written by another student }\end{array}$ & 19 & $\begin{array}{c}3,4,5,7,9,11,12,13,14,15,17,18,21,22,23,26,27,28 \\
29\end{array}$ \\
\hline
\end{tabular}

* Note: Numbers refer to literature sources as listed at end of table 


\begin{tabular}{|c|c|c|}
\hline Activity & $\begin{array}{l}\text { Number of } \\
\text { Sources } \\
\text { Using } \\
\text { Activity } \\
\text { (n=28) }\end{array}$ & Citations Using Activity \\
\hline $\begin{array}{l}\text { Changing or creating data } \\
\text { for homework/lab } \\
\text { reports/assignments }\end{array}$ & 6 & $1,14,16,21,22,23$ \\
\hline $\begin{array}{l}\text { Delaying turning in } \\
\text { homework/lab } \\
\text { reports/assignments with a } \\
\text { falsified excuse }\end{array}$ & 2 & 1,26 \\
\hline $\begin{array}{l}\text { Submitting a paper you } \\
\text { originally completed for a } \\
\text { previous class ("recycling") }\end{array}$ & 6 & $1,4,12,14,16,23$ \\
\hline $\begin{array}{l}\text { Copying from a book or } \\
\text { website without proper } \\
\text { citation }\end{array}$ & $15+1(s)$ & $1(s), 3,4,9,15,16,17,18,19,20,21,22,23,26,27,28$ \\
\hline $\begin{array}{l}\text { Turning in a paper } \\
\text { purchased from another } \\
\text { student or a commercial } \\
\text { firm }\end{array}$ & $15+1(s)$ & $1,4,5,7,9,11,12(s), 14,15,16,17,20,21,21,27,28$ \\
\hline $\begin{array}{l}\text { Delaying turning in a } \\
\text { paper with a falsified } \\
\text { excuse }\end{array}$ & 3 & $5,20,23$ \\
\hline $\begin{array}{l}\text { Adding fake or unused } \\
\text { references to a paper to } \\
\text { expand the bibliography }\end{array}$ & 12 & $1,4,5,6,16,17,19,20.21,22,23,27$ \\
\hline $\begin{array}{l}\text { Copying a paper written by } \\
\text { another student }\end{array}$ & 18 & $1,2,3,4,5,6,7,9,11,12,15,16,17,18,21,22,27,28$ \\
\hline $\begin{array}{l}\text { Permitting another student } \\
\text { to look at your answers } \\
\text { during an exam/test/quiz }\end{array}$ & 17 & $1,3,5,9,12,13,15,16,17,18,21,22,23,24,25,27,29$ \\
\hline $\begin{array}{l}\text { Taking an exam for } \\
\text { another student }\end{array}$ & 7 & $5,12,15,16,19,25,27$ \\
\hline $\begin{array}{l}\text { Providing completed } \\
\text { homework/lab } \\
\text { reports/assignments for } \\
\text { use by other students }\end{array}$ & 6 & $1,5,12,19,22,29$ \\
\hline
\end{tabular}

(s) denotes similar activity but not exact match 


\begin{tabular}{|c|c|c|}
\hline Activity & $\begin{array}{l}\text { Number of } \\
\text { Sources } \\
\text { Using } \\
\text { Activity } \\
\text { (n=28) } \\
\end{array}$ & Citations Using Activity \\
\hline $\begin{array}{l}\text { Providing papers for use } \\
\text { by other students }\end{array}$ & (in -2$)$ & $12,16,19$ \\
\hline $\begin{array}{l}\text { Completing homework/lab } \\
\text { reports/assignments for } \\
\text { pay }\end{array}$ & 1 & 19 \\
\hline Writing papers for pay & 1 & 19 \\
\hline $\begin{array}{l}\text { Text-messaging during an } \\
\text { exam to get answers }\end{array}$ & $2+2(s)$ & $12(\mathrm{~s}), 16,19,26(\mathrm{~s})$ \\
\hline $\begin{array}{l}\text { Storing answers to a test } \\
\text { in a calculator or Personal } \\
\text { Digital Assistant (PDA) }\end{array}$ & $3+1(s)$ & $5,13,19,27(s)$ \\
\hline $\begin{array}{l}\text { Copying assignment or } \\
\text { paper content from the } \\
\text { Internet }\end{array}$ & 4 & $8,10,19,22$ \\
\hline $\begin{array}{l}\text { Sending/storing cell phone } \\
\text { photos of exam/test/quiz } \\
\text { pages for others' use }\end{array}$ & 1 & 19 \\
\hline $\begin{array}{l}\text { Creating Internet } \\
\text { disruptions to gain another } \\
\text { attempt at an online } \\
\text { exam/test/quiz }\end{array}$ & 1 & 19 \\
\hline $\begin{array}{l}\text { Accessing instructor's or } \\
\text { college computer system } \\
\text { to alter grades }\end{array}$ & 1 & 19 \\
\hline
\end{tabular}

(s) denotes similar activity but not exact match

Sources

1. Angell, 2006.

2. Bernardi, et al., 2004.

3. Bolin, 2004.

4. Campbell, 2000.

5. Carpenter, et al., 2002. 
6. Cochran, et al., 1999.

7. Cole \& McCabe, 1996.

8. Dawkins, 2004.

9. Diekhoff, et al., 1996.

10. Ercegovac \& Richardson, 2004.

11. Gaberson, 1997.

12. Graham, et al., 1994.

13. Harding, et al., 2002.

14. Higbee \& Thomas, 2002.

15. Hollinger \& Lanza-Kaduce, 1996.

16. Maramark \& Maline, 1993.

17. McCabe \& Bowers, 1994.

18. McCabe \& Trevino, 1997.

19. Paul, 2004.

20. Pincus \& Schmelkin, 2003.

21. Pino \& Smith, 2003.

22. Rettinger, et al., 2004.

23. Roberts, et al., 1997.

24. Robinson, et al., 2004.

25. Smith, et al., 2004.

26. Storch \& Storch, 2002.

27. Sutton \& Hubs, 1995.

28. Thorpe, et al., 1999.

29. Vowell \& Chen, 2004. 
Appendix B

Sampling Matrix

\begin{tabular}{|c|c|c|c|c|}
\hline Day of Week ${ }^{*}$ & Time of Day & Developmental & Freshman & Sophomore \\
\hline \multirow{3}{*}{ Monday } & Morning & 2 & 2 & 2 \\
\hline & Afternoon & 2 & 2 & 2 \\
\hline & Evening & 1 & 2 & 1 \\
\hline & Morning & 2 & 2 & 2 \\
\hline \multirow[t]{3}{*}{ Tuesday } & Afternoon & 2 & 2 & 2 \\
\hline & Evening & 1 & 2 & 2 \\
\hline & Morning & 1 & 1 & 1 \\
\hline \multirow[t]{3}{*}{ Wednesday } & Afternoon & 1 & 1 & 1 \\
\hline & Evening & 1 & 2 & 1 \\
\hline & Morning & 1 & 1 & 1 \\
\hline \multirow[t]{3}{*}{ Thursday } & Afternoon & 1 & 1 & 1 \\
\hline & Evening & 1 & 1 & 1 \\
\hline & Morning & 1 & 1 & 1 \\
\hline \multirow{3}{*}{ Friday } & Afternoon & Not Applicable & 1 & 1 \\
\hline & Evening & Not Applicable & $\begin{array}{c}\text { Not } \\
\text { not }\end{array}$ & $\begin{array}{l}\text { Not } \\
\text { not }\end{array}$ \\
\hline & Morning & Not Applicable & 1 & 1 \\
\hline \multirow{2}{*}{ Saturday } & Afternoon & Not Applicable & 1 & $\begin{array}{c}\text { Not } \\
\text { Anplicable }\end{array}$ \\
\hline & Evening & Not Applicable & $\begin{array}{c}\text { Not } \\
\text { Applicable }\end{array}$ & $\begin{array}{c}\text { Not } \\
\text { Applicable }\end{array}$ \\
\hline
\end{tabular}

* Classes meeting more than once per week (e.g., Monday \& Wednesday) selected by first meeting day of the week. 
Appendix C

\section{Definitions of Cheating Scale - Original Version}

What is your age? [ ] $14-24$ [ ] 25-45 [ ] 46-63 [ ] 64 +years

What year were you born?

Gender?

[ ] Female

[ ] Male

Which of the following includes your program of college study?

[ ] Liberal Arts, General Studies, Creative Arts

[ ] Business, Administrative Support, Information Systems Technology

[ ] Science, Health Professions

[ ] Other: describe

Place an "X" in the box that best describes your evaluation that each of the following activities is cheating.

"Strongly Disagree" means that you do not consider the activity to be cheating, and "Strongly Agree" means that you do consider the activity to be cheating.

\begin{tabular}{|l|l|l|l|l|}
\hline \multicolumn{1}{|c|}{ Activity } & $\begin{array}{c}\text { Strongly } \\
\text { Disagree }\end{array}$ & Disagree & Agree & $\begin{array}{c}\text { Strongly } \\
\text { Agree }\end{array}$ \\
\hline $\begin{array}{l}\text { Accessing a copy of an exam/test/quiz } \\
\text { prior to the exam session }\end{array}$ & & & & \\
\hline $\begin{array}{l}\text { Copying from another student during an } \\
\text { exam/test/quiz }\end{array}$ & & & & \\
\hline $\begin{array}{l}\text { Asking another student about questions } \\
\text { on an exam/test/quiz you have not yet } \\
\text { taken }\end{array}$ & & & & \\
\hline $\begin{array}{l}\text { Delaying taking an exam/test/quiz with a } \\
\text { falsified excuse }\end{array}$ & & & & \\
\hline $\begin{array}{l}\text { Using unapproved notes ("crib sheet") } \\
\text { during an exam/test/quiz }\end{array}$ & & & & \\
\hline $\begin{array}{l}\text { Changing answers on a graded } \\
\text { exam/test/quiz and reporting a grading } \\
\text { error }\end{array}$ & & & & \\
\hline $\begin{array}{l}\text { Submitting an assignment you originally } \\
\text { completed for a previous class } \\
\text { ("recycling") }\end{array}$ & & & & \\
\hline $\begin{array}{l}\text { Claiming to have handed in an } \\
\text { assignment when you did not }\end{array}$ & & & & \\
\hline $\begin{array}{l}\text { Working in groups on homework/lab } \\
\text { reports/assignments }\end{array}$ & & & & \\
\hline $\begin{array}{l}\text { Copying homework/lab } \\
\text { reports/assignments written by another } \\
\text { student }\end{array}$ & & & & \\
\hline $\begin{array}{l}\text { Changing or creating data for } \\
\text { homework/lab reports/assignments }\end{array}$ & & & & \\
\hline $\begin{array}{l}\text { Delaying turning in homework/lab } \\
\text { reports/assignments with a falsified } \\
\text { excuse }\end{array}$ & & & & \\
\hline
\end{tabular}




\begin{tabular}{|l|l|l|l|l|}
\hline \multicolumn{1}{|c|}{ Activity } & \multicolumn{1}{|c|}{$\begin{array}{c}\text { Strongly } \\
\text { Disagree }\end{array}$} & Disagree & Agree & $\begin{array}{c}\text { Strongly } \\
\text { Agree }\end{array}$ \\
\hline $\begin{array}{l}\text { Submitting a paper you originally } \\
\text { completed for a previous class } \\
\text { ('recycling") }\end{array}$ & & & & \\
\hline $\begin{array}{l}\text { Copying from a book or website without } \\
\text { proper citation }\end{array}$ & & & & \\
\hline $\begin{array}{l}\text { Turning in a paper purchased from } \\
\text { another student or a commercial firm }\end{array}$ & & & & \\
\hline $\begin{array}{l}\text { Delaying turning in a paper with a } \\
\text { falsified excuse }\end{array}$ & & & & \\
\hline $\begin{array}{l}\text { Adding fake or unused references to a } \\
\text { paper to expand the bibliography }\end{array}$ & & & & \\
\hline $\begin{array}{l}\text { Copying a paper written by another } \\
\text { student }\end{array}$ & & & & \\
\hline $\begin{array}{l}\text { Permitting another student to look at } \\
\text { your answers during an exam/test/quiz }\end{array}$ & & & & \\
\hline Taking an exam for another student & & & & \\
\hline $\begin{array}{l}\text { Providing completed homework/lab } \\
\text { reports/assignments for use by other } \\
\text { students }\end{array}$ & & & & \\
\hline $\begin{array}{l}\text { Providing papers for use by other } \\
\text { students }\end{array}$ & & & & \\
\hline $\begin{array}{l}\text { Completing homework/lab } \\
\text { reports/assignments for pay }\end{array}$ & & & & \\
\hline Writing papers for pay & & & & \\
\hline $\begin{array}{l}\text { Text-messaging during an exam to get } \\
\text { answers }\end{array}$ & & & & \\
\hline $\begin{array}{l}\text { Storing answers to a test in a calculator } \\
\text { or Personal Digital Assistant (PDA) }\end{array}$ & & & & \\
\hline $\begin{array}{l}\text { Copying assignment or paper content } \\
\text { from the Internet }\end{array}$ & & & & \\
\hline $\begin{array}{l}\text { Sending/storing cell phone photos of } \\
\text { exam/test/quiz pages for others' use }\end{array}$ & & & & \\
\hline $\begin{array}{l}\text { Creating Internet disruptions to gain } \\
\text { another attempt at an online } \\
\text { exam/test/quiz }\end{array}$ & & & & \\
\hline $\begin{array}{l}\text { Accessing an instructor's or college } \\
\text { computer system to alter grades }\end{array}$ & & & & \\
\hline
\end{tabular}

Number of college credits you have completed, at this or any other college:

$$
\text { [ ] } 0-15 \quad \text { [ ] } 16-30 \quad \text { [ ] 31-45 [ ] } 46+
$$

My personal morality is grounded in a religious belief system:
[ ] Strongly Disagree
[ ] Disagree
[ ] Agree
[ ] Strongly Agree

Thank you for your participation. 


\section{Appendix D}

\section{Survey Instrument Feedback}

1. How easy was it to understand the purpose of the survey?

1

Very

Confusing
2

Slightly
Confusing
3

Not

Bad
4

Pretty Easy

to Understand
5

Very Easy to Understand

2. How easy was it to understand the directions on how you were supposed to answer the survey questions?

1

Very

Confusing
2

Slightly
Confusing
3

Not

$\mathrm{Bad}$
4

Pretty Easy

to Understand

\section{5}

Very Easy

to Understand

3. How easy was it to understand the actual questions in the survey?

1

Very

Confusing
2

Slightly
Confusing

3

Not

$\mathrm{Bad}$
4

Pretty Easy to Understand

\section{5}

Very Easy

to Understand

4. If any questions were very confusing, which ones? Feel free to mark up the survey form with suggestions for improvements.

5. How was the length of the survey?

$\begin{array}{ccc}1 & 2 & 3 \\ \text { Way } & \text { A Bit } & \text { Not } \\ \text { Too Long } & \text { Too Long } & \text { Bad }\end{array}$

Thank you again for your help in this important project! 


\section{Appendix E}

\section{Proctor Introduction of Survey to Class - Pilot Study}

Hello, my name is

Professor has graciously allowed us a few minutes of your class time

so that

you can participate in an important research study being conducted here at the College. By completing this survey, you will be contributing to a better understanding of community college students, who have not been included in most of the research about college students. You have been selected to participate in a pilot study, so you will be asked to complete this same survey again next week.

I will pass out a packet to each of you. In the packet, you will find a letter explaining the study, and your right to participate or not participate without penalty. Although you may decline to participate, we hope you will be willing to take just a few minutes to contribute to this important study. You will also find 2 separate surveys, and an envelope labeled Survey Number One. When you have completed the surveys, please seal them in the envelope and bring them to me. I will put your sealed envelope into a large envelope and ask you to put your initials on the outer envelope so that next week, we can match this survey with the one you complete then. When you completed the second survey next week, the two envelopes will be stapled together, and your identifying information will be destroyed. It is expected to take most students only about 10 minutes to complete the survey each time. 
If you have any questions about how to complete the survey, please raise your hand.

I am not allowed, however, to provide any explanations about the actual survey questions.

Professor has indicated that

[either] ... s/he will return to class at (time)

[or] ... you are free to leave for the day when you are finished with this survey. 


\section{Appendix F}

\section{Letter to Survey Participants - Pilot Study}

Dear Student,

I am a doctoral student in the Community College Leadership Program at Old Dominion University. As part of the requirements to complete my degree, I am conducting a study about what activities community college students consider to be cheating. This information will be used to help faculty, staff, and administrators at community colleges develop better ways to help students be successful in their studies. By completing this survey, you will be contributing to a better understanding of community college students, who have not been included in most of the research about college students. You are being asked to participate in a pilot study, which serves as a test of the survey instrument before it is used for a larger group of students.

You were selected to participate in this study because you are enrolled in a community college course that was chosen according to its meeting schedule and academic level to provide a sample of students representing all the student body. Completion of this survey will only take about 10 minutes. Although the survey does not ask for any information that will identify you as an individual, the proctor has explained the procedure that will be used to match your survey one week with your survey the following week. In the end, your responses will remain completely anonymous. The instructor of your class will not see any of the survey forms. Your instructor will only receive a summary of how all students sampled from the entire College responded, which is expected to be completed in the fall of 2007. 
If you would like a copy of the results of this study, please feel free to contact me at kwotr001@odu.edu and I will send them to you. Thank you for your help with this important project.

Kathleen E. Wotring 


\section{Appendix G}

Original DoCS Factor Analysis Pattern Matrix

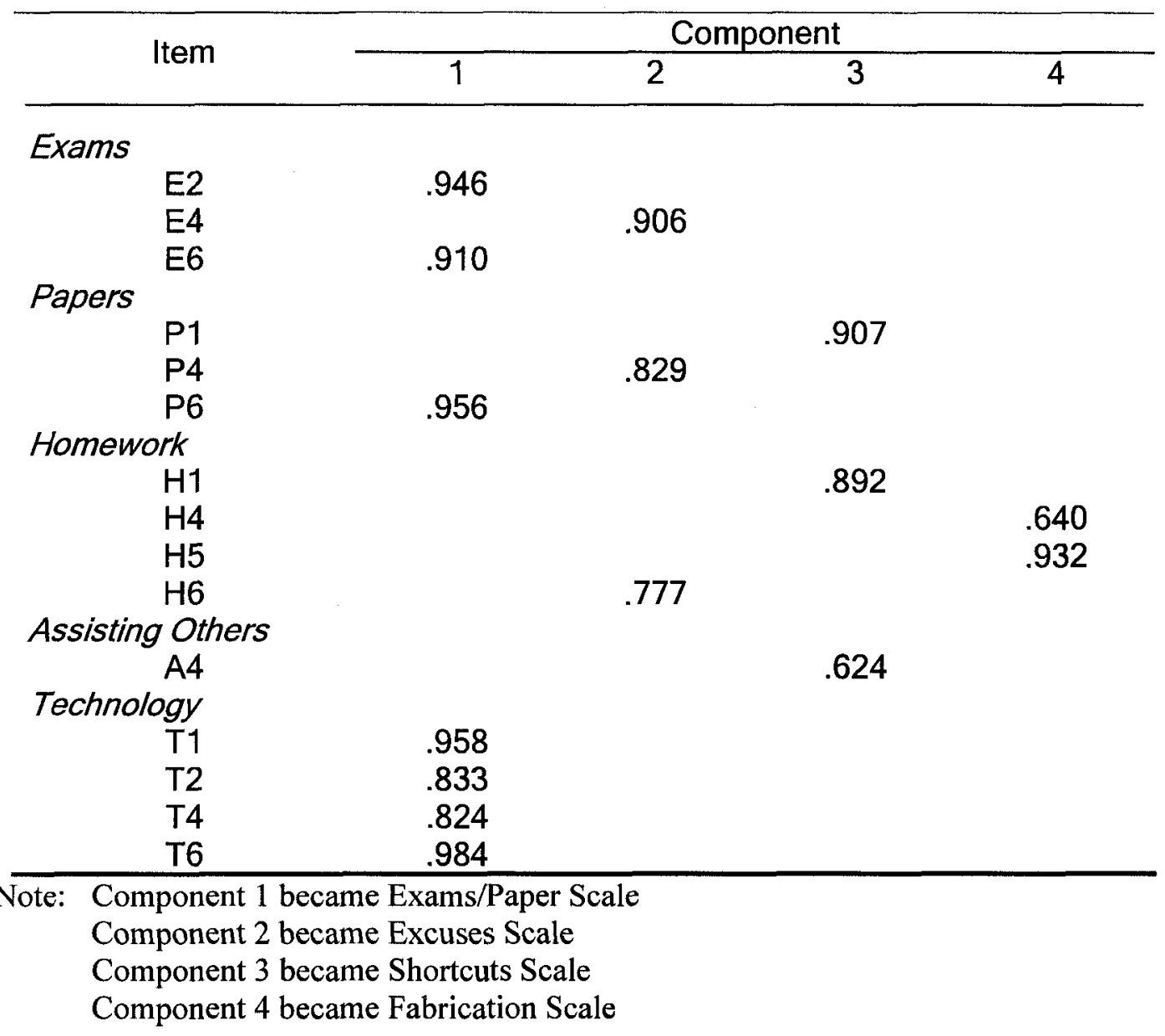




\section{Appendix $\mathbf{H}$}

\section{Definitions of Cheating Scale - Final Version}
What is your age?
[ ] $14-24$
[ ] $25-45$
[ ] $46-63$
[ ] 64 +years

What year were you born?

Gender?

[ ] Female [ ] Male

Which of the following includes your program of college study?

[ ] Liberal Arts, General Studies, Creative Arts

[ ] Business, Administrative Support, Information Systems Technology

[ ] Science, Health Professions

[ ] Other: describe

Place an " $\mathrm{X}$ " in the box that best describes your evaluation that each of the following activities is cheating.

"Strongly Disagree" means that you do not consider the activity to be cheating, and "Strongly Agree" means that you do consider the activity to be cheating.

\begin{tabular}{|c|c|c|c|c|}
\hline Activity & $\begin{array}{l}\text { Strongly } \\
\text { Disagree } \\
\text { (not cheating) }\end{array}$ & Disagree & $\begin{array}{l}\text { Agree } \\
\text { (is cheating) }\end{array}$ & $\begin{array}{l}\text { Strongly } \\
\text { Agree } \\
\text { (is cheating) }\end{array}$ \\
\hline $\begin{array}{l}\text { Changing answers on a graded } \\
\text { exam/test/quiz and reporting a grading } \\
\text { error }\end{array}$ & & & & \\
\hline $\begin{array}{l}\text { Copying from another student during an } \\
\text { exam/test/quiz }\end{array}$ & & & & \\
\hline $\begin{array}{l}\text { Text-messaging during an exam to get } \\
\text { answers }\end{array}$ & & & & \\
\hline $\begin{array}{l}\text { Storing answers to a test in a calculator or } \\
\text { Personal Digital Assistant (PDA) }\end{array}$ & & & & \\
\hline $\begin{array}{l}\text { Accessing an instructor's or college } \\
\text { computer system to alter grades }\end{array}$ & & & & \\
\hline $\begin{array}{l}\text { Copying a paper written by another } \\
\text { student }\end{array}$ & & & & \\
\hline $\begin{array}{l}\text { Sending/storing cell phone photos of } \\
\text { exam/test/quiz pages for others' use }\end{array}$ & & & & \\
\hline $\begin{array}{l}\text { Inventing false personal events to } \\
\text { complete an assigned report }\end{array}$ & & & & \\
\hline $\begin{array}{l}\text { Having someone else make a required } \\
\text { poster because his work is neater }\end{array}$ & & & & \\
\hline $\begin{array}{l}\text { Copying homework/lab } \\
\text { reports/assignments written by another } \\
\text { student }\end{array}$ & & & & \\
\hline $\begin{array}{l}\text { Changing or creating data for } \\
\text { homework/lab reports/assignments }\end{array}$ & & & & \\
\hline $\begin{array}{l}\text { Adding fake or unused references to a } \\
\text { paper to expand the bibliography }\end{array}$ & & & & \\
\hline $\begin{array}{l}\text { Recording activities not actually } \\
\text { completed for class assignments }\end{array}$ & & & & \\
\hline
\end{tabular}




\begin{tabular}{|l|l|l|l|l|}
\hline \multicolumn{1}{|c|}{ Activity } & $\begin{array}{c}\text { Strongly } \\
\text { Disagree } \\
\text { (not cheating) }\end{array}$ & Disagree & Agree & $\begin{array}{c}\text { Strongly } \\
\text { Agree } \\
\text { (not cheating) }\end{array}$ \\
(is cheating) & & & \\
\hline $\begin{array}{l}\text { Submitting a paper you originally } \\
\text { completed for a previous class } \\
\text { ("recycling") }\end{array}$ & & & & \\
\hline $\begin{array}{l}\text { Not contributing your fair share in a } \\
\text { group project }\end{array}$ & & & & \\
\hline $\begin{array}{l}\text { Watching a movie of a famous book } \\
\text { instead of reading it as assigned }\end{array}$ & & & & \\
\hline $\begin{array}{l}\text { Submitting an assignment you } \\
\text { originally completed for a previous } \\
\text { class ('recycling") }\end{array}$ & & & & \\
\hline $\begin{array}{l}\text { Reading published summaries or } \\
\text { study guides instead of an assigned } \\
\text { book }\end{array}$ & & & & \\
\hline $\begin{array}{l}\text { Borrowing a term paper from a friend } \\
\text { to use }\end{array}$ & & & & \\
\hline $\begin{array}{l}\text { Exaggerating personal problems to } \\
\text { take an Incomplete in a course }\end{array}$ & & & & \\
\hline $\begin{array}{l}\text { Delaying turning in a paper with a } \\
\text { falsified excuse }\end{array}$ & & & & \\
\hline $\begin{array}{l}\text { Making a false excuse not to meet } \\
\text { with your group to work on an } \\
\text { assigned project }\end{array}$ & & & & \\
\hline $\begin{array}{l}\text { Delaying taking an exam/test/quiz } \\
\text { with a falsified excuse }\end{array}$ & & & & \\
\hline $\begin{array}{l}\text { Delaying turning in homework/lab } \\
\text { reports/assignments with a falsified } \\
\text { excuse }\end{array}$ & & & & \\
\hline $\begin{array}{l}\text { Skipping class when your group } \\
\text { presentation is scheduled }\end{array}$ & & & & \\
\hline
\end{tabular}

Number of college credits you have completed, at this or any other college:
[ ] $0-15$
[ ] $16-30$
[ ] 39-45
[ ] $46+$

My personal morality is grounded in a religious belief system:
[ ] Strongly Disagree
[ ] Disagree
[ ] Agree
[ ] Strongly Agree

Thank you for your participation. 


\section{Appendix I}

\section{Proctor Introduction of Survey to Class}

Hello, my name is

Professor has graciously allowed us a few minutes of your class time

so that

you can participate in an important research study being conducted here at the College. By completing this survey, you will be contributing to a better understanding of community college students, who have not been included in most of the research about college students.

I will pass out a packet to each of you. In the packet, you will find a letter explaining the study, and your right to participate or not participate without penalty. Although you may decline to participate, we hope you will be willing to take just a few minutes to contribute to this important study.

You will also find a survey, a pencil, and an envelope. When you have completed the survey, please seal it in the envelope and bring it to me. It is expected to take most students only about 10 minutes to complete the survey.

If you have any questions about how to complete the survey, please raise your hand. I am not allowed, however, to provide any explanations about the actual survey questions.

Professor has indicated that

[either]

$\ldots \mathrm{s} /$ he will return to class at (time)

[or]... you are free to leave for the day when you are finished with this survey. 


\title{
Appendix $\mathbf{J}$
}

\section{Letter to Survey Participants}

\section{Dear Student,}

I am a doctoral student in the Community College Leadership Program at Old Dominion University. As part of the requirements to complete my degree, I am conducting a study about what activities community college students consider to be cheating. This information will be used to help faculty, staff, and administrators at community colleges develop better ways to help students be successful in their studies. By completing this survey, you will be contributing to a better understanding of community college students, who have not been included in most of the research about college students.

You were selected to participate in this study because you are enrolled in a community college course that was chosen according to its meeting schedule and academic level to provide a sample of students representing all of the student body. Completion of this survey will only take about 10 minutes. The survey does not ask for any information that will identify you as an individual, and your responses will remain completely anonymous. The instructor of your class will not see any of the survey forms. Your instructor will only receive a summary of how all students sampled from the entire College responded, which is expected to be completed in the fall of 2007.

If you would like a copy of the results of this study, please feel free to contact me at kwotr001@odu.edu and I will send them to you.

Thank you for your help with this very important project.

\author{
Kathleen E. Wotring
}


Appendix K

DoCS Instrument Factor Analysis Pattern Matrix

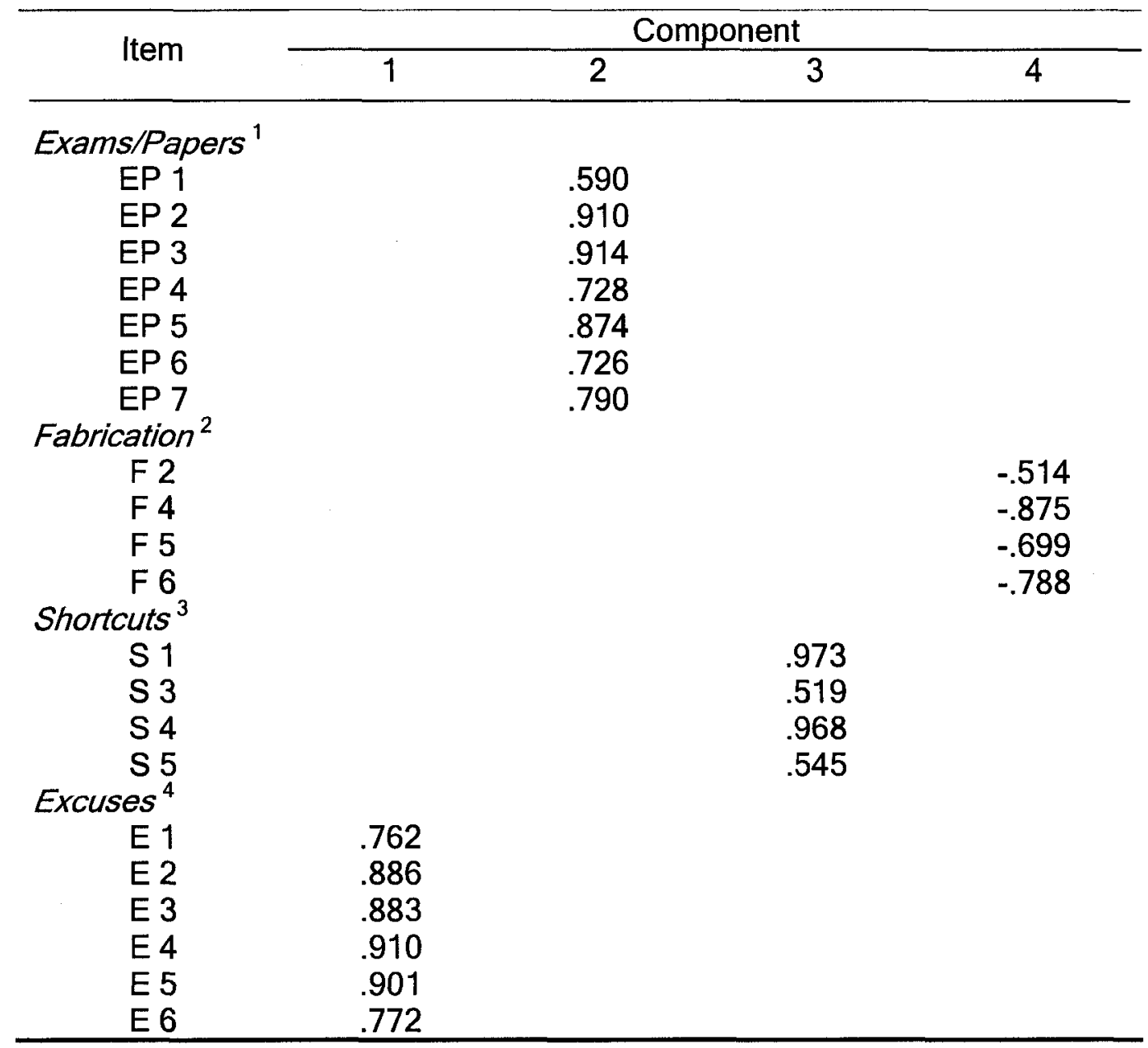

Eigenvalue $=2.859 ;$ Chronbach's alpha $=.899$

Eigenvalue $=.996 ;$ Chronbach's alpha $=.827$

Eigenvalue $=1.662 ;$ Chronbach's alpha $=.846$

Eigenvalue $=9.363 ;$ Chronbach's alpha $=.935$ 
Appendix L

Retained DoCS Item Descriptive Statistics

\begin{tabular}{|c|c|c|c|c|c|c|c|}
\hline \multirow{2}{*}{ Scale/Item* } & \multirow{2}{*}{$\mathbf{n}$} & \multirow{2}{*}{$M^{* *}$} & \multirow{2}{*}{$S D$} & \multicolumn{4}{|c|}{ Percentage by Response Category } \\
\hline & & & & $\begin{array}{l}\text { Strongly } \\
\text { Disagree }\end{array}$ & Disagree & Agree & $\begin{array}{c}\text { Strongly } \\
\text { Agree }\end{array}$ \\
\hline Exams/Papers & & & & & & & \\
\hline $\begin{array}{l}\text { EP1. Changing } \\
\text { answers on a } \\
\text { graded exam } \\
\text { /test/quiz and } \\
\text { reporting a grading } \\
\text { error }\end{array}$ & 644 & 3.71 & .647 & 2.8 & 2.3 & 15.5 & 79.3 \\
\hline $\begin{array}{l}\text { EP2. Copying from } \\
\text { another student } \\
\text { during an } \\
\text { exam/test/quiz }\end{array}$ & 650 & 3.82 & .442 & 0.6 & 0.5 & 15.4 & 83.5 \\
\hline $\begin{array}{l}\text { EP3. Text- } \\
\text { messaging during } \\
\text { an exam to get } \\
\text { answers }\end{array}$ & 650 & 3.8 & .469 & 0.8 & 0.8 & 15.8 & 82.6 \\
\hline $\begin{array}{l}\text { EP4. Storing } \\
\text { answers to a test } \\
\text { in a calculator or } \\
\text { Personal Digital } \\
\text { Assistant (PDA) }\end{array}$ & 650 & 3.68 & .550 & 0.6 & 2.5 & 24.8 & 72.2 \\
\hline $\begin{array}{l}\text { EP5. Accessing an } \\
\text { instructor's or } \\
\text { college computer } \\
\text { system to alter } \\
\text { grades }\end{array}$ & 650 & 3.85 & .398 & 0.5 & 0.5 & 11.8 & 87.2 \\
\hline $\begin{array}{l}\text { EP6. Copying a } \\
\text { paper written by } \\
\text { another student }\end{array}$ & 649 & 3.72 & .537 & 0.6 & 2.5 & 21.1 & 75.8 \\
\hline $\begin{array}{l}\text { EP7. Sending/ } \\
\text { storing cell phone } \\
\text { photos of } \\
\text { exam/test/quiz } \\
\text { pages for others' } \\
\text { use }\end{array}$ & 648 & 3.74 & .527 & 0.6 & 2.3 & 19.8 & 77.3 \\
\hline
\end{tabular}




\begin{tabular}{|c|c|c|c|c|c|c|c|}
\hline \multirow{2}{*}{ Scale/Item* } & \multirow{2}{*}{$n$} & \multirow{2}{*}{$M^{\star \star}$} & \multirow{2}{*}{ SD } & \multicolumn{4}{|c|}{ Percentage by Response Category } \\
\hline & & & & $\begin{array}{l}\text { Strongly } \\
\text { Disagree }\end{array}$ & Disagree & Agree & $\begin{array}{c}\text { Strongly } \\
\text { Agree }\end{array}$ \\
\hline \multicolumn{8}{|l|}{ Fabrication } \\
\hline $\begin{array}{l}\text { F2. Having someone } \\
\text { else make a required } \\
\text { poster because his } \\
\text { work is neater }\end{array}$ & 647 & 3.03 & .872 & 4.2 & 23.8 & 36.5 & 35.5 \\
\hline $\begin{array}{l}\text { F4. Changing or } \\
\text { creating data for } \\
\text { homework/lab reports/ } \\
\text { assignments }\end{array}$ & 641 & 3.05 & .845 & 2.5 & 25.9 & 36.0 & 35.6 \\
\hline $\begin{array}{l}\text { F5. Adding fake or } \\
\text { unused references to a } \\
\text { paper to expand the } \\
\text { bibliography }\end{array}$ & 647 & 3.25 & .793 & 2.0 & 15.9 & 36.9 & 45.1 \\
\hline $\begin{array}{l}\text { F6. Recording activities } \\
\text { not actually completed } \\
\text { for class assignments }\end{array}$ & 643 & 3.12 & .843 & 3.3 & 20.4 & 37.3 & 39.0 \\
\hline \multicolumn{8}{|l|}{ Shortcuts } \\
\hline $\begin{array}{l}\text { S1. Submitting a paper } \\
\text { you originally } \\
\text { completed for a } \\
\text { previous class } \\
\text { ("recycling") }\end{array}$ & 631 & 2.40 & .922 & 14.7 & 45.8 & 23.8 & 15.7 \\
\hline $\begin{array}{l}\text { S3. Watching a movie } \\
\text { of a famous book } \\
\text { instead of reading it as } \\
\text { assigned }\end{array}$ & 626 & 2.46 & .803 & 8.6 & 48.4 & 31.8 & 11.2 \\
\hline $\begin{array}{l}\text { S4. Submitting an } \\
\text { assignment you } \\
\text { originally completed for } \\
\text { a previous class } \\
\text { ("recycling") }\end{array}$ & 626 & 2.42 & .906 & 13.3 & 47.0 & 24.3 & 15.5 \\
\hline $\begin{array}{l}\text { S5. Reading published } \\
\text { summaries or study } \\
\text { guides instead of an } \\
\text { assigned book }\end{array}$ & 629 & 2.41 & .825 & 10.0 & 51.4 & 26.7 & 11.9 \\
\hline
\end{tabular}




\begin{tabular}{|c|c|c|c|c|c|c|c|}
\hline \multirow{2}{*}{ Scale/Item* } & \multirow{2}{*}{$\mathrm{n}$} & \multirow{2}{*}{$M^{* *}$} & \multirow{2}{*}{ SD } & \multicolumn{4}{|c|}{ Percentage by Response Category } \\
\hline & & & & $\begin{array}{l}\text { Strongly } \\
\text { Disagree }\end{array}$ & Disagree & Agree & $\begin{array}{c}\text { Strongly } \\
\text { Agree }\end{array}$ \\
\hline \multicolumn{8}{|l|}{ Excuses } \\
\hline $\begin{array}{l}\text { E1. } \\
\text { Exaggerating } \\
\text { personal } \\
\text { problems to take } \\
\text { an Incomplete in } \\
\text { a course }\end{array}$ & 628 & 2.98 & .868 & 4.5 & 25.2 & 36.1 & 32.3 \\
\hline $\begin{array}{l}\text { E2. Delaying } \\
\text { turning in a } \\
\text { paper with a } \\
\text { falsified excuse }\end{array}$ & 628 & 2.97 & .851 & 4.0 & 25.8 & 39.5 & 30.7 \\
\hline $\begin{array}{l}\text { E3. Making a } \\
\text { false excuse not } \\
\text { to meet with } \\
\text { your group to } \\
\text { work on an } \\
\text { assigned project }\end{array}$ & 630 & 2.87 & .866 & 3.7 & 33.7 & 34.4 & 28.3 \\
\hline $\begin{array}{l}\text { E4. Delaying } \\
\text { taking an } \\
\text { exam/test/quiz } \\
\text { with a falsified } \\
\text { excuse }\end{array}$ & 627 & 2.98 & .848 & 3.3 & 26.8 & 38.3 & 31.6 \\
\hline $\begin{array}{l}\text { E5. Delaying } \\
\text { turning in } \\
\text { homework/lab } \\
\text { reports/assignm } \\
\text { ents with a } \\
\text { falsified excuse }\end{array}$ & 629 & 2.94 & .834 & 3.2 & 28.5 & 39.7 & 28.6 \\
\hline $\begin{array}{l}\text { E6. Skipping } \\
\text { class when your } \\
\text { group } \\
\text { presentation is } \\
\text { scheduled }\end{array}$ & 629 & 3.05 & .893 & 3.2 & 27.8 & 29.6 & 39.4 \\
\hline
\end{tabular}


VITA

\section{Kathleen E. Wotring}

Dean of Learning

Science \& Health Professions

February, 2005 - present

\author{
Lord Fairfax Community College \\ Middletown, VA 22645
}

- Leadership of science, health/physical education, and health professions course offerings, degree and certificate programs for the Middletown and Fauquier campuses and college off-campus centers; recruit, develop, and evaluate faculty, assure programs maintain accreditation standards, manage program application processes, schedule classes, develop new clinical opportunities, manage budgets, advise students, coordinate course assessment and program reviews. Programs include associate degrees in Dental Hygiene, Nursing, and Science; certificates in Practical Nursing, Surgical Technology, and Emergency Medicine Technology, and curriculum tracks for Pharmacogenomics transfer and Nurse Aide.

- Responsible for other academic areas through several organizational changes, including Administrative Support Technology, Business, Engineering, and Information Systems Technology.

- Develop new curricula, articulation agreements, and dual enrollment offerings to address needs of students and area employers

- Develop funding sources (grants, donors, corporate sponsors) to meet student scholarship, faculty support, and equipment/building needs for the division

- Participate in College administrative responsibilities

Coordinator of Health Professions

July, 2003 - February, 2005

\section{Lord Fairfax Community College Middletown, VA 22645}

- Leadership of health professions degree and certificate programs at both the Middletown and Fauquier campus; recruit, develop, and evaluate faculty, assure programs maintain accreditation standards, manage program application processes, schedule classes, coordinate clinical opportunities, manage budgets, advise students. Programs include Nurse Aide, Practical Nursing, Associate Degree Nursing, Dental Hygiene, Surgical Technology, and Emergency Medicine Technology.

- Represent health professions in the marketing and strategic planning processes for the College

- Coordinate the expansion of existing programs and establishment of new programs; expansion of ADN program to the Fauquier Campus approved by Virginia Board of Nursing 11/03

- Work with Instructional Leadership Team to assure student access to all required supporting courses and services

- Participate in College administrative responsibilities 
Chief Nursing Officer

October, 1989 - July, 2003
City Hospital, Inc.

Martinsburg, WV 25401

- Leadership of Nursing Service (15 departments, 360 FTE's) for 260-licensed-bed JCAHO accredited full-service community hospital; ADC 100; ED visits 33,000; births 800 ; net revenue $\$ 70$ million annually

- Nurse recruitment/retention averaging vacancy rate $<8 \%$; collaboration with affiliated educational programs; health career development outreach in community elementary and secondary schools

- Installation of the organization's first computerized order communication system, followed by system change to different vendor and initiation of electronic medical record

- Delineation of clinical specialties within medical-surgical units; construction of new surgical wing and major emergency addition

- Implementation of 19-bed hospital-based skilled nursing facility; serve as Licensed Nursing Home Administrator for unit

- Significant role in hospital-wide performance improvement program, implementation of case management service, development of disaster response plans including weapons of mass destruction and smallpox vaccination

Consultant

$1991-2000$
Quorum Health Resources Brentwood, TN 37027

- Consultation site visits in preparation for JCAHO surveys in clinical acute care, clinical support services, and long term care; nursing service productivity; and operational assessments

- Development of reference policy/procedure manuals for nursing administration and surgical services, and JCAHO survey preparation tools for long term care

Assistant Director of Nursing

to Assistant Administrator

September, 1984 - October, 1989
Prince George's Hospital Center

Cheverly, MD 20785

- Various assignments as $\mathrm{ADN}$, including nursing systems, education, outpatient clinics, critical care, and other services for 485-bed JCAHO accredited tertiary trauma center

- Promoted to position coordinating nursing issues across hospital product-line organization. Major involvement with several collective bargaining units

- Promoted to Assistant Administrator, responsible for hospital division including Medical Records, Utilization Review, Quality Assurance, Risk Management, Infection Control, Volunteers, Escort Service, and Hospital Education 
Staff Development Instructor

August, 1980 - September, 1984
Prince George's Hospital Center

Cheverly, MD 20785

- Orientation and continuing education for all levels of nursing staff in assigned clinical specialties, including medical, surgical, and dialysis

- Customized strategies implemented for international travel nurses, new practical nursing graduates, and temporary staff during six-week nurses strike

Assistant Professor of Nursing

September, 1978 - August, 1980

\section{Jacksonville State University \\ Jacksonville, AL}

- Classroom and clinical instruction for BSN students in pediatrics, medicalsurgical, and critical care nursing

- Implementation of computer-assisted instruction for the College of Nursing

\section{Staff Nurse}

July 1976 - September, 1984

- Full and part-time work in medical-surgical, critical care, coronary care, and open heart recovery, in a variety of institutions.

\section{Education}

University of Florida, BSN, 1976

University of Alabama in Birmingham, MSN, 1978

Catholic University of America, DNSc, ABD, 1981-1984

Old Dominion University, $\mathrm{PhD}$ program, Community College Leadership, 2004-present 


\section{Professional Activities}

Affiliate Faculty, College of Nursing and Health Sciences, George Mason University American Association of Critical Care Nurses

Research Committee, 1983-1985

Outcome Standards Task Force, 1988-1990

American Organization for Associate Degree Nursing

American Organization of Nurse Executives

Eastern Panhandle Mental Health Center Board of Directors, Martinsburg, WV, 1992-1998

President, 1997-1998

Various committees

Sigma Theta Tau Nursing Honor Society

Virginia Council of Associate Degree Nursing

\section{Awards, Certification and Licensure}

Executive of the Year, Shenandoah Valley Chapter, International Association of Administrative Professionals, 2007

Distinguished Administrator Award, Lord Fairfax Community College, 2006

Quorum Health Resources Nurse Executive of the Year, Northeast Division, 1993

Certified, Nursing Administration, Advanced, American Nurses Credentialing Center, 1997-2007.

Licensed Registered Professional Nurse, Maryland, Virginia, West Virginia

\section{Publications and Presentations}

Ackerman, S., Bernsteiner, J., Kuhn, R., Turzan, L., Tyler, M., and Wotring, K. E. (1990). Outcome Standards for Nursing Care of the Critically Ill. Newport Beach, CA: American Association of Critical Care Nurses.

Ackerman, S., Bernsteiner, J., Kuhn, R., and Wotring, K. E. (1991, May). AACN Outcome Standards. Presented at the National Teaching Institute of the American Association of Critical Care Nurses, San Francisco, CA.

Bol, L., \& Wotring, K. E. Generational differences in community college students' perceptions of cheating. Proposal submitted to the Annual Meeting for the American Educational Research Association, New York. 
Wotring, K. E. (1978). Problems in management: Diabetes in the psychiatric patient. Journal of Psychiatric and Mental Health Services, 16(8), 26-28.

Wotring, K. E. (1979). Adult respiratory distress syndrome as a complication of pregnancy. Journal of Maternal Child Nursing, 4(5), 314-317.

Wotring, K. E. (2001, October). Addressing workforce management challenges that impact patient safety: Nursing service role enhancements in a community hospital. Presented at the National Patient Safety Symposium, Dallas, TX.

Wotring, K. E. (2006, April). Enhancing academic integrity in a multi-generational student body. Presented at the New Horizons Conference of the Virginia Community College System, Roanoke, VA.

Wotring, K. E. (2007). Cheating in the community college: generational differences among students and implications for faculty. Inquiry: The Journal of the Virginia Community College System, 12(1), 5-13. 